\title{
Slip history of the La Cruz fault: development of a late Miocene transform in response to increased rift obliquity in the northern Gulf of California
}

Scott E.K. Bennett ${ }^{1,2}$, Michael E. Oskin ${ }^{1}$, Alexander Iriondo ${ }^{3,4}$, Michael J. Kunk ${ }^{5}$

1-Department of Earth and Planetary Sciences, University of California-Davis, 2119 Earth and Physical Sciences, One Shields Avenue, Davis, California 95616, USA

2-U.S. Geological Survey, Department of Earth and Space Sciences, University of Washington, Box 351312, Seattle, Washington 98195, USA.

3-Centro de Geociencias, Universidad Nacional Autónoma de México, Campus Juriquilla, C.P. 76230 Juriquilla, Querétaro, México

4-The University of Texas at Austin, Jackson School of Geosciences, 2305 Speedway, Stop C1160, Austin, Texas 78712, USA

5-U.S. Geological Survey, 12201 Sunrise Valley Drive, MS-926A, Reston, Virginia 20192-0002, USA

Bennett et al. - La Cruz fault manuscript (Tectonophysics Special Issue) 


\section{ABSTRACT}

The Gulf of California rift has accommodated oblique divergence of the Pacific and North America plates in northwestern México since Miocene time. Due to its infancy, its rifted margins preserve a rare onshore record of early continental break-up processes and an opportunity to investigate the role of rift obliquity in strain localization. We map rift-related structures and syn-tectonic basins on southern Isla Tiburón, a proximal onshore exposure of the rifted North America margin. We integrate analysis and geochronology of syn-tectonic sedimentary basins and mapping of crosscutting relationships to characterize the style and timing of fault activity. On southern Isla Tiburón, an early phase of extension initiated between $19-17 \mathrm{Ma}$ and $12.2 \mathrm{Ma}$. Subsequently, these normal faults and related basins were cut by the La Cruz strike-slip fault and buried by deposits of the La Cruz basin, an elongate, fault-controlled trough coextensive with the La Cruz fault. Crosscutting relationships show that the NW-striking La Cruz fault accrued $5 \pm 2 \mathrm{~km}$ of dextral slip $\sim 8-4 \mathrm{Ma}$. The La Cruz fault and parallel Tiburón transform were kinematically linked to detachment faulting that accommodated latest Miocene to Pliocene oblique opening of the offshore Upper Tiburón pull-apart basin. The onset of strike-slip faulting on Isla Tiburón was synchronous with the $\sim 8-6$ Ma onset of transform faulting and basin formation along $>1,000 \mathrm{~km}$ of the reconstructed Pacific-North America plate boundary. This transition coincides with the commencement of a clockwise azimuthal shift in Pacific-North America relative plate motion that increased the obliquity of the Gulf of California rift and formed the Gulf of California shear zone. The record from the proto-Gulf of California illustrates how highly oblique rift geometries, where transform faults are kinematically linked to pull-apart basins, 
enhance the ability of continental lithosphere to rupture and, ultimately, hasten the formation of new oceanic rift basins.

Keywords: Gulf of California; oblique continental rifting; transtension; Isla Tiburón; La Cruz fault; Gulf of California shear zone

\section{INTRODUCTION}

Continental rifts require focused strain to successfully rupture continental lithosphere and form new ocean basins (Buck, 1991). Rift localization may occur via a variety of processes, such as (1) lithospheric necking (Buck, 1991, Lavier and Manatschal, 2006), (2) heating and magmatism from asthenospheric upwelling (Kusznir and Park, 1987; Hopper and Buck, 1996; Buck et al., 1999), (3) formation of large-offset, trans-lithospheric detachment faults (Tucholke et al., 1998; Lavier and Manatschal, 2006), (4) thermal weakening beneath thick rift sedimentation (Lavier and Steckler, 1997; Bialas and Buck, 2009), or (5) an increase in extensional strain rate (England, 1983; Kusznir and Park, 1987; Bassi, 1995; Huismans and Beaumont, 2003). Analogue modeling studies (e.g. Bonini et al., 1997; Corti et al., 2001) and fully three-dimensional numerical modeling (van Wijk, 2007; Brune et al., 2012; Heine and Brune, 2014) of rifting indicates that the degree of rift obliquity may also enhance localization. Highly oblique rifts (a small angle between plate boundary and relative plate motion) accommodate a significant component of deformation on transform (strike-slip) structures (Withjack and Jamison, 1986), which tend to remain more localized (Chester, 
1995) than normal faults (Buck, 1991, Forsyth, 1992), and may catalyze continental rupture along linked pull-apart basins (van Wijk, 2007; Bennett, 2011).

Testing the role of obliquity in rift localization requires knowledge of the spatiotemporal history of deformation, and particularly the timing of transform fault formation and activity. Such records are readily accessible in sedimentary basins formed along or adjacent to strike-slip faults that preserve a signature of fault activity in their architecture, subsidence history, sediment provenance, and facies relationships (Christie-Blick and Biddle, 1985; Ingersoll, 1988; Xie and Heller, 2009).

The nascent Gulf of California rift is an active oblique rift (Lonsdale, 1989) where strain localization (Oskin et al., 2001; Oskin and Stock, 2003b), marine basin formation (Oskin and Stock, 2003a; Bennett et al., 2015), and continental rupture (Lizarralde et al., 2007; Martín-Barajas et al., 2013) have each recently occurred, thereby preserving a fresh geologic record from which to investigate the role of plate boundary obliquity in rift localization. The Gulf of California rift has developed within the western part of the Mexican Basin and Range Province, a diffuse continental extensional province that initiated within the Sierra Madre Occidental (Fig. 1 inset) during Oligocene time ( 25-30 Ma; Gans, 1997; Henry and Aranda-Gomez, 1992; González-León et al., 2012; Ferrari et al., 2013) and generally expanded westward as the subduction-related volcanic arc migrated westward (McDowell et al., 1997; Gans, 2006). With the southeastward passing of the Rivera triple junction ca. 12.3 Ma (chron 5a of Atwater and Stock, 1998), the plate tectonic setting evolved from subduction and back-arc extension to a broad region of integrated transtensional dextral shearing between the Pacific and North America plates both east and west of the stable Baja California microplate (Gans, 1997; Fletcher et al., 
2007). This transtensional strain was accommodated across a heterogeneous, incompletely documented system of dextral, normal, and oblique-slip faults kinematically linked to the southern San Andreas fault system in southern California. During latest Miocene time, this diffuse deformation began to coalesce into the Gulf of California shear zone (Bennett and Oskin, 2014), a narrow NNW-trending belt of localized strikeslip faulting, clockwise block rotation, and subsiding pull-apart basins that broadly coincided with early to middle Miocene volcanism. By the end of the late Miocene (ca. 6 Ma), Pacific-North America (PAC-NAM) plate motion had become largely $(\geq 90 \%)$ localized into the Gulf of California (Oskin et al., 2001; Oskin and Stock, 2003b; Umhoefer, 2011).

Regional models for the post-12.3 Ma tectonic evolution of the PAC-NAM plate boundary provide variable estimates for the onset, magnitude, and location of earliest dextral deformation. Early geologic studies and global plate circuit models (Stock and Hodges, 1989; Atwater and Stock, 1998) invoke little to no dextral faulting within the Gulf of California region east of the Baja California microplate (Fig. 1 inset) prior to $\sim 6$ Ma, a period loosely referred to as the proto-Gulf of California (Karig and Jensky, 1972). In contrast, other tectonic models invoke significant magnitudes $(150-250 \mathrm{~km})$ of dextral deformation within the Gulf of California during the proto-Gulf time period (e.g. Gans, 1997; Fletcher et al., 2007; Seiler et al., 2012). Importantly, restorations of correlative cross-Gulf Miocene ignimbrites (Fig. 1; Oskin et al., 2001; Oskin and Stock, 2003b) require that the NW-SE dextral-oblique divergence between the modern shorelines of the northern Gulf of California occurred largely after $\sim 6.4-6.1 \mathrm{Ma}$. Thus, any substantial pre6 Ma dextral deformation related to the PAC-NAM plate boundary may be preserved on 
the fringes of the modern Gulf of California basin, within the rifted continental margins of eastern Baja California or western Sonora and Sinaloa.

Recent studies of the rifted continental margins of the Gulf of California (Fig. 1) document evidence of significant dextral deformation during proto-Gulf time (Seiler et al., 2012; Bennett et al. 2013; Herman, 2013; Bennett and Oskin, 2014). Timing constraints from these flanking regions suggest that the majority of this dextral deformation and related basin formation post-dates $\sim 8 \mathrm{Ma}$, a few million years after the 12.3 Ma plate tectonic reorganization that formed the dextral-oblique PAC-NAM plate boundary at the latitude of the Gulf of California (Stock and Molnar, 1988). Currently, it is not well understood if this apparent delay indicates an evolution to a more oblique rifting phase, or alternatively, that dextral deformation during proto-Gulf time was ubiquitous throughout the Mexican Basin and Range extensional province and remains to be fully documented. Consequently, it is unclear what role dextral faulting may have played in focusing a broad region of continental extension into a localized rift that led to the formation of the Gulf of California ocean basin.

In this paper, we report the results of an integrated stratigraphic, structural, and geochronologic study of the La Cruz strike-slip fault zone and related sedimentary basins exposed on southern Isla Tiburón, a large $\left(1,200 \mathrm{~km}^{2}\right)$ island in the Gulf of California (Fig. 1) that constitutes the outboard, exposed edge of the Sonora (North America) rifted margin. We incorporate our results with previous findings from coastal Sonora and the conjugate rift margin in northeastern Baja California to synthesize the tectonic evolution of the northern Gulf of California, and draw connections to similar activity documented in the Salton Trough and southern Gulf of California. We document an early phase of 
normal faulting and related extensional basin formation on southern Isla Tiburón that initiated sometime after $\sim 19-17 \mathrm{Ma}$ and was active by $\sim 12.2 \mathrm{Ma}$. The La Cruz strike-slip fault crosscuts older normal faults and related basin deposits. From constraining the age of syn-tectonic deposits of the La Cruz basin, we find that the La Cruz fault became active $\sim 8-7$ Ma. Dextral strike-slip faulting and basin sediment accumulation ceased by 4 Ma. Latest Miocene onset of dextral-oblique strike-slip faulting and related basin formation on southern Isla Tiburón is regionally consistent with the onset of transtensional deformation throughout the Gulf of California and Salton Trough. This supports the contention that increasing obliquity of PAC-NAM plate motion triggered a regional-scale reorganization of faulting within the proto-Gulf of California, leading to formation of major transform faults and development of the Gulf of California shear zone, a belt of transrotational deformation and basin formation within the western portion of the Mexican Basin and Range Province. The development of focused transtensional strain facilitated subsequent rift localization and formation of the Gulf of California ocean basin.

\section{TECTONIC SETTING}

\subsection{Gulf of California}

Formation of the Gulf of California occurred due to oblique-divergent separation of the Pacific and North America plates (Hamilton, 1961; Larson et al., 1968; Lonsdale, 1989; Fenby and Gastil, 1991), which initiated along the length of the Baja California peninsula ca. 12.3 Ma (Fig. 1 inset; Atwater and Stock, 1998). Evidence for the earliest dextral-oblique deformation east of Baja California is documented onshore across a broad zone of transtensional deformation, now preserved as inactive faults and exhumed non- 
marine tectonic basins within the continental margins of Baja California (Lewis and Stock, 1998a; Seiler et al., 2010) and Sonora (Bennett et al., 2013). A marine embayment formed at the mouth of the Gulf of California ca. 8.5-8 Ma (Carreño, 1992; Molina-Cruz, 1994; McCloy et al., 1988) and flooded northward to the central Gulf of California by $~ 7$ Ma (Holt et al., 2000; Miller and Lizarralde, 2013) through transtensional basins related to oblique rifting (Skinner et al., 2012).

By 6.4-6.1 Ma, rifting became localized within the core of this early-formed transtensional belt (Oskin et al., 2001; Oskin and Stock, 2003b). At 6.3 Ma, coeval with localization of the plate boundary (Oskin and Stock, 2003a), the Gulf of California seaway flooded northward into the northern Gulf of California and the Salton Trough (e.g. Escalona-Alcázar et al., 2001; Pacheco et al., 2006; Dorsey et al., 2011; Bennett et al., 2015). Large marine depocenters, which contain thick (>4 km) sequences of marine sediments (González-Fernández et al., 2005; Pacheco et al., 2006), developed within a NNW-trending belt of en echelon pull-apart basins, now located in the eastern part of the modern-day Gulf of California (Fig. 1; Aragón-Arreola and Martín-Barajas, 2007).

By late Pliocene time ( 3.3-2.0 Ma), transtensional strain in the northern Gulf of California migrated to the west (Aragón-Arreola and Martín-Barajas, 2007), abandoning the eastern marine basins and initiating new marine pull-apart basins (see also Lonsdale, 1989). This westernmost system of transtensional structures remains as the primary PACNAM plate boundary where modern-day oblique plate motion is accommodated along a system of long, NW-striking, right-stepping, en echelon, transform faults connected by short ( $\leq 50 \mathrm{~km}$-wide), NW-SE-extending, pull-apart basins. Oblique rift basins in the southern Gulf of California have proceeded to seafloor spreading (Fig. 1 inset; Larson et 
al., 1968; Lonsdale, 1989; Fenby and Gastil, 1991; Kluesner, 2011), while these pullapart basins in the northern Gulf of California and Salton Trough have formed new hybrid crust of basalt and sediments (Fuis et al., 1984; Dorsey, 2010; Martín-Barajas et al., 2013).

\subsection{Sonora (North America) Margin}

In the northern Gulf of California, the largely submerged Sonora continental margin serves as the western, rifted edge of North America continental crust (Fig. 1). Here, detailed offshore seismic-reflection studies (Mar-Hernández et al., 2012; MartínBarajas et al., 2013) demonstrate that the irregular edge of the margin is structurally controlled by a system of NW-striking en echelon dextral-oblique transform faults kinematically linked to major N-striking normal faults (Fig. 1). These transform faults serve as the northeastern edges of deep rhomboid-shaped marine pull-apart basins, which together accommodated oblique plate boundary motion via NW-SE-directed extension. These structures and basins form a right-stepping series of NW-SE-elongate structural rift segments, including from NW to SE: (1) Salton Trough-Altar, (2) Wagner-ConsagAdair-Tepoca, (3) Upper Delfín-Upper Tiburón, and (4) Lower Delfín-Lower TiburónYaqui rift segments (Fig. 1).

The time-space history of tectonic activity in these pull-apart basins indicates that the southeastern reaches of transform faults were likely active during the early development of the Gulf of California rift (Oskin and Stock, 2003b; Aragón-Arreola and Martín-Barajas, 2007). At the latitude of Isla Tiburón, the Tiburón transform and De Mar fault are NW-striking dextral-oblique faults that bound the Upper Delfín-Upper Tiburón rift segment (Fig. 1; Mar-Hernández et al., 2012). These structures appear to continue to 
the southeast onto Isla Tiburón and within the Sonora continental margin (Gastil and Krummenacher, 1977a, b; Oskin, 2002; Aragón-Arreola et al., 2005). These transform fault zones each exceeds multiple tens of kilometers, suggesting they were significant, plate boundary-scale structures prior to rift localization.

The offshore Tiburón transform fault and the La Cruz fault, a strike-slip fault mapped parallel to the Tiburón transform across southern Isla Tiburón, bound the southwestern edge of the Upper Delfín-Upper Tiburón rift segment (Figs. 1 and 2; Gastil and Krummenacher, 1977a; Lonsdale, 1989; Fenby and Gastil, 1991; Oskin, 2002; Oskin and Stock, 2003a,b; Bennett et al., 2015). Both faults continue offshore $\sim 150 \mathrm{~km}$ southeast of the island (Fenby and Gastil, 1991; Aragón-Arreola et al., 2005). Although the Tiburón transform is the primary structure along the southwestern edge of this rift segment, the La Cruz fault is considered to be a less significant, but related dextral fault (Oskin and Stock, 2003a,b). Thick sequences of middle Miocene volcanic rocks do not appear to correlate across the La Cruz fault, suggesting large amounts $(\geq 28 \mathrm{~km})$ of dextral and/or normal displacement (Oskin and Stock, 2003b). The oldest rocks known to correlate across the La Cruz fault are late Miocene (6.4-6.0 Ma) marine deposits (Fig. 2), which display no more than $1 \mathrm{~km}$ of dextral displacement (Bennett et al., 2015). This suggests that most of the fault activity on the La Cruz fault occurred prior to rift localization at ca. $6 \mathrm{Ma}$. Thus, the La Cruz fault preserves a detailed record of how strikeslip faulting developed and evolved during the early stages of oblique rifting in northwestern México.

\section{METHODS}




\subsection{Geologic, Structural, and Stratigraphic Mapping}

Building upon reconnaissance work by Gastil and Krummenacher (1977a) and Oskin (2002) (Fig. 2), we present geologic mapping (Fig. 3) and analysis of the La Cruz dextral fault where it is exposed across southern Isla Tiburón. This fault divides southern Isla Tiburón into two structural domains: the Sauzal domain to the northeast, and the La Cruz domain to the southwest (Fig. 2). We also document well-exposed sedimentary basins (Fig. 4) that are adjacent and intimately related to faulting and record fault-related subsidence and deformation. Similar structural and stratigraphic examination of strikeslip basins in southern California and northwestern México has been used to reconstruct the history of transform motion across transpressional (e.g. Crowell, 1974; Powell and Weldon, 1992) and transtensional (e.g. Powell and Weldon, 1992; Axen and Fletcher, 1998; Martín-Barajas et al., 2001; Pacheco et al., 2006) portions of the dextral PACNAM plate boundary. Our structural measurements include brittle-fault orientations and kinematic indicators such as fault striae preserved on polished fault planes (Fig. 3). Mapping was conducted at 1:10,000-scale on 0.6 m-resolution, pan-sharpened Quickbird satellite imagery with topographic contours derived from the 90-m Shuttle Radar Topography Mission digital elevation model, similar to Bennett et al. (2015).

\subsection{Geochronology}

We conducted U/Pb (zircon) and Ar/Ar (k-feldspar and volcanic matrix) analysis on samples of volcanic units to provide age constraints for faulting and related basin formation along the La Cruz fault. Dated units include deformed volcanic units that underlie and are interbedded within basin deposits, as well as undeformed volcanic units that cap these basin deposits (Figs. 5, 6, and 7). Samples consisted of 2-5 kg of fresh rock 
collected from representative, in-place outcrops and were processed as described by Bennett et al. (2015). We incorporate our geochronologic results with all published ages across southern Isla Tiburón (Fig. 8; Table 4).

\section{STRATIGRAPHY AND GEOCHRONOLOGY}

\subsection{Pre-Cenozoic Rocks}

Pre-Cambrian to Cambrian basement rocks (Gastil and Krummenacher, 1977b) exposed on southern Isla Tiburón consist of metamorphic units (e.g., slate, quartzite, and phyllite) that are observed only southwest of the La Cruz fault and east of Arroyo Sauzal, including the adjacent small islands of Isla Dátil and Isla Cholludo (Fig. 3). Plutonic rocks intrude these metamorphic units and consist entirely of tonalite and related, typically felsic, dikes that are $90-86$ Ma (Niño-Estrada et al., 2014). We observe tonalite in several La Cruz domain tilt blocks and in one previously undocumented locality in the Sauzal domain (Fig. 3). These plutonic rocks are similar in age and composition to Late Cretaceous ( $\sim 90-80 \mathrm{Ma})$ plutonic rocks on northern Isla Tiburón (Gastil and Krummenacher, 1977b; Schaaf et al., 1999; Niño-Estrada et al., 2014) and along the adjacent Sonora coastline (Gastil and Krummenacher, 1977b; Valencia-Moreno et al., 2003; Ramos-Velázquez et al., 2008).

\subsection{Early to Middle Miocene Volcanic and Sedimentary Rocks}

A thick sequence of volcanic and sedimentary rocks of early to middle Miocene age nonconformably overlies basement and plutonic rocks on southern Isla Tiburón (Figs. 3 and 4). These units are heterogeneous along strike and appear to be broadly concentrated into three compositionally diverse volcanic sub-sequences that are interstratified over large distances: basaltic units in the west, andesitic and dacitic units to 
the north, and rhyolitic units to the southeast (Fig. 3). Previous studies on southwestern Isla Tiburón document early to middle Miocene volcanic and sedimentary units of different lithology and age juxtaposed across the La Cruz fault (Gastil and Krummenacher, 1977a; Neuhaus, 1989; Gastil et al., 1999; Oskin, 2002; Oskin and Stock, 2003a; Bennett et al., 2015), a pattern that persists along the entire fault trace (Fig. 3; Gastil and Krummenacher, 1977a; this study). We summarize this volcanic and sedimentary sequence spatially from west to east, within both the La Cruz and Sauzal domains.

\subsubsection{La Cruz Domain}

In the La Cruz domain from the western tip of the island to Hast Hinamj (sometimes referred to as Cerro Colorado), the early to middle Miocene sequence consists of red volcaniclastic sandstone (Tvsl), basalt flows and breccias (Tb) (Fig. 9A), and lacustrine limestone (Tsr) (Neuhaus, 1989; Gastil et al., 1999; Bennett et al., 2015; this study). These are conformably overlain by additional basaltic- and dacitic-andesite lava flows and breccias (Tba and Tda) (Fig. 3 and 10A). Most volcanic units here range in age from 23-15 Ma (Fig. 3; Gastil and Krummenacher, 1977b; Neuhaus, 1989; Gastil et al., 1999). Beneath Hast Hinamj and east towards the Arroyo Sauzal drainage, units consist of basalt flows and breccias $(T b)$ with occasional interbedded red volcaniclastic sandstone (Tvsl) conformably overlain by an andesite lava flow (Tha) (Figs. 3 and 10B).

East of the Arroyo Sauzal drainage, the interbedded basalt $(T b)$ and red volcaniclastic sandstone $(T v s l)$ persist at the base of the Miocene section. Gastil and Krummenacher (1977b) report a K-Ar (whole rock) age of $7.0 \pm 0.3$ Ma from a thick sequence of basalt just east of Arroyo Sauzal (Fig. 3). However, our detailed mapping 
indicates that this sample location is among early Miocene basalt flows $(T b)$, suggesting that the sample was either mislocated on their map (correct location is likely $\sim 1 \mathrm{~km}$ farther to the east-southeast) or the K-Ar age is erroneously young. Basal basalt flows $(T b)$ and volcaniclastic sandstone and conglomerate (Tvsl) units gradually thin to the east where they are conformably overlain by thick deposits of red volcaniclastic sandstone $(T v s)$. Farther to the east, in the footwall of the Hihitiij fault, the basal basalt flows $(T b)$ pinch out and this relatively younger red volcaniclastic sandstone (Tvs) rests directly upon basement and plutonic rocks (Figs. 3 and 10D). Tvs is conformably overlain by another andesite flow (Tal), distinct in lithology and location from andesite units mapped to the west.

East of Arroyo de La Cruz, units of this sequence include a volcaniclastic breccia $(T v b)$ and volcaniclastic conglomerate $(T v c)$ locally mapped near the southeastern corner of Isla Tiburón (Fig. 3). We assign these units to the early to middle Miocene sequence, but these units are mapped only in fault contact with more widespread units and thus their relative age is unknown.

\subsubsection{Sauzal Domain}

In the Sauzal domain, northeast of the La Cruz fault, units from this early to middle Miocene sequence exposed west of Hipat Mesa consist of interbedded monolithologic volcaniclastic breccia $(T b x v)$, dacite flows $(T d)$, and dacitic breccia $(T b x d)$ and range in age from 19-11 Ma (Fig. 3; Smith et al., 1985; Neuhaus, 1989; Gastil et al., 1999; Oskin and Stock, 2003a; Bennett et al., 2015). Units from this sequence continue beneath and east of Hipat Mesa. Between Hipat Mesa and the Sauzal fault, the oldest units in this sequence consist of monolithologic volcaniclastic breccia (Tbxv) 
conformably overlain by laterally discontinuous dacite $(T d)$ and andesite flows (Tah) (Figs. 3, 10B, and 10E).

East of the Sauzal fault and towards Arroyo de La Cruz, units of this sequence are notably distinct from those west of this structure. Here, the oldest exposed units in this sequence consist of a thick stack of andesite flows (Tha-r,Tha) with a rare, discontinuous rhyolite flow $(\operatorname{Tr})$. These flows are conformably overlain by interbedded deposits of redgray, andesitic breccia and volcaniclastic sandstone and conglomerate $(\operatorname{Tr} b)$, basalt flows $(T b)$, additional andesite flows (Tha-r, Tha), and stratified deposits of red volcaniclastic sandstone and white lacustrine limestone (Tsr) (Figs. 3, 10C, 10D, and 10E). We report a new ${ }^{40} \mathrm{Ar} /{ }^{39} \mathrm{Ar}$ (volcanic matrix, isochron) age of $20.68 \pm 0.20 \mathrm{Ma}$ from exposures of Tha $<1 \mathrm{~km}$ northeast of the La Cruz fault (Fig. 5A; Table 1).

East of Arroyo de La Cruz, units of this sequence consist of interbedded dacite breccia (Tdb), andesite flows (Ta), and andesitic basalt flows (Tab) (Fig. 3). We assign these units to the early to middle Miocene sequence, though their relative age is unknown due to younger conglomerate and alluvial deposits that conceal their relationship with units to the west.

\subsection{Latest(?) Middle Miocene Volcanic and Sedimentary Rocks}

On southern Isla Tiburón, a sequence of latest(?) middle Miocene volcanic and sedimentary rocks overlies the early to middle Miocene sequence (Figs. 3 and 4). These units consist of non-marine sandstone and conglomerate interstratified with an ash-flow tuff and discontinuous, thin ash beds. This relatively younger sequence occurs either conformably overlying the older early to middle Miocene sequence, or above an angular unconformity that separates these two sequences. We summarize this volcanic and 
sedimentary sequence spatially from west to east, within both the La Cruz and Sauzal domains.

\subsubsection{La Cruz Domain}

In the La Cruz domain, perched high beneath the peak of Hast Hinamj (Fig. 9A), units of this sequence overlie older early Miocene basalt $(T b)$ and volcaniclastic sandstone (Tvsl) above an angular unconformity (Figs. 3 and 10A). Here, these overlying units consist of non-marine conglomerate (Tcgl) with up to $\sim 45 \mathrm{~m}$ of an interbedded ashflow tuff (Ttsf). Discontinuous white and yellow ash beds are intercalated within conglomerate deposits immediately above Ttsf. Oskin (2002) reports an ${ }^{40} \mathrm{Ar} /{ }^{39} \mathrm{Ar}$ (Kfeldspar, total gas) age of $9.58 \pm 2.66 \mathrm{Ma}$ from the lower of two cooling units in this tuff, a densely welded, crystal- and pumice-rich, ash-flow tuff, which he called the tuffs of Cerro Colorado. We report a new ${ }^{40} \mathrm{Ar} /{ }^{39} \mathrm{Ar}$ (K-feldspar, multiple crystals) age of $12.20 \pm$ $0.05 \mathrm{Ma}$ from the basal vitrophyre of this same ash-flow tuff, $\sim 1.5 \mathrm{~km}$ along strike to the northwest (Fig. 6A; Table 2). Based on its broadly similar lithology and age, we tentatively correlate this tuff with the tuff of San Felipe (Stock et al., 1999), a regionally extensive tuff that blanketed $>4,000 \mathrm{~km}^{2}$ of the Mexican Basin and Range, exposed in Baja California, on Isla Ángel de la Guarda, across western and northern Isla Tiburón, and in coastal and central Sonora (see Stock et al. (2006) and Bennett and Oskin (2014) for summary).

From Arroyo Sauzal to the southeastern corner of Isla Tiburón (Fig. 3), units of this sequence appear to conformably overlie older early to middle Miocene volcaniclastic sandstone (Tvs) (Figs. 9B, 10C, and 10D). The oldest unit of this sequence here is the tuff of Ensenada de La Cruz (Tlc), a densely welded, crystal-rich, ash-flow tuff. Oskin (2002) 
reports an ${ }^{40} \mathrm{Ar} /{ }^{39} \mathrm{Ar}$ (K-feldspar, total gas) age of $11.25 \pm 1.98 \mathrm{Ma}$ for $\mathrm{Tlc}$ exposures immediately west of Ensenada de la Cruz (Fig. 3). We report a new ${ }^{40} \mathrm{Ar} /{ }^{39} \mathrm{Ar}$ (Kfeldspar, multiple crystals) age of $12.21 \pm 0.09 \mathrm{Ma}$ (Fig. 6B; Table 3) from the same strike-ridge of $T l c, \sim 150 \mathrm{~m}$ to the northwest (Fig. 3). Tlc is conformably overlain by a diverse volcanic sequence that consists of the $>400 \mathrm{~m}$-thick rhyolite flows of Punta Amarillo (Trpa1, Trpa2, Trpa3) (Fig. 9C), interfingered with a basaltic andesite unit up to $120 \mathrm{~m}$ thick (Tba), up to $\sim 80 \mathrm{~m}$ of stratified ash and pumice deposits (Tty), and a vesicular basalt flow (Tty-b) (Figs. 10C and 10D). Approximately $2-3 \mathrm{~km}$ east of the Arroyo Sauzal delta (Fig. 3), up to $\sim 40 \mathrm{~m}$ of non-marine conglomerate (Tcgl) and an andesite flow up to $25 \mathrm{~m}$-thick (Ta2), discontinuously overlie deposits of the $\sim 12.2 \mathrm{Ma}$ tuff of Ensenada de La Cruz (Tlc) and the upper flow unit of the rhyolite flows of Punta Amarillo (Trpa3). The lowermost Tcgl beds are conformable with the underlying units (e.g. Tlc), both inclined $31-34^{\circ}$ (Fig. 10C). Conglomerate and sandstone beds within Tcgl are gradually less inclined up-section, with the uppermost Tcgl beds inclined 13$17^{\circ}$, similar to the basal contact of the overlying basalt breccia of Alta Sauzal (Tbas), a vesicular basalt breccia deposit (Fig. 10C).

\subsubsection{Sauzal Domain}

In the Sauzal domain, between Hipat Mesa and the Sauzal fault, units of this sequence unconformably(?) overlie the gently tilted early to middle Miocene volcanic units (e.g. Tbxv, Td, Tah) (Figs. 3, 10B, and 10E). These overlying units consist of volcaniclastic conglomerate $(T c g l)$ and several intercalated, discontinuous volcanic units, including a resistant, brick-red, andesitic block and ash deposit (Tbar), basalt breccias $(T b x b)$, and a welded tuff that we correlate to the tuff of San Felipe (Ttsf). Discontinuous, 
thin, white and yellow airfall ash beds are intercalated within conglomerate deposits immediately above Ttsf (Fig. 3). Here, northeast of the La Cruz fault, we report a new ${ }^{40} \mathrm{Ar} /{ }^{39} \mathrm{Ar}$ (K-feldspar, multiple crystals) age of $12.12 \pm 0.08 \mathrm{Ma}$ from exposures of Ttsf (Fig. 6C; Table 2). This age is $\sim 400$ ka younger than ages obtained from coastal Sonora (Bennett et al., 2013) and central Sonora (Vidal-Solano et al., 2005), but it is consistent with our $12.20 \pm 0.05 \mathrm{Ma}$ age for Ttsf southwest of the La Cruz fault and with the range of reported ages (12.7-12.0 Ma) for Ttsf in northeastern Baja California (Stock, et al., 2008). The true eruption age of the tuff of San Felipe is not settled, and may be biased by contamination from older xenocrystic material liberated from rhyolite inclusions that were partially molten at the time of eruption. Stock et al. (2008) suggest that $\sim 12.3 \mathrm{Ma}$ may represent the most probable age for the tuff of San Felipe. For the purpose of this study, we will use an age of $\sim 12.2$ Ma when referring to the tuff of San Felipe, consistent with our ${ }^{40} \mathrm{Ar} /{ }^{39} \mathrm{Ar}$ ages from southern Isla Tiburón.

East of the Sauzal fault and towards Arroyo de La Cruz, units of this sequence are only locally exposed and overlie older early Miocene volcanic units (e.g. Thf-r, $T h f, T r b$, $T b, T h a)$ above an angular unconformity (Figs. 3 and 10E). These overlying units consist of non-marine conglomerate ( $T c g 1)$ interstratified with limited deposits of the tuff of Ensenada de la Cruz $(T l c)$. In this area, we report two new ${ }^{40} \mathrm{Ar} /{ }^{39} \mathrm{Ar}$ (K-feldspar, multiple crystals) ages for $T l c, 12.14 \pm 0.08 \mathrm{Ma}$ (Fig. 6D; Table 2) from Tlc exposures $\sim 1.5 \mathrm{~km}$ northeast of the La Cruz fault (Fig. 3) and $12.26 \pm 0.07$ Ma (Fig. 6E; Table 2) from steeply titled Tlc exposures within the La Cruz fault zone (Fig. 3). Both ages are consistent with our 12.21 \pm 0.09 Ma isotopic age for Tlc southwest of the La Cruz fault. East of Arroyo de La Cruz, units of this sequence are only exposed at a small, isolated 
mesa-top of sub-horizontal non-marine conglomerate (Tcgl), capped by a 12-15 m-thick densely welded tuff that overlies early to middle Miocene volcanic rocks above an angular unconformity (Fig. 3). From its lithology and stratigraphic position, we tentatively correlate this isolated tuff exposure to the tuff of San Felipe (Ttsf).

\subsection{Late Miocene-Pliocene La Cruz Basin}

Across southern Isla Tiburón, a sequence of volcanic and sedimentary units of the La Cruz basin occur above an angular unconformity cut across both the early to middle Miocene sequence and latest(?) middle Miocene sequence. Outcrops of these La Cruz basin deposits are concentrated along the La Cruz fault (Fig. 3) and consist of non-marine coarse conglomerate and sandstone with intercalated and capping volcanic rocks. We subdivide these deposits into two units, $T c g 2$ and $T c g 3$, which are progressively less deformed up-section. These deposits, with their interbedded volcanic rocks and angular unconformities that separate them, record the history of deformation along the La Cruz strike-slip fault. The overall geometry of the La Cruz basin appears to be controlled by an elongate structural depression (negative flower structure) formed by both vertical fault motion and block tilting down towards the fault (Figs. 10B, 10C, and 10D). In contrast to the older units, La Cruz basin rocks typically are exposed continuously across and along the La Cruz fault (Fig. 3).

\subsubsection{Lower La Cruz Basin}

The lower portion of the La Cruz basin consists of widespread deposits of nonmarine conglomerate and sandstone (Tcg2; Fig. 3). Deposits of Tcg2 overlie an angular unconformity (Fig. 9D), where Tcg2 strata are inclined up to $25^{\circ}$ less steep than underlying units, including Tcgl and Tbas (Figs. 3, 10B, 10C, and 10D). In the La Cruz 
domain $\sim 3 \mathrm{~km}$ east of the Arroyo Sauzal delta, $T c g 2$ overlies the vesicular basalt breccia of Alta Sauzal (Tbas) in angular unconformable contact (Figs. 3 and 10C). Tbas deposits are at least $\sim 90 \mathrm{~m}$ thick but appear to dramatically thin to $<12 \mathrm{~m}$ thick across a northstriking normal fault (Fig. 3). The extent of Tbas deposits appears to be restricted to $\sim 3$ $\mathrm{km}$ along strike. We report a new ${ }^{40} \mathrm{Ar} /{ }^{39} \mathrm{Ar}$ (volcanic matrix, isochron) age of $7.86 \pm 0.33$ Ma on a breccia clast sample collected from this exposure of Tbas (Fig. 5B; Table 1). Within the La Cruz fault zone $\sim 2 \mathrm{~km}$ southeast of Hipat Mesa, a white airfall tuff, up to 5 m thick, is intercalated with $T c g 2$ deposits just above its basal, angular unconformable contact with an early to middle Miocene andesite (Tha) (Figs. 3 and 10B). We report a new $\mathrm{U} / \mathrm{Pb}$ (zircon, multiple crystals) age of $6.87 \pm 0.07 \mathrm{Ma}$ from a sample of this tuff (Fig. 7A; Table 3). Thus, the base of the La Cruz basin is bracketed by these $7.86 \pm 0.33$ Ma and $6.87 \pm 0.07$ Ma volcanic units. $T c g 2$ deposits are likely coeval with deformed, marine strata of broadly similar age ( 6.4-6.0 Ma) near the base of the southwest Isla Tiburón (SWIT) basin, northwest of Hipat Mesa (Bennett et al., 2015). Tcg2 of the La Cruz basin and basal marine deposits of the SWIT basin are not in contact, and may have been sourced from different drainage basins separated by a paleotopographic high that consisted of early to middle Miocene volcanic rock outcrops (e.g., Tbxv, Tbxd) at or just northwest of Hipat Mesa (Fig. 3).

\subsubsection{Upper La Cruz Basin}

The uppermost La Cruz basin fill consists of relatively undeformed sedimentary deposits ( $T c g 3$ ) that straddle the La Cruz fault beneath Hipat Mesa (Figs. 3, 10E, and 10F). Tcg3 overlies and buttresses against the northeastern margin of an undated andesitic-dacite volcano complex (Tdhh; Figs. 3 and 4) whose deposits form the 
topographically prominent peak, Hast Hinamj (Fig. 10A). Non-marine deposits of $T c g 3$ continue to the north and northeast beyond the map area, towards the Valle de Tecomate (Fig. 2; Oskin, 2002). These $T c g 3$ deposits also continue northwest of Hipat Mesa into the SWIT basin (Fig. 3), where they grade laterally (down-dip) into a relatively undeformed Gilbert-type fan delta system of 6-4 Ma marine foreset and bottom set deposits (Bennett et al., 2015). Based upon the architecture of non-marine and marine strata across southern Isla Tiburón, it appears that these basin marine rocks were sourced from a fluvial system that flowed northwest along the axis of La Cruz basin, straddling the La Cruz fault zone.

\subsubsection{Basin-Capping Deposits}

The La Cruz basin is capped by sub-horizontal deposits of the tuffs of Hipat Mesa (Tthm) (Fig. 3) that form a prominent $\sim 20 \mathrm{~km}^{2}$ tableland (Fig. 9E,F). Deposits of Tthm consist of three, distinct, crystal-poor, ash and pumice units (Tthm1, Tthm2, Tthm3). Tthm deposits are horizontal everywhere, except near the northeastern flank of Hast Hinamj (Fig. 9F), where ash and pumice beds are locally inclined up to the west and onlap the toe of the andesitic-dacitic volcanic complex at Hast Hinamj (Tdhh). The Hast Hinamj volcano may have been the source of the tuffs of Hipat Mesa. We report a new $\mathrm{U} / \mathrm{Pb}$ (zircon, multiple crystals) age of $4.37 \pm 0.08$ Ma from a sample of this tuff (Fig. 7B; Table 3). This age is broadly similar to a $\sim 3.5-4.1$ Ma flat-lying rhyodacite flow observed at a similar capping stratigraphic position and topographic elevation at Hast Pitzcal (Cerro Starship), 7 km northwest of Hipat Mesa (Bennett et al., 2015). Our 4.37 $\pm 0.08 \mathrm{Ma}$ age for Tthm at Hipat Mesa is almost identical to the $4.34 \pm 0.20 \mathrm{Ma}$ age for Tthm that Bennett et al. (2015) reported at the western shoreline of Isla Tiburón, $7.5 \mathrm{~km}$ 
northwest of Hipat Mesa (Fig. 3). No other deposits are observed above these $44.4-3.5$ Ma capping volcanic units. Thus, Tthm provides a minimum age constraint for deposition within the La Cruz basin (and SWIT basin) on southern Isla Tiburón.

\section{FAULTING AND FOLDING}

Numerous late Cenozoic structures deform rocks on southern Isla Tiburón. The intensity of deformation and tilting is greatest within the early to middle Miocene volcanic and sedimentary sequence (Fig. 3 stereonets), which is deformed by thrust faults and folds, normal faults, and strike-slip faults. La Cruz basin deposits (e.g. Tcg2), which overlie older strata across a significant, widespread angular unconformity, display relatively less deformation (Fig. 3, map and stereonets), bury older structures (Figs. 3 and 10), and are cut by structures related to strike-slip faulting. The youngest La Cruz basin sedimentary deposits (e.g. Tcg3) and basin-capping volcanic units (e.g. Tthm) display very little to no deformation.

\subsection{La Cruz Fault}

The La Cruz fault is a significant, NW-striking, sub-vertical, dextral strike-slip fault zone that transects the entire width of southern Isla Tiburón (Gastil and Krummenacher, 1977a), parallel to the offshore dextral Tiburón transform fault (Figs. 1 and 2). All sub-parallel splays of the La Cruz fault deform late Miocene and older map units, commonly juxtaposing early to middle Miocene volcanic and sedimentary units (e.g. Tha) against latest Miocene non-marine conglomerate (Tcg2) (Fig. 3). Small-offset brittle faults with sub-horizontal (strike-slip) slickenlines oriented parallel to strands of the La Cruz fault are observed in all pre-Quaternary units (Fig. 3), including subtle deformation of the capping tuffs of Hipat Mesa (Tthm). Several restraining bends and 
restraining stepovers occur along the La Cruz fault, and correspond with shortwavelength folds, subsidiary thrust faults, and local rotated blocks. Northwest of Hipat Mesa, internal tuff stratigraphy within Tthm is offset vertically $\sim 2-4$ meters across the primary northwest-striking branch of the La Cruz fault and the basal contact of the Tthm is vertically offset a few tens of meters across a nearby northwest-dipping normal fault. Adjacent faults and folds do not appear to deform the La Cruz fault.

Although the La Cruz fault primarily is a sub-vertical dextral fault, evidence suggests the fault has accommodated significant down-to-the-northeast dip-slip motion. Relatively deeper structural levels are exposed southwest of the fault where metamorphic and plutonic rocks are common. In contrast, northeast of the fault in the Sauzal domain, plutonic rocks are exposed only in an isolated, fault-bounded block in the southeastern portion of the island (Fig. 3). Fault juxtaposition of disparate early to middle Miocene units across the La Cruz fault thus is likely a result of both dextral strike-slip and normal dip-slip motion. This vertical motion across the fault, along with its negative flower structure, together caused the tectonic subsidence necessary for formation of the elongate, syn-tectonic La Cruz and southwest Isla Tiburón sedimentary basins.

\subsection{Additional Strike-Slip Faults}

Additional strike-slip faults, both dextral and sinistral, deform rocks on southern Isla Tiburón. One notable example is an unnamed, NW-striking, sub-vertical $\left(81^{\circ}\right)$ dextral fault that cuts across the Punta Amarillo headland (Fig. 3). This fault is not observed in the prominent, $200 \mathrm{~m}$-tall Hihitiij sea cliff and thus does not continue much more than $1 \mathrm{~km}$ to the northwest. Total dextral offset on this fault is difficult to assess, as we identified no piercing points, but is likely minimal because similar middle Miocene 
volcanic units occur on both sides of this structure. This structure accommodated $\sim 300 \mathrm{~m}$ of down-to-the-southwest apparent dip-slip displacement (Fig. 10D), which could be the result of dextral-oblique or dextral offset of dipping units. Sinistral strike-slip faults are uncommon overall. Where observed northeast of the La Cruz fault, sinistral faults are ENE-striking, and cut the early to middle Miocene sequence of rocks at high angles to their undulatory contacts. Northeast of the La Cruz fault, one well-exposed sinistral fault dips moderately to the north-northwest $\left(62^{\circ}\right)$ and displays a strong set of sub-horizontal slickenlines (rake of $013^{\circ}$ ). Displacement on this sinistral-oblique normal fault is minor, with $\sim 160 \mathrm{~m}$ of sinistral separation of the $T r b-T b$ contact (Fig. 3).

\subsection{Sauzal Fault}

The Sauzal fault is a significant normal fault (Oskin, 2002; this study) in the Sauzal domain. The fault strikes NE-SW and dips moderately to gently $\left(\sim 30-40^{\circ}\right)$ to the northwest, and has a structurally related half-graben in its hanging wall (Figs. 3 and 10E). Across the Sauzal fault, hanging wall units consisting of middle Miocene non-marine conglomerate $(T c g 1)$ and the $\sim 12.2$ Ma tuff of San Felipe (Ttsf) are juxtaposed against footwall units consisting of andesitic (Thf-r, Thf, Tha-r) and mafic (Tb) lava flows of early to middle Miocene age. We estimate that the Sauzal fault has accommodated $\sim 1.7$ $\mathrm{km}$ of dip-slip displacement by measuring the positions of coeval, but not correlative, tuff deposits: the $\sim 12.2$ Ma tuff of San Felipe in its hanging wall and the $\sim 12.2$ Ma tuff of Ensenada de La Cruz in its footwall (Fig. 10E). However these units may have been emplaced at different paleo-elevations, and the offset could be slightly more or less than $1.7 \mathrm{~km}$. The Sauzal fault appears to be truncated by the dextral La Cruz fault.

\subsection{Colorado Fault}


The Colorado fault is a significant, previously unmapped normal fault in the La Cruz domain (Fig. 3). It strikes NE-SW and dips moderately to gently $\left(\sim 30-40^{\circ}\right)$ to the northwest. Hanging wall units of early Miocene basalt $(\mathrm{Tb})$ and Cretaceous tonalite $(\mathrm{Kt})$ are juxtaposed against Cretaceous tonalite $(K t)$ in the footwall (Fig. 10A). Similar to the Sauzal fault, middle Miocene non-marine conglomerate (Tcg1) and the $\sim 12.2$ Ma tuff of San Felipe (Ttsf) are exposed in the hanging wall of the Colorado fault, preserved within cliffs beneath the resistant dacitic volcano (Tdhh) at Hast Hinamj, 3-4 km northwest the fault (Figs. 3 and 10A). We estimate that the Colorado fault has accommodated $\sim 1.5 \mathrm{~km}$ of dip-slip displacement of the nonconformity between Miocene volcanic rocks and Cretaceous tonalite (Fig. 10A). However, this estimate is loosely constrained due to limited exposure of the nonconformity in the footwall block, where the correlative nonconformity is at high angle to the fault. The hanging wall block is cut by several NNE- to NNW-striking secondary normal faults that structurally duplicate the nonconformity in a fanning fault pattern. These faults do not cut the Colorado fault at the surface and likely merge with the Colorado fault at depth (Fig. 10A). Similar to the Sauzal fault, the Colorado fault appears to be truncated by the dextral La Cruz fault.

\subsection{Hihitiij Fault}

The Hihitiij fault is a significant, previously unmapped normal fault in the La Cruz domain (Fig. 3). It strikes N-S and dips steeply $\left(\sim 70^{\circ}\right)$ to the west. Along the Hihitiij fault, early to middle Miocene units of volcaniclastic sediments (Tvs), the tuff of Ensenada de La Cruz (Tlc), and the rhyolite flows of Punta Amarillo (Trpa2,3) in the hanging wall are juxtaposed against metasedimentary rocks (Pzms) and Miocene volcaniclastic sediments $(T v s)$ in the footwall. We estimate that the Hihitiij fault 
accommodated at least $1 \mathrm{~km}$ of dip-slip displacement based on offset of the MioceneCretaceous nonconformity, which occurs $\sim 1 \mathrm{~km}$ east of its trace in the footwall and $\sim 3$ $\mathrm{km}$ west of its trace in the hanging wall. Total fault slip likely diminishes northward, where the Hihitiij fault juxtaposes the same rock unit (Tvs), possibly due to slip transfer to a crosscutting, NW-striking dextral strike-slip fault with $\sim 120 \mathrm{~m}$ of apparent dextral displacement (Fig. 3). Farther along strike to the north, the Hihitiij fault may either end at a fault tip or bend to the northwest where it may accommodate dextral strike-slip motion. The timing of activity on the Hihitiij fault is poorly known, but must post-date middle Miocene time and pre-date the crosscutting strike-slip fault.

\subsection{Additional Normal Faults and Related Folds}

Additional normal faults with relatively less displacement deform rocks throughout southern Isla Tiburón (Fig. 3), but are most abundant in the La Cruz domain, between the La Cruz fault and the offshore Tiburón transform fault. Here, N- to NNWstriking normal faults structurally duplicate tilted blocks of early to middle Miocene volcanic and sedimentary units (e.g. Tb, Tvs, Tlc, Trpa) and underlying basement and plutonic units (e.g. Pzms, Kt) (Fig. 10A). These faults are typically inclined moderately to steeply down to the west, although a few east-dipping, antithetic(?) faults are also observed. This style of faulting is common near Ensenada de las Cruces (Fig. 3), where dip-slip displacement ranges up to $500 \mathrm{~m}$ (e.g. Fig. 10D). Late Miocene non-marine conglomerate deposits of the La Cruz basin (Tcg2) bury these normal faults.

Another common style of normal faulting within the La Cruz domain is NE-SWstriking normal faults. Excluding secondary structures in the hanging wall of the Colorado fault, this is the predominant style of faulting west of Arroyo Sauzal, where 
these faults juxtapose early middle Miocene volcanic units (e.g. $T b$ ) against plutonic rocks $(K t)$. Younger, La Cruz basin deposits (e.g. Tcg2) are not preserved along these faults, and thus the timing of activity on these faults is poorly known, but must post-date early middle Miocene time. NE-SW-striking, NW-dipping normal faults are less common southeast of Arroyo Sauzal, but where such faults are observed, these deform and offset deposits of late Miocene non-marine conglomerate (Tcg2) within the La Cruz basin (Fig. 3).

Normal faults are less common in the Sauzal domain, northeast of the La Cruz fault (Fig. 3). Where observed, these faults are typically NE- to ENE-striking and inclined moderately to steeply down to the northwest. SE-dipping normal faults are even less common in the Sauzal domain. A N-striking, west-dipping normal fault occurs just east of Sauzal Spring. Displacement across the majority of normal faults mapped northeast of the La Cruz fault (except the Sauzal fault) is minimal (a few tens of meters).

Rocks on southern Isla Tiburón are also deformed by extension-related folds. In the La Cruz domain, a gentle syncline with an interlimb angle of $\sim 130^{\circ}$ occurs in the hanging wall of the Hihitiij fault, immediately west of and parallel to the fault trace (Fig. 3). This syncline deforms middle Miocene volcanic and sedimentary units (e.g. Tvs, Tlc, Trpa). The axial trace is cut by a NW-striking dextral-oblique normal fault and offset by $\sim 120 \mathrm{~m}$ of dextral separation. Additional folds are observed in the Sauzal domain, just south of Sauzal Spring. Here, a gentle to open syncline and anticline occur in the hanging wall and footwall, respectively, of a west-dipping normal fault (Fig. 10E). This fault and related folds deform latest(?) middle Miocene units (e.g. Tcgl, Ttsf) and displays a few tens of meters of total displacement. 


\subsection{Thrust Faults and Related Folds}

Thrust faults on southern Isla Tiburón deform rocks adjacent to the La Cruz fault (Fig. 3). Northeast of the fault, a pair of E-W-striking, oppositely dipping thrust faults bound the only known plutonic exposure in the Sauzal domain (Figs. 3 and 10D). Another thrust fault occurs southwest of the La Cruz fault, between the Arroyo Sauzal delta and Saguaro Pass, adjacent to a subtle left (restraining) fault bend (Fig. 3). This thrust fault strikes NW-SE and dips gently $\left(30^{\circ}\right)$ to the northeast, juxtaposing latest middle Miocene rhyolite flows of Punta Amarillo (Trpa2) structurally above younger, late Miocene non-marine conglomerate $(T c g 2)$ of the La Cruz basin. Additional thrust faults and folds are present on both sides of the La Cruz fault on southwest Isla Tiburón (Bennett et al., 2015).

Compression-related folds also deform rocks on southern Isla Tiburón. South, west, and northwest of Hast Hinamj, axial traces of gentle folds $\left(\sim 140-160^{\circ}\right.$ interlimb angles) are oriented approximately NE-SW and E-W (Figs. 3 and 10A). Near the shoreline, a set of folds deform plutonic rocks and the entire early to middle Miocene stratigraphic section: early Miocene basalt $(T b)$, non-marine conglomerate $(T c g 1)$, and the 12.2 Ma tuff of San Felipe (Ttsf). On the southwest flank of Hast Hinamj, one fold has been cut by a younger, east-dipping normal fault. It is unclear if this fold deforms the undulatory, sub-horizontal basal contact of the dacite of Hast Hinamj (Tdhh). Hast Hinamj marks a structural transition in the La Cruz domain: to the northwest stratigraphic units typically are inclined down to the north and northwest, whereas to the southeast units typically are inclined down to the northeast (Figs. 3 and 10A). Folds also occur northeast of the La Cruz fault in the Sauzal domain, where red volcaniclastic sandstone 
and lacustrine limestone strata $(T s r)$ are folded across $\sim$ E-W-striking axial planes (Figs. 3 and 10D). Additional folds deform latest(?) middle Miocene non-marine conglomerate (Tcg1) and the $\sim 12.2$ Ma tuff of San Felipe (Ttsf) within a zone of left-stepping (restraining) splays of the dextral La Cruz fault just west of the Arroyo Sauzal drainage (Fig. 3). These folds trend NE-SW and are compatible with predicted secondary structures in a dextral transtensional wrench zone (Sanderson and Marchini, 1984).

\section{HISTORY OF FAULTING AND BASIN FORMATION ON SOUTHERN ISLA TIBURÓN}

The structural and stratigraphic architecture of southern Isla Tiburón records the history of rift-related faulting and syn-tectonic basin formation. We use our observations of these relationships and numerous geochronologic age constraints (Fig. 8; Table 4) to interpret (1) the timing of two deformation phases and related basin sedimentation, and (2) the magnitude of dextral faulting on the La Cruz fault zone.

\subsection{Timing of Faulting and Basin Formation}

\subsubsection{Phase 1: Middle to Late(?) Miocene Normal Faulting and Basin Formation}

On southern Isla Tiburón, evidence for the earliest faulting comes from several normal faults that cut early to middle Miocene volcanic rocks. This early normal faulting phase (Phase 1) includes the Sauzal and Colorado normal faults. Thick (>200 m) sections of latest(?) middle Miocene deposits, consisting of non-marine conglomerate (Tcgl) and the $\sim 12.2$ Ma tuff of San Felipe (Ttsf), are observed adjacent to these normal faults. Contrasting magnitudes of hanging wall and footwall block tilting and the distribution and age of these latest(?) middle Miocene deposits provides constraints on the magnitude, style, and timing of fault activity. 
The magnitude and style of fault offset on and the age of hanging wall units associated with the Colorado and Sauzal faults are similar. Both faults display a similar magnitude $(\sim 1.5-1.7 \mathrm{~km})$ of total dip-slip displacement. Their hanging wall blocks were both tilted by greater amounts than their footwall blocks, forming an angular unconformity only within their hanging wall blocks. In the hanging wall of the Colorado fault, latest(?) middle Miocene conglomerate and the tuff of San Felipe overlie early Miocene basalt flows above an angular unconformity (Figs. 9A and 10A), suggesting hanging wall block tilting began prior to $\sim 12.2$ Ma. In the hanging wall of the Sauzal fault, middle Miocene sediments and the tuff of San Felipe overlie poorly stratified volcanic breccia and lava flows, where the presence of a similar angular unconformity is likely, but difficult to verify (Fig. 10E).

The footwall blocks of the Colorado and Sauzal faults also share similar histories, which are slightly different than their hanging wall block histories. In the footwall of the Colorado fault southeast of the Arroyo Sauzal delta, the contact between early to middle Miocene volcanic rocks and latest(?) middle Miocene strata appears to be conformable. Though the $\sim 12.2$ tuff of San Felipe is absent here, the $\sim 12.2$ Ma tuff of Ensenada de La Cruz and the overlying rhyolite flows of Punta Amarillo are present and are tilted approximately the same amount as the underlying early to middle Miocene rocks (e.g. $T b$, Tvs; Figs. 10C and 10D). Conglomerate deposits (Tcgl) that overlie these volcanic units are gradually less inclined up-section (fanning dips), with the uppermost Tcgl beds inclined similar to the basal contact of the overlying $~ 7.9$ Ma basalt breccia of Alta Sauzal (Tbas; Fig. 10C). This suggests that normal-fault related tilting began after $\sim 12.2$ Ma in the footwall of the Colorado fault. In the footwall of the Sauzal fault, exposures of 
these Tcgl sediments and the $\sim 12.2$ Ma tuff of Ensenada de La Cruz are very limited. Where exposed $\sim 3 \mathrm{~km}$ southeast of Sauzal Spring, these units overlie early Miocene volcanic rocks above an erosional unconformity, but are tilted by a similar amount as the underlying units (Fig. 10E).

Together, these relationships support the interpretation that the Colorado and Sauzal faults were half-graben listric(?) normal fault systems and their tectonic escarpments controlled the spatial extent of relatively thick latest(?) middle Miocene conglomerate deposition and ash-flow tuff emplacement (Figs. 10A and 10E). These deposits overlie the hanging wall angular unconformity are mostly restricted to, and are relatively thicker within, the half-graben hanging wall region immediately west of the Colorado and Sauzal faults (Fig. 3). Although the hanging wall blocks of these normal faults appear to have begun tilting prior to $\sim 12.2 \mathrm{Ma}$, their footwall blocks appear to have begun tilting after $\sim 12.2 \mathrm{Ma}$, recorded by an erosional, rather than angular, unconformity. This is sparse evidence of an angular unconformity in these footwall blocks. However, where observed, the angular discordance is subtle and smaller than the discordance observed in the hanging wall blocks. We interpret these relationships as evidence that Tcgl conglomerate and the tuff of San Felipe were syn-tectonic units that accumulated in the hanging walls during normal fault activity on the Colorado and Sauzal faults.

The onset of normal faulting on the Sauzal fault and Colorado fault is poorly constrained, but post-dates $\sim 19-17 \mathrm{Ma}$, the age of the youngest units (e.g. $T b, T b a$ ) that are cut by these normal faults and underlie the hanging wall angular unconformity. Syntectonic deposits of coarse non-marine conglomerate and interbedded tuffs overlie the hanging wall angular unconformity (Figs. 10A and 10E), which suggests that normal 
faulting and hanging wall block tilting initiated prior to $\sim 12.2 \mathrm{Ma}$, similar to middle Miocene normal faulting documented in western Sinaloa (Ferrari et al., 2013).

A minimum age for this early phase of normal faulting is difficult to assign as normal faulting continued after 12.2 Ma and likely into the subsequent phase of strikeslip faulting. Fault kinematic data broadly support these timing constraints, as faults measured in pre-8 Ma rocks are dominated by $\mathrm{N}$ - to NE-striking normal faults with moderate to steep slip vectors (Fig. 3). Importantly, several Phase 1 normal faults on southeastern Isla Tiburón are buried and capped by latest Miocene to earliest Pliocene deposits of the La Cruz basin and cut by NW-striking strike-slip faults (Figs 3 and 10). These crosscutting relationships signify an important transition from predominantly normal fault activity to a more transtensional regime.

\subsubsection{Phase 2: Late Miocene to Pliocene(?) Strike-Slip Faulting and Basin Formation}

We document structural crosscutting relationships and syn-tectonic basin development that constrain the onset of activity on the La Cruz strike-slip fault. NWstriking dextral and NNE-striking sinistral strike-slip faults cut and deform older normal faults (e.g. Sauzal and Colorado faults) and latest(?) middle Miocene sedimentary and volcanic deposits (e.g. Tcgl, Ttsf) that accumulated in the hanging wall of these faults. This relationship suggests that strike-slip faulting (Phase 2) commenced after the onset of earlier, Phase 1 normal faulting.

Timing information for the onset of strike-slip activity on the La Cruz fault is constrained by syn-tectonic deposits of the La Cruz basin, which accumulated in an elongate trough, or negative flower structure, that formed along the fault zone. Approximately $3 \mathrm{~km}$ east of the Arroyo Sauzal delta, La Cruz basin conglomerate (Tcg2) 
overlies the $\sim 7.9$ Ma basalt breccia of Alta Sauzal (Tbas) above a $\sim 5-15^{\circ}$ angular unconformity (Fig. 10C). Along strike to the northwest, we document a $\sim 6.9 \mathrm{Ma}$ ash bed interstratified near the base of a highly deformed section of $T c g 2$ within the La Cruz fault zone (Fig. 10B). Together, these observations and bracketing volcanic ages suggest that strike-slip deformation, as recorded by the onset of syn-tectonic conglomerate deposition in the La Cruz basin, initiated $~ 8-7$ Ma. Along the northwesternmost onshore exposure of the La Cruz fault, marine strata in the SWIT basin accumulated above an angular unconformity that cuts across early Miocene volcanic rocks and was related to dextral motion on the fault. Here, Bennett et al. (2015) documented a $\sim 6.4 \mathrm{Ma}$ ash-flow tuff at the base of this basin, below the marine strata, which supports a similar history of latest Miocene activity on the La Cruz fault.

Slip on the La Cruz fault appears to have ceased largely by 4.4-3.5 Ma. At Hipat Mesa, relatively undeformed deposits of non-marine conglomerate (Tcg3) and the 4.4 Ma tuffs of Hipat Mesa (Tthm) bury and cap deformed, syn-tectonic La Cruz basin fill (Figs. 3 and 4), similar to a $\sim 3.5-4.1$ Ma capping lava flow near the southwestern tip of the island (Bennett et al., 2015). Fault kinematic data broadly support these timing constraints for strike-slip faulting, as faults measured in 8-4 Ma rocks are dominated by steep, NW-striking faults with moderate to shallow slip vectors (Fig. 3 stereonet insets).

\subsection{Magnitude of Dextral Faulting on the La Cruz Fault}

\subsubsection{Dextral Offset of Early to Middle Miocene Units}

Prior to this study, total dextral displacement along the La Cruz fault was not well constrained (Oskin and Stock, 2003b). The results of our detailed mapping (Fig. 3) reveal correlative deposits of early to middle Miocene volcanic rocks and two latest middle 
Miocene ash-flow tuffs across the La Cruz fault. We use a simplified geologic and structural map (Fig. 11A) of the present-day distributions of these units to draw connections between the La Cruz and Sauzal structural domains southwest and northeast of the fault, respectively, and to estimate total dextral displacement (Fig. 11B). These units may also prove useful in future investigations of offset on the Tiburón transform fault, between Isla Tiburón and Isla Ángel de al Guarda.

The oldest correlative units we document across the La Cruz fault are two widespread sub-sequences that are part of the early to middle Miocene volcanic and sedimentary sequence (Fig. 11A). The first sub-sequence (gray units on Fig. 11) consists of basalt flows and discontinuous beds of reddish volcaniclastic sandstone and lacustrine limestone. Over much of the La Cruz domain, these units lie near the base of the early Miocene section (Fig. 3). The second sub-sequence (blue units on Fig. 11) consists of andesitic flows and breccias, which are consistently found to stratigraphically overlie the basaltic sub-sequence. The basaltic sub-sequence (gray units on Fig. 11) occurs across the western and central portions of the La Cruz domain, where it is relatively thick and widespread. It also occurs within the eastern portion of the Sauzal domain, where it is relatively thin (Figs. 3 and 10), and overlies older andesitic rocks that are not exposed in the La Cruz domain (not colored on Fig. 11; see Fig. 3). The overlying andesitic subsequence (blue units on Fig. 11) primarily occurs within the Sauzal domain, but importantly, it also occurs within the La Cruz domain adjacent to the La Cruz fault (Figs. $3,10 \mathrm{~B}$, and 11). We document how exposures of the basaltic sub-sequence thin from west to east (Fig. 3) and speculate that this thinning pattern continues across the La Cruz fault, which would explain the relatively thin basaltic sub-sequence exposed within the 
Sauzal domain (Fig. 10C). In contrast, the andesitic sub-sequence appears thickest to the northeast (Figs. 10C, 10D, and 10E) and is relatively thinner to the southwest (Figs. 3 and 10B).

Direct correlation across the La Cruz fault of individual flows or map units from these basaltic and andesitic sub-sequences is complicated by an unknown amount of down-to-the-northeast displacement together with moderate amounts of block tilting down towards the fault zone. Such vertical motion contributes to juxtaposition of disparate stratigraphic levels and thicknesses of these sub-sequences. These factors preclude a robust and unique estimate of dextral offset across the La Cruz fault using these sub-sequences. However, restorations of $\sim 5-15 \mathrm{~km}$ of dextral motion bring these similar units into general juxtaposition (e.g. Fig. 11). Thus, the total post-early Miocene dextral offset on the La Cruz fault is likely less than the minimum of $28 \mathrm{~km}$ predicted by Oskin and Stock (2003b).

\subsubsection{Dextral Offset of Latest(?) Middle Miocene Units}

Correlation of latest(?) middle Miocene units on either side of the La Cruz fault provides a more robust estimate of dextral offset on the fault (Fig. 11). Northeast of the fault in Arroyo Sauzal, we map a sequence of latest(?) middle Miocene volcanic and sedimentary units that consists of non-marine conglomerate (Tcgl) with interbeds of the 12.2 Ma tuff of San Felipe (Ttsf) and discontinuous, thin ash beds. This sequence is exposed in an $~ 4.5$-km-long, ENE-striking, south-dipping belt that is gradually deflected in a clockwise sense to a more ESE-striking orientation proximal to the dextral La Cruz fault (Figs. 3 and 10E). Southwest of the fault, we map a similar yet discontinuously exposed sequence in a $\sim 4-\mathrm{km}$-wide, gently NE-dipping belt (Figs. 3 and 10A). We 
interpret these 4-5-km-wide belts of Ttsf to be correlative exposures of an elongate, NESW trending, fault-controlled paleovalley that accumulated deposits of non-marine conglomerate and the tuff of San Felipe (Fig. 11B). Direct evidence for a NE-SWtrending paleovalley margin is observed only in one location northeast of the La Cruz fault (near Sauzal Spring), where 60-m-thick Ttsf deposits abruptly pinch out to the east over a distance of $\sim 150 \mathrm{~m}$ (Fig. 3). Elsewhere, the margins of this paleovalley are inferred but not exposed due to subsequent erosion or burial by younger units (e.g. $T c g 2$, Tthm). Nonetheless, by using the mapped extent of the Ttsf belts on each side of the La Cruz fault as minimum widths of this NE-SW-trending paleovalley (Fig. 11A), we restore these outcrop belts (Fig. 11B). From this, we estimate $5 \pm 2 \mathrm{~km}$ of dextral displacement across the La Cruz fault (Fig. 11B).

Restoration of $5 \pm 2 \mathrm{~km}$ of dextral motion along the La Cruz fault also brings the Colorado fault and Sauzal fault into close alignment (Fig. 11B), suggesting that these faults, which share similar dip-slip magnitudes and timing histories, may have been a single, correlative structure that was subsequently cut and offset by dextral slip on the La Cruz fault. This fault correlation remains uncertain as it is complicated by subsequent dip-slip motion on the La Cruz fault that exposes different structural levels. Dextral shear across the La Cruz fault likely produced nearby clockwise vertical-axis block rotation (e.g. Bennett and Oskin, 2014) and may have rotated the orientation of the Colorado and Sauzal normal faults in a clockwise sense. The fault-controlled paleovalley of Ttsf likely connected to a more widespread and continuous sheet of Ttsf deposits documented by Oskin et al. (2001) and Oskin and Stock (2003b) in the Sierra Menor and beneath Valle de Tecomate to the northwest and north, respectively (Fig. 2). This paleovalley on 
southern Isla Tiburón likely continued to the southwest, toward the Tiburón transform fault. We speculate that Ttsf exposures documented on central Isla Ángel de la Guarda (Fig. 1; Stock et al., 2008; Skinner et al., 2012), may correlate to the Ttsf exposures on southern Isla Tiburón, providing a potential tie-point that constrains $\sim 90-120 \mathrm{~km}$ of dextral displacement across the Tiburón transform fault since $~ 12.2$ Ma.

We also correlate exposures of the $\sim 12.2$ Ma tuff of Ensenada de la Cruz (Tlc) across the La Cruz fault (Fig. 3). Southwest of the fault, outcrops of Tlc vary along strike from $~ 50$-m-thick, densely-welded deposits in the southeast (Fig. 10D) to thin $(<12 \mathrm{~m})$ and discontinuous, slightly- to non-welded deposits in the northwest (Fig. 10C). Northeast of the La Cruz fault, Tlc deposits are very discontinuous and only observed to be $\sim 5-12 \mathrm{~m}$ thick in isolated paleovalley(?) exposures (e.g. Fig. 10E). Thus, $T l c$ is a poor marker for directly estimating total dextral displacement across the La Cruz fault. However, its limited original distribution and modern-day proximity on either side of the La Cruz fault suggest a relatively small magnitude of post- 12 Ma dextral displacement and lends support to our estimate of only $5 \pm 2 \mathrm{~km}$ of dextral displacement of the Ttsf paleovalley (Fig. 11).

\subsubsection{Dextral Offset of Late Miocene Units}

Younger, late Miocene (post-8 Ma) units also correlate across the dextral La Cruz fault, including the La Cruz basin deposits (Tcg2). Tcg2 deposits are faulted and folded and its basal contact is cut and offset by the multiple strands of the La Cruz fault zone (Fig. 3). Highly deformed marine strata of similar age (6.4-6.0 Ma) in the southwest Isla Tiburón basin are dextrally offset no more than $1 \mathrm{~km}$ along the La Cruz fault (Fig. 3; 
Bennett et al., 2015). Thus, the majority of the $5 \pm 2 \mathrm{~km}$ of dextral displacement along the

La Cruz fault must have occurred between $\sim 8 \mathrm{Ma}$ and $\sim 6 \mathrm{Ma}$.

\section{REGIONAL IMPLICATIONS}

\subsection{Regionally Synchronous Onset of Transform Faulting in the Gulf of California}

Dextral slip on the La Cruz fault initiated during late Miocene time ( 8-7 Ma, reported above). This timing is compatible and synchronous with the onset of transform faulting and more focused and oblique transtensional deformation along a significant length of the Pacific-North America plate boundary in northwest Mexico and southern California (Fig. 12). Direct evidence for focused transtension in the form of mapped strike-slip faults, clockwise vertical-axis block rotation, and/or fault exhumation is restricted to onshore exposures adjacent to the northern Gulf of California. Indirect evidence comes from onshore and offshore pull-apart basins kinematically linked to significant dextral strike-slip faults.

\subsubsection{Evidence From the Sonora Rift Margin}

On the eastern, Sonora rift margin, the majority of strike-slip faulting, clockwise block rotation, block tilting, and transtensional basin subsidence initiated ca. 8-7 Ma in the Coastal Sonora fault zone (Fig. 12; Bennett et al., 2013; Bennett, 2013; Darin et al., this volume). These findings are consistent with latest Miocene to Pliocene (7-4 Ma) apatite fission track ages documented throughout coastal Sonora, which are interpreted as a minimum age for the onset of exhumation related to transtensional shearing (LugoZazueta et al., 2010). Farther to the southeast, along structural strike, Herman (2013) documented a zone of significant late Miocene dextral deformation and clockwise vertical-axis block rotation in the Sierra El Aguaje, west of Guaymas (Fig. 12), that may 
be related to either the Coastal Sonora fault zone or proximity to the southeastern continuation of the La Cruz fault and Tiburón transform.

\subsubsection{Evidence From the Baja California Rift Margin}

On the western, Baja California rift margin, direct geologic evidence suggests that the majority of transtensional deformation also commenced in latest Miocene time ca. 8$7 \mathrm{Ma}$ (Fig. 12). In the Salton Trough, subsidence in the hanging wall of the West Salton Detachment fault, which was linked to dextral motion on the southern San Andreas Fault system, began at $8.0 \pm 0.4 \mathrm{Ma}$ (Dorsey et al., 2007; 2011). In northeastern Baja California, on the conjugate rift margin to Isla Tiburón and coastal Sonora, Lewis and Stock (1998a,b) and Seiler et al. (2010) documented a series of syn-tectonic basins (e.g. Santa Rosa basin) related to regional dextral shear, which was accommodated via clockwise vertical-axis block rotation, sinistral slip on NE-striking strike-slip faults, and east- to southeast-directed extension above detachment faults. Basins that formed adjacent to and above these faults contain growth strata with basal depositional ages of 76 Ma (Boehm, 1984; Seiler et al., 2010). Low-temperature thermochronologic analysis of normal faults that controlled basin formation indicates that exhumation related to oblique rifting in northeastern Baja California initiated between 9-7 Ma (Fig. 12; Seiler et al., 2011). Farther south, the onset of crustal extension and fault exhumation related to dextral-oblique normal faulting and formation of the Loreto basin is similarly bracketed between $\sim 8-6 \mathrm{Ma}$ (Fig. 12 inset; Mark et al., 2014). This timing is similar to the $\sim 9-8 \mathrm{Ma}$

onset of fault exhumation documented on the western rift margin in southeastern Baja California (Fig. 12 inset; Kohn et al., 2010).

\subsubsection{Evidence From Concealed Pull-apart Basins}


Indirect evidence for the onset of transform faulting comes from geological and geophysical examination of concealed pull-apart basins kinematically linked to significant dextral strike-slip faults along a >1,000 km-long length of the Gulf of California (Fig. 12). In the Altar desert of northwesternmost Sonora (Fig. 12), Pacheco et al. (2006) document the onset of syn-tectonic sediment accumulation in the Altar pullapart basin ca. 7-6 Ma. This basin formed above the hanging wall of the Altar detachment fault, coeval with top-to-the-northwest extension that was kinematically linked to dextral strike-slip motion on the NW-striking Altar fault, a southeastward continuation of the southern San Andreas Fault system.

Approximately $350 \mathrm{~km}$ to the southeast of Isla Tiburón, offshore Sinaloa and along strike with the Ballenas transform fault, Miller and Lizarralde (2013) document $~ 7$ Ma deposits of marine evaporite that floor the east Guaymas transtensional marine basin that formed during oblique opening of the Guaymas rift segment (Fig. 12 inset). In the southernmost Gulf of California, across the Alarcon rift segment (Fig. 12 inset), Sutherland et al. (2012) document a phase of oblique extension ca. 8-5 Ma, supported by the presence of syn-rift deposits that overlie volcanic rocks as young as 11-9 Ma and are located adjacent to related strike-slip faults. Sutherland et al. (2012) also suggest an earlier phase of transtension ca. 14-11 Ma, though direct evidence for its association with dextral strike-slip faulting is lacking from their geophysical data. Alternatively, formation of these middle Miocene basins could be due to east-west extension documented in adjacent western Sinaloa (e.g. Ferrari et al., 2013), and similar to that accommodated by the Sauzal and Colorado normal faults on Isla Tiburón. 
In summary, there is widespread evidence of a tectonic reorganization in the Gulf of California rift in the late Miocene between 8 and 6 Ma that led to a more intensive, localized, and oblique rift, characterized by significant block tilting, clockwise block rotation, and tectonic subsidence (Fig. 12). This transition led to the development of the Gulf of California shear zone, a 50-100 km-wide transtensional belt of long transform faults, linked pull-apart basins, and clockwise vertical-axis block rotations (Bennett and Oskin, 2014). The Gulf of California shear zone accrued several tens of km of dextral displacement in a few million years (e.g. Bennett et al., 2013; Vidal-Solano et al., 2013), a strain rate comparable to that of the plate boundary that eventually developed here. If earlier proto-Gulf deformation was transtensional in character (c.f. Gans, 1997; Fletcher et al., 2007), it was probably more diffuse and akin to the Basin and Range extension that preceded it than the nascent plate-boundary dextral shear zone that followed.

\subsection{Consequences of Increased Obliquity of PAC-NAM Relative Plate Motion}

Although a global plate circuit model indicates that rapid $(\sim 5 \mathrm{~cm} / \mathrm{yr})$ PAC-NAM dextral-oblique motion was underway by $\sim 12.3 \mathrm{Ma}$ at the latitude of Baja California (Atwater and Stock, 1998), development of significant, embedded dextral transform faults within the rift (Gulf of California shear zone) was delayed by 4-5 Myr. This delay suggests that the degree of plate motion obliquity during earliest oblique rifting was insufficient to promote the development of transform faults and localize the dextral shear component of PAC-NAM relative motion.

Based on the regional synchronicity of concentrated oblique deformation, now preserved within the margins of the northern Gulf of California, it appears that rift localization was facilitated by the development of long transform faults during latest 
Miocene time (ca. 8-6 Ma), 1-2 Myr prior to rift localization at ca. $6 \mathrm{Ma}$. This timing is conspicuously similar to the onset of a significant azimuthal change in PAC-NAM relative plate motion predicted by the global plate circuit model (Atwater and Stock, 1998; Atwater and Stock, 2013). During chron 4 (a magneto-chron time interval from 8.8-7.5 Ma; see Lourens et al., 2004), the PAC-NAM relative plate motion vector began to rotate clockwise at the latitude of the Gulf of California. At the latitude of Isla Tiburón, the PAC-NAM relative plate motion direction was $\sim 300^{\circ}$ from $\sim 11-8 \mathrm{Ma}$ (Atwater and Stock, 2013). Between $\sim 8 \mathrm{Ma}$ and $\sim 6 \mathrm{Ma}$, relative plate motion rotated $\sim 12^{\circ}$ to an azimuth of $\sim 312^{\circ}$. By $\sim 3 \mathrm{Ma}$, relative plate motion had rotated a total of $\sim 17^{\circ}$ since $\sim 8$ $\mathrm{Ma}$, and was oriented at azimuth $\sim 317^{\circ}$. This progressive rotation of relative plate motion increased the obliquity of rifting by reducing the angle between the relative plate motion and the regional trend of the plate boundary, drawn from the Salton Sea to the Rivera triple junction at the mouth of the Gulf of California.

We speculate that the azimuth of the La Cruz fault $\left(302^{\circ}\right)$ preserves an earlier (ca. $8 \mathrm{Ma}$ ) signature of relative plate motion, which was oriented $\sim 300-312^{\circ}$ azimuth. Significant dextral motion on strike-slip faults in the Coastal Sonora fault zone, near Bahía Kino and across northeastern Isla Tiburón, initiated $\sim 8$-7 Ma and are oriented similar $\left(\sim 302-308^{\circ}\right)$ to the La Cruz fault (Bennett et al., 2013; Bennett, 2013). In contrast, transform faults at the latitude of Isla Tiburón that developed later (post-6 Ma) and serve as the primary plate boundary today (e.g. Ballenas transform) are oriented $\sim 315^{\circ}$, more northerly (clockwise) than the orientation of the La Cruz fault and Coastal Sonora fault zone (Fig. 1). Thus, it appears that subtle differences in the orientation of transform and strike-slip faults reflects the evolving orientation of PAC-NAM relative 
plate motion, where the orientation of structures may mimic the relative plate motion direction during fault development and activity.

Analog clay and sand-silicone models of oblique rifts illustrate the diverse structural styles that develop from variable angles of rift obliquity (Withjack and Jamison, 1986; Bonini et al., 1997; Clifton et al., 2000; Clifton and Schlische, 2001; Corti et al., 2001). Importantly, only highly oblique rifts, with $\leq 30^{\circ}$ between relative plate motion and the plate boundary, develop significant strike-slip faults in these models (Clifton et al., 2000). For a reference point that tracks PAC-NAM relative motion at the latitude of Isla Tiburón, the clockwise shift that occurred ca. 8-6 Ma altered the angle of rift obliquity from $\sim 30^{\circ}$ to $\sim 18^{\circ}$. Thus, the Gulf of California appears to have crossed a critical plate-kinematic threshold during latest Miocene time, when an increase in rift obliquity spurred the synchronous development of major dextral transform faults along much of the rift, resulting in a focused zone of oblique divergence (the Gulf of California shear zone; Fig. 12) along which rifting eventually proceeded to plate boundary localization ca. 6 Ma.

If the Gulf of California shear zone was only active for $~ 2$ Myr before the plate boundary localized west of Isla Tiburón (Oskin et al., 2001), then no more than $\sim 100 \mathrm{~km}$ of PAC-NAM dextral shear could have accrued in this zone east of Isla Tiburón during proto-Gulf time. This is consistent with our estimates of total dextral shear across Isla Tiburón and with estimates in coastal Sonora (Bennett et al., 2013; Vidal-Solano et al., 2013) and northeastern Baja California (Lewis and Stock, 1998a), but conflicts with tectonic models that invoke much larger magnitudes $(150-250 \mathrm{~km})$ of proto-Gulf dextral deformation here (e.g. Nicholson et al, 1994; Gans, 1997; Wilson et al, 2005; Fletcher et 
al., 2007; Seiler et al., 2010). Older, distributed transtension across the western Mexican Basin and Range (Fig. 1 inset) likely contributed additional dextral slip to the full plateboundary budget (e.g. Gans, 1997), but no significant pre-9 Ma strike-slip faults have been documented that compare with the proto-Gulf transform faults in westernmost Sonora and on Isla Tiburón.

Following the late Miocene development of the Gulf of California shear zone, the Gulf of California progressed to a localized rift, became host to a marine seaway, and proceeded quickly to continental rupture. Intense oblique-divergent motion throughout latest Miocene time caused lithospheric thinning and subsidence that formed incipient pull-apart basins at or below sea level. Sufficient crustal thinning and subsidence within the Gulf of California shear zone allowed the regionally synchronous marine flooding of the northern Gulf of California ca. 6.5-6.3 Ma (Oskin and Stock, 2003a; Bennett et al., 2015). Rift localization occurred within the core of this Gulf of California shear zone, but was delayed until $\sim 6 \mathrm{Ma}$ (Oskin et al., 2001; Oskin and Stock, 2003b), at least 1-2 Myr after the onset of transform faulting. Eventually, within the northern Gulf of California, extreme crustal thinning across pull-apart basin detachment faults (Gastil and Fenby, 1991; González-Fernández et al., 2005) facilitated Pliocene-Pleistocene continental rupture along its western edge (Martín-Barajas et al., 2013).

\subsection{A Modern Analog: the Walker Lane}

The late Miocene Gulf of California shear zone probably bore similarities to the modern-day Walker Lane belt of the western Basin and Range Province of California and Nevada (Faulds et al., 2005; Henry and Faulds, 2006). In both areas, the shear zone developed along the axis of a former, subduction-related volcanic arc (Hausback, 1984; 
Umhoefer et al., 2001; Busby et al., 2012). This zone of thermally weakened and gravitationally unstable lithosphere was oriented slightly oblique (more northerly) to the azimuth of Pacific-North America relative plate motion. The en-echelon patterns of oblique deformation that developed resemble model predictions of oblique extension across pre-existing weak zones (van Wijk, 2005; Brune et al., 2012).

\subsection{The Role of Rift Obliquity in Rupturing Continents}

In northwestern Mexico, protracted Oligocene-Miocene continental extension and volcanism migrated westward (Ferrari et al., 2013), culminating with a late Miocene increase in rift obliquity and Miocene-Pliocene lithospheric rupture. This history led to the strongly asymmetric rifted margins that flank the northern Gulf of California today (Aragón-Arreola and Martín-Barajas, 2006). The Baja California margin is relatively narrow ( $<50 \mathrm{~km}$-wide), while the Sonora margin encompasses a $~ 300 \mathrm{~km}$-wide extensional province (Fig. 1 inset; Stock and Hodges, 1989). This asymmetric geometry resembles other, more mature, rifted continental margins (Louden and Chian, 1999) and model predictions of continental break-up (Bassi, 1995; Huismans and Beaumont, 2003). However, in the case of the Gulf of California, rift margin asymmetry was strongly influenced by the evolving rift obliquity.

Continental rupture and formation of new oceanic rift basins requires focused strain (Buck, 1991). Due to its infancy, the Gulf of California preserves a rare onshore record of early continental break-up processes, and serves as an example of how rift obliquity and formation of transform faults helps facilitate continental rupture. Intrinsically, oblique rifts develop en-echelon patterns of transform faults and connected pull-apart basins (Withjack and Jamison, 1986; van Wijk, 2005). Sub-vertical strike-slip 
faults are relatively unaffected by buoyancy and flexural forces (e.g. Forsyth, 1992) that otherwise restrict fault-slip on non-vertical, normal faults; restrictions that can drive rift widening during orthogonal rifting (Buck, 1991). Thus, strike-slip faults tend to be susceptible to fault weakening and shear heating (Leloup et al., 2002), processes that allow shear zones to be longer-lived (Kaus and Podladchikov, 2006) and accumulate larger displacements. Furthermore, normal faults typically experience horizontal-axis rotation and evolve to more shallow dips with continued slip, placing them in nonoptimal orientations for accumulation of large displacement (c.f. Brady et al., 2000). Subvertical strike-slip faults, on the other hand, can tolerate such fault-plane rotation across releasing or restricting bends. Additionally, unlike strike-slip faults, the length of any single normal fault found in a traditional, orthogonal rift setting may be limited in its growth by the thickness of the brittle crust (Jackson and White, 1989).

Highly oblique rift geometries, where the strike-slip faults that bound rift segments (transform faults) are kinematically linked to adjacent pull-apart basins, may favor the formation of large-offset, translithospheric detachment faults (e.g. Tucholke et al., 1998) and are likely more efficient at localizing the strain necessary for continental rupture than orthogonal rifting (Bennett, 2011; Brune et al., 2012). Several structural and geophysical studies throughout the Gulf of California and Salton Trough demonstrate the abundance of large-offset normal faults kinematically linked to zones of transform faults with high transtensional strain rates (e.g. Axen and Fletcher, 1998; González-Fernández et al., 2005; Pacheco et al., 2006; Seiler et al., 2010; Dorsey et al., 2011; Bennett et al., 2013; Martín-Barajas et al., 2013), consistent with the notion that an oblique, en-echelon 
rift architecture enhances the ability to rupture continental lithosphere and form a new oceanic rift basin.

\section{SUMMARY AND CONCLUSIONS}

The Gulf of California preserves a rare, youthful onshore record of oblique continental break-up processes, where transform faults kinematically linked to adjacent pull-apart basins appear to have efficiently localized the strain necessary for continental rupture, consistent with numerical modeling studies of oblique rifting (e.g. Brune et al., 2012). Rift-related structures and syn-tectonic basins on Isla Tiburón, a proximal onshore exposure of the rifted North America margin in the Gulf of California, preserve a twophase record of fault activity and basin formation. Phase 1: On southern Isla Tiburón, an early phase of extension across the Sauzal and Colorado normal faults initiated sometime after $\sim 19-17 \mathrm{Ma}$ and was ongoing by $\sim 12.2 \mathrm{Ma}$, similar to Basin and Range extension documented in western Sonora and Sinaloa during this time (e.g. Ferrari et al., 2013). Phase 2: Strike-slip faulting commenced $\sim 8-7 \mathrm{Ma}$, after the earlier phase of normal faulting had commenced. Phase 1 normal faults and related basin deposits were subsequently buried by younger, syn-tectonic sediments of the non-marine La Cruz basin, likely rotated clockwise by subsequent dextral shear, and crosscut by the northweststriking La Cruz strike-slip fault, which was active until $\sim 4$ Ma. Reconstruction of the distribution of volcanic units permits an estimate of $5 \pm 2 \mathrm{~km}$ for total dextral slip across the La Cruz fault since $\sim 12.2 \mathrm{Ma}$ (Fig. 11). The La Cruz fault was a significant NWstriking strike-slip structure that developed during latest Miocene time and, along with the Tiburón transform, bounded the southwestern margin of the Upper Delfín-Upper Tiburón rift segment (Fig. 1). These structures were subsequently lengthened offshore, to 
the northwest, where they were kinematically linked to large-offset detachment faults and acted as plate boundary transform faults during earliest (latest Miocene-Pliocene) oblique opening and pull-apart basin formation in the northern Gulf of California (Oskin and Stock, 2003b; Martín-Barajas et al., 2013).

Latest Miocene strike-slip faulting and related basin formation on Isla Tiburón is synchronous with tectono-stratigraphic records of oblique rifting and pull-apart basin formation from both conjugate rifted margins in the northern Gulf of California and along a significant length of the Pacific-North America plate boundary in northwest Mexico and southern California (Fig. 12). At several locations along the $>1,000-\mathrm{km}$-long reconstructed plate boundary, evidence for the onset of shear-dominated transtension is concentrated, in both time and space, along the narrow, NNW-trending Gulf of California shear zone, where earliest transform faulting initiated in the latter part of proto-Gulf time, ca. 8-6 Ma (Fig. 12). The timing of the development of the Gulf of California shear zone broadly corresponds with the establishment of the eastern California shear zone (Dokka and Travis, 1990) and the early Walker Lane system (Faulds et al., 2005). These transtensional systems may have been linked as a once-continuous belt of late Miocene dextral transtension related to the PAC-NAM plate boundary. In northwestern México, earlier ( 12-8 Ma) deformation related to oblique PAC-NAM relative plate motion was transtensional in character (c.f. Gans, 1997; Fletcher et al., 2007), but probably characterized by extension-dominated transtension and more diffuse in nature (e.g. Darin et al., this volume).

Collectively, these findings do not support a regional model that invokes orthogonal rifting with little to no strike-slip faulting prior to $\sim 6 \mathrm{Ma}$ for regions east of 
the Baja California microplate (e.g. Stock and Hodges, 1989). These findings also do not support a regional model that appeals to a single phase of significant and integrated transtensional shear that initiated ca. 12.3 Ma (Fletcher et al., 2010). Rather, our results from southern Isla Tiburón, together with published regional observations, support that significant dextral transtension did not become organized until ca. $8 \mathrm{Ma}$, providing support for a progressive localization model (cf. Bennett, 2009; Seiler, 2009; Seiler et al., 2011; Bennett et al., 2013a; Bennett and Oskin, 2014; Darin et al., this volume), which envisions that transtensional plate boundary deformation gradually localized in latest Miocene time in response to changes in the obliquity of relative plate motion.

The timing of the tectono-stratigraphic transition to strike-slip faulting and basin formation corresponds to a clockwise azimuthal shift in Pacific-North America relative motion ca. 8.8-7.5 Ma, which reorganized plate motions (Atwater and Stock, 1998; 2013) and amplified the effects of rift obliquity within the Gulf of California. Consequently, the Gulf of California rift crossed a critical plate-kinematic threshold that prompted the synchronous development of major dextral transform faults, linked pullapart basins, and clockwise vertical-axis block rotations, forming a focused zone of oblique divergence. Shortly following (1-2 Myr) the development of this Gulf of California shear zone, the northern Gulf of California became host to a marine seaway ca. 6.5-6.0 Ma (Oskin and Stock, 2003a; Bennett et al., 2015) co-located with localization of the incipient plate boundary (Oskin et al., 2001; Oskin and Stock, 2003b). Thus, although rapid ( $\sim 5 \mathrm{~cm} / \mathrm{yr})$ PAC-NAM dextral-oblique motion commenced $\sim 12.3 \mathrm{Ma}$ at the latitude of Baja California (Atwater and Stock, 1998), localization of the plate boundary was delayed for several million years. Strain localization and subsequent continental rupture 
in the Gulf of California was likely facilitated by a transition to highly oblique and localized rifting and the development of major transform faults. The record from the proto-Gulf of California illustrates how highly oblique rift geometries enhance the ability of continental lithosphere to rupture and, ultimately, lead to the formation of new oceanic rift basins. 


\section{ACKNOWLEGMENTS}

Funding from the National Science Foundation Tectonics and MARGINS programs, awards \#0739017 and \#0904337, an ExxonMobil Geoscience Grant, a Geological Society of America Graduate Student Research Grant, a Northern California Geological Society Richard Chambers Memorial Scholarship, and a UC Davis Cordell Durrell scholarship made this research possible. Permission to enter Isla Tiburón was granted by the Secretaría de Medio Ambiente y Recursos Naturales-Comisión Nacional de Areas Naturales Protegidas and the native Cumcaác (Seri) tribe. We thank A. MartínBarajas for assistance with permit acquisition. Reviews by M. Bonini, J. Matti, M. Darin, an anonymous reviewer, and Associate Editor D. Czeck as well as discussions with R. Dorsey and A. Forte all helped improve the manuscript. M. Tappa, M. Iglecia, A. Gauer, and E. Stevens all provided great company, safety, and support while conducting fieldwork on Isla Tiburón. T. Donovan, G. Smart, and the Prescott College Kino Bay Center for Cultural and Ecological Studies staff provided incredible logistical support and comfortable accommodations while conducting fieldwork. We thank the Molina VillaLobos family (Ernesto, Francisco, and Esequel) of the of the native Cumcaác (Seri) tribe for their superb boatmanship and safekeeping during our field research. 


\section{FIGURE CAPTIONS}

\section{Figure 1}

Physiographic map of the northern Gulf of California. Structures related to oblique rifting shown from Fenby and Gastil (1991), Oskin (2002), Aragón-Arreola \& Martín-Barajas (2007), Aragón-Arreola et al. (2005), Darin et al. (this volume), Seiler et al. (2010), Pacheco et al. (2006), Mar-Hernández et al. (2012); Bennett et al. (2013), Bennett (2013); this study. Active Pacific-North America plate boundary structures colored in red. Inactive structures related to early oblique rifting colored black. Rhomboid-shaped transtensional pull-apart basins (yellow lines) from Aragón-Arreola and Martín-Barajas (2007) and Lonsdale (1989). Cross-gulf tie points include ' $F$ '-fusulinid-rich clast conglomerate (Gastil et al., 1973), and widespread tuffs shown in red and green (Oskin et al., 2001; Oskin and Stock, 2003b). Vent locations for widespread tuffs shown with stars. (INSET MAP) Simplified regional tectonic map of Western North America showing the diffuse boundary between the Pacific-North American lithospheric plates (after Oskin and Stock, 2003b). Active faults and spreading centers in red. Stable continental blocks in gray. Extensional provinces in tan.

\section{Figure 2}

Simplified geologic map of Isla Tiburón. Schematic stratigraphic column of geology units shown. Geology compiled from Gastil and Krummenacher (1977a); Oskin, (2002); this study. See Figure 3 legend for description of fault symbology. 


\section{Figure 3}

1: 15,000-scale geologic map of southern Isla Tiburón produced during this study. New and previously published geochronologic sample locations and isotopic ages are shown on map and further synthesized in Figure 8 and Table 4. The upper and lower stereonet panels illustrate the orientation of stratigraphy (bedding, volcanic foliation, etc.) and structures (faults, faults with striae) from the Sauzal and La Cruz domains, respectively. All stratigraphic and structural data is also displayed on the large geologic map. Each panel (Sauzal, La Cruz) of stereonet data are subdivided by the relative age of map units. Printed map sheet is 36 " tall, 90 " wide.

\section{Figure 4}

Schematic stratigraphic columns of geologic map units for southern Isla Tiburón. Lithologic unit indicators and colors correspond to units on geologic map (Fig. 3) and geologic cross sections (Fig. 10). Isotopic ages (in million years) for units are shown in parentheses. See text for descriptions of map units and details of isotopic ages.

\section{Figure 5}

$\mathrm{K} / \mathrm{Ca}$ ratios and ${ }^{40} \mathrm{Ar} /{ }^{39} \mathrm{Ar}$ age spectrum plot (top) and inverse-isotope correlation diagram (bottom) for volcanic matrix from samples of (A) unit 'Tha' in the Sauzal domain, and (B) the basalt breccia of Alta Sauzal. Gray shaded letters indicate steps excluded from the isochron age determination. See Table 1 for analytical data.

\section{Figure 6}


${ }^{40} \mathrm{Ar} /{ }^{39} \mathrm{Ar}$ geochronologic ages calculated for volcanic rocks on southwestern Isla Tiburón. $\%{ }^{40} \mathrm{Ar} *, \mathrm{~K} / \mathrm{Ca}$ ratios, and ranked age plot of multiple, single-grain, total fusion ages on potassium-feldspar crystals (left) and inverse-isotope correlation diagram (right) for samples of (A and C) the tuff of San Felipe (Ttsf) and (B, D, and E) the tuff of Ensenada de La Cruz (Tlc). Crystals omitted from mean age calculation are gray hollow circles (left) and gray shaded ellipses and crystal numbers (right). See Table 2 for analytical data.

\section{Figure 7}

${ }^{206} \mathrm{~Pb} /{ }^{238} \mathrm{U}$ Tera-Wasserburg concordia diagram (left) and ranked age plot (right) for multiple zircon crystals from samples of (A) an ash bed interbedded near the base of the La Cruz basin (Tcg2), and (B) the tuffs of Hipat Mesa that cap the La Cruz basin. Zircon crystals omitted from mean age calculation are gray squares with gray, dashed error ellipses. Relatively younger zircons have high uranium concentrations (open gray squares; Table 3) and are omitted from mean age due to possible lead loss. Relatively older zircons are omitted due to potential inheritance. Black arrow indicates mean age on ranked age plot. See Table 3 for analytical data.

\section{Figure 8}

Summary of all isotopic ages for map units across southern Isla Tiburón from this and previous studies. See text for details and geologic map (Fig. 3) for sample locations and context. Units are schematically lumped (gray boxes) into groups discussed in the text. 


\section{Figure 9}

Field photographs of southern Isla Tiburón. (A) Looking northeast at Hast Hinamj. Early to middle Miocene basalt flows $(T b)$ are overlain by the tuff of San Felipe (Ttsf), which is interbedded amongst latest middle Miocene conglomerate (Tcgl) across an angular unconformity (dashed white line). Sequence is capped by a pre-4 Ma dacite volcanic complex (Tdhh). (B) Looking southeast along Caniip Hiyat (Punta Amarillo), a northeastdipping tilt block of $T v s, T l c(\sim 12.2 \mathrm{Ma}), T t y$, and Tba, capped by Trpa lava flows. See text, geologic map (Fig. 3), and cross sections (Fig. 10) for unit details. (C) Looking east at sea cliff of Caniip Hiyat (Punta Amarillo), where banding in the rhyolite flows of Punta Amarillo (Trpa) indicates a southerly flow direction. (D) Looking northeast at shallowly dipping $\left(\sim 5-15^{\circ}\right)$ La Cruz basin conglomerate (Tcg2) in angular unconformable contact (dashed white line) above moderately dipping ( 20-50 $)$ middle Miocene volcaniclastic strata (Tvs). Geologist, circled, for scale. (E) Looking northwest (left) to east (right) from Hast Hinamj, down over the Hipat Mesa volcanic tableland. (F) Looking northeast (left) to south (right) at Hipat Mesa and Hast Hinamj. Ash and pumice deposits (Tthm) become more inclined towards, and onlap onto, the dacite volcanic complex $(T d h h)$ at Hast Hinamj.

\section{Figure 10}

(A-E) Geologic cross-sections for southern Isla Tiburón. Map unit lithologic indicators, colors, and other symbology as in Figures 3 and 4. Dip values from structural measurements used to construct cross-sections shown near ground surface. Apparent dip 
values shown in parentheses. See geologic map (Fig. 3) for cross-section line locations. Printed cross-section sheet is 24 " tall, 72 " wide.

\section{Figure 11}

(A) Present-day distribution of correlative map units across the La Cruz strike-slip fault. Representative bedding orientations illustrate the gently folded, shallow to moderately dipping nature of map units. (B) Preferred restoration of $\sim 5 \mathrm{~km}$ of dextral slip brings correlative map units into general alignment. Simplified oblique-view block diagrams in each panel illustrate how deposits of the $\sim 12.2$ Ma tuff of San Felipe were likely restricted to a fault-controlled paleovalley, which was subsequently offset by the dextral La Cruz fault.

\section{Figure 12}

Paleo-tectonic map of proto-Gulf of California, restored to 7-6 Ma. Main map shows restored positions of documented latest Miocene transtensional faulting and basin formation (white circles). These locales define a NNW-trending Gulf of California shear zone (red region), where earliest transform faulting initiated in latest Miocene time, ca. 8-6 Ma. The Gulf of California shear zone may have kinematically connected northward with the southern San Andreas system and farther north with the eastern California shear zone and Walker Lane. Farther east, earlier normal faulting is schematically shown in the Basin and Range (large black extension arrows). See Discussion section in text for details. Plots tied to each locale summarize published information about the timing and magnitude of tectonic subsidence (green) and tilting (blue). The onset of rapid basin 
subsidence occurred synchronously in latest proto-Gulf time (vertical gray box) along several 100's of km of the Pacific-North America plate boundary. At the Punta Chueca and Santa Rosa basins, thermochronologic data (black bars) by Lugo-Zazueta et al. (2010) and Seiler et al. (2011), respectively, further constrain the onset of rift-related exhumation. Late Miocene position of cities as small black squares: Y-Yuma, SD-San Diego, PP-Puerto Peñasco, SF-San Felipe, P-Puerticitos, G-Guaymas

(INSET MAP) As inset map in Figure 1, showing present-day locations of latest Miocene transtensional faulting discussed in text, including locations from paleo-tectonic map in main figure panel. FCV-Fish Creek-Vallecitos basin, AB-Altar basin, SRB-Santa Rosa basin, CS-Coastal Sonora \& Isla Tiburón basins, SA-Sierra el Aguaje, EG-Eastern Guaymas basin, L-Loreto basin, SB-Southeastern Baja California, AS-Alarcon rift segment 


\section{REFERENCES CITED}

Andersen, T., 2002, Correction of common lead in U-Pb analyses that do not report Pb204: Chemical Geology, v. 192, no. 1-2, p. 59-79.

Aragón-Arreola, M., and Martín-Barajas, A., Rift-to-drift transition in the Gulf of California, in Proceedings Lithospheric Rupture in the Gulf of California-Salton Trough Region - NSF Margins RCL Workshop, Ensenada, Mexico, 2006.

Aragón-Arreola, M., and Martín-Barajas, A., 2007, Westward migration of extension in the northern Gulf of California, Mexico: Geology, v. 35, no. 6, p. 571-574.

Aragón-Arreola, M., Morandi, M., Martín-Barajas, A., Deldago-Argote, L., and González-Fernández, A., 2005, Structure of the rift basins in the central Gulf of California: Kinematic implications for oblique rifting: Tectonophysics, v. 409, p. 1938.

Atwater, T., and Stock, J., Constraints on the history of the Late Cenozoic Pacific-North American plate boundary from marine magnetic anomalies and global plate circuits, in Proceedings Geological Society of America Cordilleran Section - 109th Annual Meeting, Fresno, CA, 2013, Volume 45, p. 21.

Atwater, T., and Stock, J. M., 1998, Pacific North America plate tectonics of the Neogene southwestern United States: An update: International Geology Review, v. 40, no. 5, p. $375-402$.

Axen, G. J., and Fletcher, J. M., 1998, Late Miocene-Pliocene extensional faulting, northern Gulf of California and Salton Trough, California: International Geological Review, v. 40, no. 3, p. 217-244. 
Bassi, G., 1995, Relative importance of strain rate and rheology for the mode of continental extension: Geophys. J. Int., v. 122, p. 195-210.

Bennett, S.E.K., 2009, Transtensional rifting in the late proto-Gulf of California near Bahía Kino, Sonora, México [M.S. thesis]: University of North Carolina, Chapel Hill, 122 p.

Bennett, S., 2011, Geothermal Potential of Transtensional Plate Boundaries: Geothermal Resources Council Transactions, v. 35, p. 703-707.

Bennett, S. E. K., 2013, The Role of Rift Obliquity in Formation of the Gulf of California [Ph.D thesis]: University of California, Davis, 220 p.

Bennett, S. E. K., and Oskin, M. E., 2014, Oblique rifting ruptures continents: Example from the Gulf of California shear zone: Geology, v. 42, no. 3, p. 215-218.

Bennett, S. E. K., Oskin, M. E., Dorsey, R. J., Iriondo, A., and Kunk, M. J., 2015, Stratigraphy and structural development of the southwest Isla Tiburón marine basin: Implications for latest Miocene tectonic opening and flooding of the northern Gulf of California: Geosphere.

Bennett, S. E. K., Oskin, M. E., and Iriondo, A., 2013, Transtensional rifting in the protoGulf of California, near Bahía Kino, Sonora, México: Geological Society of America Bulletin, v. 125, no. 11/12, p. 1752-1782.

Bialas, R. W., and Buck, W. R., 2009, How sediment promotes narrow rifting: Application to the Gulf of California: Tectonics, v. 28, no. TC4014, doi:10.1029/2008TC002394.

Boehm, M. C., 1984, An overview of the lithostratigraphy, biostratigraphy, and paleoenvironments of the late Neogene San Felipe Marine Sequence, Baja 
California, Mexico, in Frizzell, V. A., ed., Geology of the Baja California Peninsula, Volume 39: Los Angeles, California, Society of Economic Paleontologists and Mineralogists, Pacific Section, p. 253-265.

Bonini, M., Souriot, T., Boccaletti, M., \& Brun, J. P., 1997, Successive orthogonal and oblique extension episodes in a rift zone: Laboratory experiments with application to the Ethiopian Rift. Tectonics, v. 16, no. 2, p. 347-362.

Brady, R., Wernicke, B., and Fryxell, J., 2000, Kinematic evolution of a large-offset continental normal fault system, South Virgin Mountains, Nevada: Geological Society of America Bulletin, v. 112, no. 9, p. 1375-1397.

Brune, S., Popov, A., and Sobolev, S. V., 2012, Modeling suggests that oblique extension facilitates rifting and continental break-up: Journal of Geophysical Research, v. 117.

Buck, R. W., 1991, Modes of continental extension: Journal of Geophysical Research, v. 96, p. 20161-20178.

Buck, W. R., Lavier, L. L., Poliakov, A. N. B., Rohr, K., Jackson, J., Chadwick, A., Osmaston, M., Kusznir, N., Brun, J.-P., Roberts, A., and Geli, L., 1999, How to Make a Rift Wide: Philosophical Transactions: Mathematical, Physical and Engineering Sciences, v. 357, no. 1753, p. 671-693.

Busby, C. J., Koerner, A., Hagan, J., and Andrews, G., 2012, Sierra Crest graben: a Miocene Walker Lane Pull-apart in the Ancestral Cascades Arc at Sonora Pass, in Hughes, N., and Hayes, G., eds., Geological Excursions, Sonora Pass Region of the Sierra Nevada, Far Western Section, National Association of Geoscience Teachers field guide, p. 8-36. 
Carreño, A. L., 1992, Neogene microfossils from the Santiago Diatomite, Baja California Sur, Mexico: Paleontología Mexicana, v. 59.

Chester, F. M., 1995, A Rheologic Model For Wet Crust Applied to Strike-slip Faults: Journal of Geophysical Research-Solid Earth, v. 100, no. B7, p. 13033-13044.

Christie-Blick, N., and Biddle, K. T., 1985, Deformation and basin formation along strike-slip faults, in Biddle, K. T., and Christie-Blick, N., eds., Strike-slip deformation, Basin Formation, and Sedimentation, Volume SEPM Special Publication, p. 1-34.

Clifton, A. E., and Schlische, R. W., 2001, Nucleation, growth, and linkage of faults in oblique rift zones: Results from experimental clay models and implications for maximum fault size: Geology, v. 29, no. 5, p. 455-458.

Clifton, A. E., Schlische, R. W., Withjack, M. O., and Ackermann, R. V., 2000, Influence of rift obliquity on fault-population systematics: results of experimental clay models: Journal of Structural Geology, v. 22, p. 1491-1509.

Corti, G., Bonini, M., Innocenti, F., Manetti, P., \& Mulugeta, G., 2001, Centrifuge models simulating magma emplacement during oblique rifting. Journal of Geodynamics, v. 31, no. 5, p. 557-576.

Crowell, J. C., 1974, Sedimentation Along the San Andreas Fault California, in Dott, R.H. Jr. and Shaver, R.H. eds., Modern and ancient geosynclincal sedimentation: Soc. Econ. Paleontologists and Mineralogists Spec. Pub. 19, p.292-303.

Darin, M. H., Dorsey, R. J., Bennett, S. E. K., Oskin, M. E., Iriondo, A., and Kunk, M. J., this volume, Late Miocene Extension in Coastal Sonora, México: Implications for 
the Evolution of Dextral Shear in the Proto-Gulf of California Oblique Rift: Tectonophysics.

Dokka, R. K., and Travis, C. J., 1990, Late Cenozoic strike- slip faulting in the Mojave Desert, California. Tectonics, v. 9, no. 2, p. 311-340.

Dorsey, R. J., Fluette, A., McDougall, K., Housen, B. A., Janecke, S. U., Axen, G. J., and Shirvell, C. R., 2007, Chronology of Miocene-Pliocene deposits at Split Mountain Gorge, Southern California: A record of regional tectonics and Colorado River evolution: Geology, v. 35, no. 1, p. 57-60.

Dorsey, R. J., 2010, Sedimentation and crustal recycling along an active oblique-rift margin: Salton Trough and northern Gulf of California: Geology, v. 38, no. 5, p. 443-446.

Dorsey, R. J., Housen, B. A., Janecke, S. U., Fanning, C. M., and Spears, A. L. F., 2011, Stratigraphic record of basin development within the San Andreas fault system: Late Cenozoic Fish Creek-Vallecito basin, southern California: Geological Society of America Bulletin, v. 123, no. 5-6, p. 771-793.

England, P., 1983, Constraints on extension of continental lithosphere: Journal of Geophysical Research, v. 88, p. 1145-1152.

Escalona-Alcázar, F. J., Delgado-Argote, L. A., López-Martínez, M., and RendónMárquez, G., 2001, Late Miocene volcanism and marine incursions in the San Lorenzo Archipelago, Gulf of California, Mexico: Revista Mexicana de Ciencias Geologicas, v. 18, no. 2, p. 111-128. 
Faulds, J. E., Henry, C. D., and Hinz, N. H., 2005, Kinematics of the northern Walker Lane: An incipient transform fault along the Pacific-North American plate boundary: Geology, v. 33, no. 6, p. 505-508.

Fenby, S. S., and Gastil, R. G., 1991, Geologic-Tectonic Map of the Gulf of California and Surrounding Areas, in Dauphin, J. P., and Simoneit, B. R. T., eds., AAPG Memoir 47: The Gulf and Peninsular Province of the Californias, Volume 47, p. 7983.

Ferrari, L., López-Martínez, M., Orozco-Esquivel, T., Bryan, S. E., Duque-Trujillo, J., Lonsdale, P., \& Solari, L., 2013, Late Oligocene to Middle Miocene rifting and synextensional magmatism in the southwestern Sierra Madre Occidental, Mexico: The beginning of the Gulf of California rift. Geosphere, GES00925-1.

Fletcher, J. M., Grove, M., Kimbrough, D., Lovera, O., and Gehrels, G. E., 2007, Ridgetrench interactions and the Neogene tectonic evolution of the Magdalena shelf and southern Gulf of California: Insights from detrital zircon U-Pb ages from the Magdalena fan and adjacent areas: Geological Society of America Bulletin, v. 119, no. $11 / 12$, p. 1313-1336.

Forsyth, D. W., 1992, Finite extension and low-angle normal faulting: Geology, v. 20, p. 27-30.

Fuis, G. S., Mooney, W. D., Healy, J. H., McMechan, G. A., and Lutter, W. J., 1984, A seismic refraction survey of the Imperial Valley Region, California: Journal of Geophysical Research, v. 89, p. 1165-1189. 
Gans, P., Magmatic-tectonic interactions in the Gulf extensional province: Insights from the Sonoran margin, in Proceedings Lithospheric Rupture in the Gulf of CaliforniaSalton Trough Region - NSF Margins RCL Workshop, Ensenada, Mexico, 2006.

Gans, P. B., 1997, Large-magnitude Oligo-Miocene extension in southern Sonora: Implications for the tectonic evolution of northwest Mexico: Tectonics, v. 16, no. 3, p. $388-408$.

Gastil, R. G., and Fenby, S. S., 1991, Detachment faulting as a mechanism for tectonically filling the Gulf of California during dilation, in Dauphin, J. P., and Simoneit, B. R. T., eds., AAPG Memoir 47: The Gulf and Peninsular Province of the Californias, Volume 47, p. 371-375.

Gastil, R. G., and Krummenacher, D., 1977a, Reconnaissance geologic map of coastal Sonora between Puerto Lobos and Bahia Kino, GSA Map and Chart Series MC-16: Geological Society of America, scale 1:150,000.

-, 1977b, Reconnaissance geology of coastal Sonora between Puerto Lobos and Bahia Kino: Geological Society of America Bulletin, v. 88, no. 2, p. 189-198.

Gastil, R. G., Lemone, D. V., and Stewart, W. J., 1973, Permian fusulinids from near San Felipe, Baja California: American Association of Petroleum Geologists Bulletin, v. 57, no. 4, p. 746-747.

Gastil, R. G., Neuhaus, J., Cassidy, M., Smith, J. T., Ingle, J. C., and Krummenacher, D., 1999, Geology and paleontology of southwestern Isla Tiburón, Sonora, Mexico: Revista Mexicana de Ciencias Geologicas, v. 16, no. 1, p. 1-34.

González-Fernández , A., Danobeitia, J. J., Deldago-Argote, L., Michaud, F., Cordoba, D., and Bartolome, R., 2005, Mode of extension and rifting history of upper Tiburon 
and upper Delfin basins, northern Gulf of California: Journal of Geophysical Research, v. 110, p. 1-17.

Gonzalez-Leon, C. M., Valencia, V. A., Lopez-Martinez, M., Bellon, H., ValenciaMoreno, M., and Calmus, T., 2010, Arizpe sub-basin: A sedimentary and volcanic record of Basin and Range extension in north-central Sonora, Mexico: Revista Mexicana de Ciencias Geologicas, v. 27, no. 2, p. 292-312.

Hamilton, W., 1961, Origin of the Gulf of California: Geological Society of America Bulletin, v. 72, no. 9, p. 1307-1318.

Hausback, B. P., 1984, Cenozoic volcanic and tectonic evolution of Baja California Sur, Mexico, in Frizzell, V. A., Jr., ed., Geology of the Baja California Peninsula, Volume 39: Los Angeles, California, Pacific Section of the Economic Paleontologists and Mineralogists, p. 219-236.

Heine, C., and Brune, S., 2014, Oblique rifting of the Equatorial Atlantic: Why there is no Saharan Atlantic Ocean: Geology, v. 42, no. 3, p. 211-214.

Henry, C., and Faulds, J., The Walker Lane and Gulf of California: Related Expressions of Pacific-North America Plate Boundary Development, in Proceedings RCL-Cortez Workshop: Lithospheric Rupture in the Gulf of California-Salton Trough Region, Ensenada, Mexico, 2006.

Henry, C. D., and Aranda Gomez, J. J., 1992, The real southern basin and range: Mid Cenozoic to Late Cenozoic extension in Mexico: Geology, v. 20, no. 8, p. 701-704.

Herman, S., 2013, A paleomagnetic investigation of vertical-axis rotations in coastal Sonora, Mexico: Evidence for distributed transtensional deformation during the Proto-Gulf shift from a subduction-dominated to transform-dominated plate 
boundary in the Gulf of California [M.S. thesis]: University of California, Santa Barbara, 39p.

Holt, J. W., Stock, J. M., and Holt, E. W., 2000, An age constraint on Gulf of California rifting from the Santa Rosalía basin, Baja California Sur, Mexico: GSA Bulletin, v. 112 , no. 4 , p. $540-549$.

Hopper, J. R., and Buck, W. R., 1996, The effect of lower crustal flow on continental extension and passive margin formation: Journal of Geophysical Research, v. 101, no. B9, p. 20,175-120,194.

Huismans, R. S., and Beaumont, C., 2003, Symmetric and asymmetric lithospheric extension: Relative effects of frictional-plastic and viscous strain softening: Journal of Geophysical Research, v. 108, no. B10.

Ingersoll, R. V., 1988, Tectonics of sedimentary basins: Geological Society of America Bulletin, v. 100, no. 11, p. 1704-1719.

Jackson, J. A., and White, N. J., 1989, Normal faulting in the upper continental crust: observations from regions of active extension: Journal of Structural Geology, v. 11, no. $1-2$, p. $15-\&$.

Karig, D. E., and Jensky, W., 1972, The Proto-gulf of California: Earth and Planetary Science Letters, v. 17, p. 169-174.

Kaus, B. J. P., and Podladchikov, Y. Y., 2006, Initiation of localized shear zones in viscoelastoplastic rocks: Journal of Geophysical Research, v. 111, no. B04412.

Kluesner, J. W., 2011, Marine Geophysical Study of Cyclic Sedimentation and Shallow Sill Intrusion in the Floor of the Central Gulf of California [PhD thesis]: University of California, San Diego, 213 p. 
Kohn, B. P., Fletcher, J., Grove, M., Lovera, O., Gleadow, A. J. W., and Foster, D. A., Cenozoic basement evolution and the timing of continental rifting, southern Gulf Extensional Province, Baja California Peninsula, Mexico: evidence from integrated thermochronology, in Proceedings Thermo2010 - 12th International Conference on Thermochronology, Glasgow, Scotland, 2010, p. 221-221.

Kusznir, N. J., and Park, R. G., 1987, The extensional strength of the continental lithosphere: its dependence on geothermal gradient, and crustal composition and thickness, in Coward, M. P., Dewey, J. F., and Hancock, P. L., eds., Continental Extension Tectonics, Volume Special Publication No 28, Geological Society.

Larson, R. L., Menard, H. W., and Smith, S. M., 1968, Gulf of California: a result of ocean floor spreading and transform faulting: Science, v. 161, p. 781-784.

Lavier, L. L., and Manatschal, G., 2006, A mechanism to thin the continental lithosphere at magma-poor margins: Nature, v. 440, p. 324-328.

Lavier, L. L., and Steckler, M. S., 1997, The effect of sedimentary cover on flexural strength of continental lithosphere: Nature, v. 389, p. 476-479.

Leloup, P. H., Ricard, Y., Battaglia, J., and Lacassin, R., 1999, Shear heating in continental strike-slip shear zones: model and field examples: Geophysical Journal International, v. 136, no. 1, p. 19-40.

Lewis, C. J., and Stock, J. M., 1998, Paleomagnetic evidence of localized vertical-axis rotation during Neogene extension of the Sierra San Fermín, northeastern Baja California, Mexico: JGR, v. 103, p. 2455-2470.

-, 1998, Late Miocene to recent transtensional tectonics in the Sierra San Fermín, northeastern Baja California, Mexico: J. Structural Geology, v. 20, p. 1043-1063. 
Lizarralde, D., Axen, G. J., Brown, H. E., Fletcher, J. M., González-Fernández, A., Harding, A. J., Holbrook, W. S., Kent, G. M., Paramo, P., Sutherland, F., and Umhoefer, P. J., 2007, Variation in styles of rifting in the Gulf of California: Nature, v. 448, p. $466-469$.

Lonsdale, P., 1989, Geology and tectonic history of the Gulf of California, in Winterer, E. L., Hussong, D. M., and Decker, R. W., eds., The Eastern Pacific Ocean and Hawaii, Geology of North America, Volume N: Boulder, CO, Geological Society of America, p. 499-521.

Louden, K. E., and Chian, D., 1999, The deep structure of non-volcanic rifted continental margins: Philosophical Transactions of the Royal Society of London, v. 357, p. 767804.

Lourens, L., Hilgen, F., Shackleton, N. J., Laskar, J., and Wilson, D., 2004, The Neogene Period, in Gradstein, F. M., Ogg, J. G., and Smith, A. G., eds., A Geologic Time Scale 2004.

Ludwig, K. R., 2003, Mathematical-statistical treatment of data and errors for Th-230/U geochronology: Uranium-Series Geochemistry, v. 52, p. 631-656.

Lugo-Zazueta, R. E., Kohn, B. P., Gleadow, A. J. W., Calmus, T., Ramos-Velázquez, E., and Fletcher, J., Low temperature thermochronology of the eastern Gulf of California: a sheared continental margin, Sonora, Mexico, in Proceedings Thermo2010 - 12th International Conference on Thermochronology, Glasgow, Scotland, 2010, p. 137-137. 
Mark, C., Gupta, S., Carter, A., Mark, D. F., Gautheron, C., \& Martín, A., 2014, Rift flank uplift at the Gulf of California: No requirement for asthenospheric upwelling. Geology, v. 42, no. 3, p. 259-262.

Mar-Hernández, E., González-Escobar, M., and Martín-Barajas, A., 2012, Tectonic framework of Tiburon Basin, Gulf of California, from seismic reflection evidence: International Geology Review, v. 54, no. 11, p. 1271-1283.

Martín-Barajas, A., Vazquez-Hernandez, S., Carreno, A.L., Helenes, J., Suarez-Vidal, F., and Alvarez-Rosales, J., 2001, Late Neogene stratigraphy and tectonic control on facies evolution in the Laguna Salada Basin, northern Baja California, Mexico: Sedimentary Geology, v. 144, p. 5-35.

Martín-Barajas, A., González-Escobar, M., Fletcher, J. M., Pacheco, M., Oskin, M., and Dorsey, R., 2013, Thick deltaic sedimentation and detachment faulting delay the onset of continental rupture in the Northern Gulf of California: Analysis of seismic reflection profiles: Tectonics, v. 32, p. 18.

McCloy, C., Ingle, J. C., \& Barron, J. A., 1988, Neogene stratigraphy, foraminifera, diatoms, and depositional history of Maria Madre Island, Mexico: evidence of early Neogene marine conditions in the southern Gulf of California. Marine Micropaleontology, v. 13, p. 193-212.

McDowell, F. W., Roldan-Quintana, J., and Amaya-Martinez, R., 1997, Interrelationship of sedimentary and volcanic deposits associated with tertiary extension in Sonora, Mexico: GSA Bulletin, v. 109, no. 10, p. 1349-1360.

Miller, N. C., and Lizarralde, D., 2013, Thick evaporites and early rifting in the Guaymas Basin, Gulf of California: Geology, v. 41, no. 2, p. 283-286. 
Molina-Cruz, A., 1994, Biostratigraphy and paleoceanographic significance of the radiolarians from the protomouth of the Gulf of California: Ciencias Marinas, v. 20, no. 4 , p. 441-465.

Neuhaus, J., 1989, Volcanic and nonmarine stratigraphy of southwest Isla Tiburón, Gulf of California, Mexico [M.S. thesis]: San Diego State University, 170 p.

Nicholson, C., Sorlien, C. C., Atwater, T., Crowell, J. C., and Luyendyk, B. P., 1994, Microplate capture, rotation of the western Transverse Ranges, and initiation of the San Andreas transform as a low-angle fault system: Geology, v. 22, p. 491-495.

Niño-Estrada, L., Iriondo, A., García-Flores, R., McDowell, F. W., Izaguirre, A., Bennett, S. E. K., and Oskin, M. E., Edades Cretácicas de rocas batolíticas del Isla Tiburón, Golfo de California: Geocrhonología U-Pb en zircones mediante técnicas de ablación láser e ICP-MS, in Proceedings Unión Geofísica Mexicana Reunión Anual, Puerto Vallarta, Mexico, 2014.

Oskin, M., 2002, Tectonic Evolution of The Northern Gulf of California, Mexico, Deduced from Conjugate Rifted Margins of the Upper Delfín BasinPh.D.]: California Institute of Technology, $481 \mathrm{p}$.

Oskin, M., Stock, J., and Martín-Barajas, A., 2001, Rapid localization of Pacific-North America plate motion in the Gulf of California: Geology, v. 29, no. 5, p. 459-462.

Oskin, M., and Stock, J. M., 2003a, Marine incursion synchronous with plate-boundary localization in the Gulf of California: Geology, v. 31, p. 23-26.

-, 2003b, Pacific-North America plate motion and opening of the Upper Delfín basin, northern Gulf of California: Geological Society of America Bulletin, v. 115, p. $1173-1190$. 
Pacheco, M., Martín-Barajas, A., Elders, W., Espinosa-Cardena, J. M., Helenes, J., and Segura, A., 2006, Stratigraphy and structure of the Altar basin of NW Sonora: Implications for the history of the Colorado River delta and the Salton trough: Revista Mexicana de Ciencias Geologicas, v. 23, no. 1, p. 22.

Powell, R. E., \& Weldon, R. J., 1992, Evolution of the San Andreas fault: Annual Reviews of Earth and Planetary Science, v. 20, p. 431-468.

Ramos-Velázquez, E., Calmus, T., Valencia, V., Iriondo, A., Valencia-Moreno, M., and Bellon, H., 2008, U-Pb and 40Ar/39Ar geochronology of the coastal Sonora batholith: New insights on Laramide continental arc magmatism: Revista Mexicana de Ciencias Geológicas, v. 25, no. 2, p. 314-333.

Sanderson, D., and Marchini, R.D., 1984, Transpression: Journal of Structural Geology, v. 6, p. $449-458$.

Seiler, C., 2009. Structural and thermal evolution of the Gulf Extensional Province in Baja California, Mexico: Implications for Neogene rifting and opening of the Gulf of California, [PhD thesis] The University of Melbourne, 307 p.

Seiler, C., Fletcher, J., Kohn, B. P., Gleadow, A. J. W., and Raza, A., 2011, Lowtemperature thermochronology of northern Baja California, Mexico: Decoupled slipexhumation gradients and delayed onset of oblique rifting across the Gulf of California: Tectonics, v. 30, no. TC3004.

Seiler, C., Fletcher, J. M., Quigley, M. C., Gleadow, A. J. W., and Kohn, B. P., 2010, Neogene structural evolution of the Sierra San Felipe, Baja California: Evidence for proto-Gulf transtension in the Gulf Extensional Province?: Tectonophysics, v. 488, p. 87-109. 
Skinner, L. A., Umhoefer, P. J., \& Kluesner, J. W., 2012, The Proto Southern Gulf of California represented by GIS Plate Tectonic Reconstructions, AGU Fall Meeting Abstracts.

Skinner, S., Stock, J., and Martín-Barajas, A., Characterization of the Tuff of San Felipe on Isla Angel de la Guarda, Baja California, Mexico, in Proceedings Geological Society of America, Cordilleran Section Meeting, Queretaro, Mexico, 2012.

Slama, J., Kosler, J., Condon, D. J., Crowley, J. L., Gerdes, A., Hanchar, J. M., Horstwood, M. S. A., Morris, G. A., Nasdala, L., Norberg, N., Schaltegger, U., Schoene, B., Tubrett, M. N., and Whitehouse, M. J., 2008, Plesovice zircon - A new natural reference material for $\mathrm{U}-\mathrm{Pb}$ and $\mathrm{Hf}$ isotopic microanalysis: Chemical Geology, v. 249, no. 1-2, p. 1-35.

Smith, J. T., Smith, J. G., Ingle, J. C. J., Gastil, R. G., Boehm, M. C., Roldan, Q. J., and Casey, R. E., Fossil and K-Ar age constraints on upper middle Miocene conglomerate, SW Isla Tiburón, Gulf of California, in Proceedings Geological Society of America, Cordilleran Section, 81st annual meeting, Vancouver, British Columbia, 1985, Volume 17, p. 409.

Stock, J., Martín-Barajas, A., Martinez-Lopez, M., and Chapman, A., 2008, Net slip across the Ballenas Transform fault measured from offset ignimbrite deposits: American Geophysical Union, Fall Meeting, abstract \#T11A-1853.

Stock, J., Paz-Moreno, F. A., Martin, K., and Lin, D., 2006, The 12.5 Ma Tuff of San Felipe: a major structural marker horizon in northwestern Mexico, in Proceedings of Lithospheric Rupture in the Gulf of California-Salton Trough Region - NSF Margins RCL Workshop, Ensenada, Mexico. 
Stock, J. M., and Hodges, K. V., 1989, Pre-Pliocene extension around the Gulf of California and the transfer of Baja California to the Pacific Plate: Tectonics, v. 8, no. 1, p. 99-115.

Stock, J. M., Lewis, C. J., and Nagy, E. A., 1999, The Tuff of San Felipe: an extensive middle Miocene pyroclastic flow deposit in Baja California, Mexico: Journal of Volcanology and Geothermal Research, v. 93, p. 53-74.

Stock, J. M., and Molnar, P., 1988, Uncertainties and implications of the Late Cretaceous and Tertiary position of North America relative to the Farallon, Kula, and Pacific plates: Tectonics, v. 7 , no. 6 , p. 1339-1384.

Sutherland, F. H., Kent, G. M., Harding, A. J., Umhoefer, P. J., Driscoll, N. W., Lizarralde, D., Fletcher, J. M., Axen, G. J., Holbrook, W. S., González-Fernández , A., and Lonsdale, P., 2012, Middle Miocene to early Pliocene oblique extension in the southern Gulf of California: Geosphere, v. 8, no. 4, p. 752-770.

Tucholke, B. E., Lin, J., and Kleinrock, M. C., 1998, Megamullions and mullion structure defining oceanic metamorphic core complexes on the mid-Atlantic ridge: Journal of Geophysical Research-Solid Earth, v. 103, no. B5, p. 9857-9866.

Umhoefer, P. J., 2011, Why did the Southern Gulf of California rupture so rapidly?Oblique divergence across hot, weak lithosphere along a tectonically active margin: GSA Today, p. 4-10.

Umhoefer, P. J., Dorsey, R. J., Willsey, S., Mayer, L., and Renne, P., 2001, Stratigraphy and geochronology of the Comondú Group near Loreto, Baja California Sur, Mexico: Sedimentary Geology, v. 144, p. 125-147. 
Valencia-Moreno, M., Ruiz, J., Ochoa-Landín, L., Martínez-Serrano, R., and VargasNavarro, P., 2003, Geochemistry of the Coastal Sonora batholith, Northwestern Mexico: Can. J. Earth Sci., v. 40, p. 819-831.

van Wijk, J. W., 2005, Role of weak zone orientation in continental lithosphere extension: Geophysical Research Letters, v. 32, no. 2.

-, Numerical Models of Oblique Rifting: Application to the Gulf of California, in Proceedings AGU Spring Meeting 2007.

Vidal-Solano, J., Moreno, F. A. P., Alexander Iriondo c, d., Demant, A., and Cochemé, J.-J., 2005, Middle Miocene peralkaline ignimbrites in the Hermosillo region (Sonora, Mexico): Geodynamic implications: C.R. Geoscience, v. 337, p. 14211430.

Vidal-Solano, J. R., Lozano Santa Cruz, R., Zamora, O., Mendoza-Cordova, A., and Stock, J. M., 2013, Geochemistry of the extensive peralkaline pyroclastic flow deposit of NW Mexico, based on conventional and handheld X-ray fluorescence. Implications in a regional context: Journal of Iberian Geology, v. 39, no. 1, p. 121130.

Wilson, D., McCrory, P., and Stanley, R., 2005, Implications of volcanism in coastal California for the Neogene deformation history of western North America: Tectonics, v. 24.

Withjack, M. O., and Jamison, W. R., 1986, Deformation produced by oblique rifting: Tectonophysics, v. 126, p. 99-124.

Xie, X., and Heller, P. L., 2009, Plate tectonics and basin subsidence history: Geological Society of America Bulletin, v. 121, no. 1-2, p. 55-64. 


\section{Ał녈 Figures-resubmission}

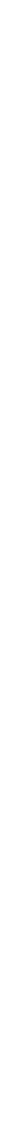


Figure 2

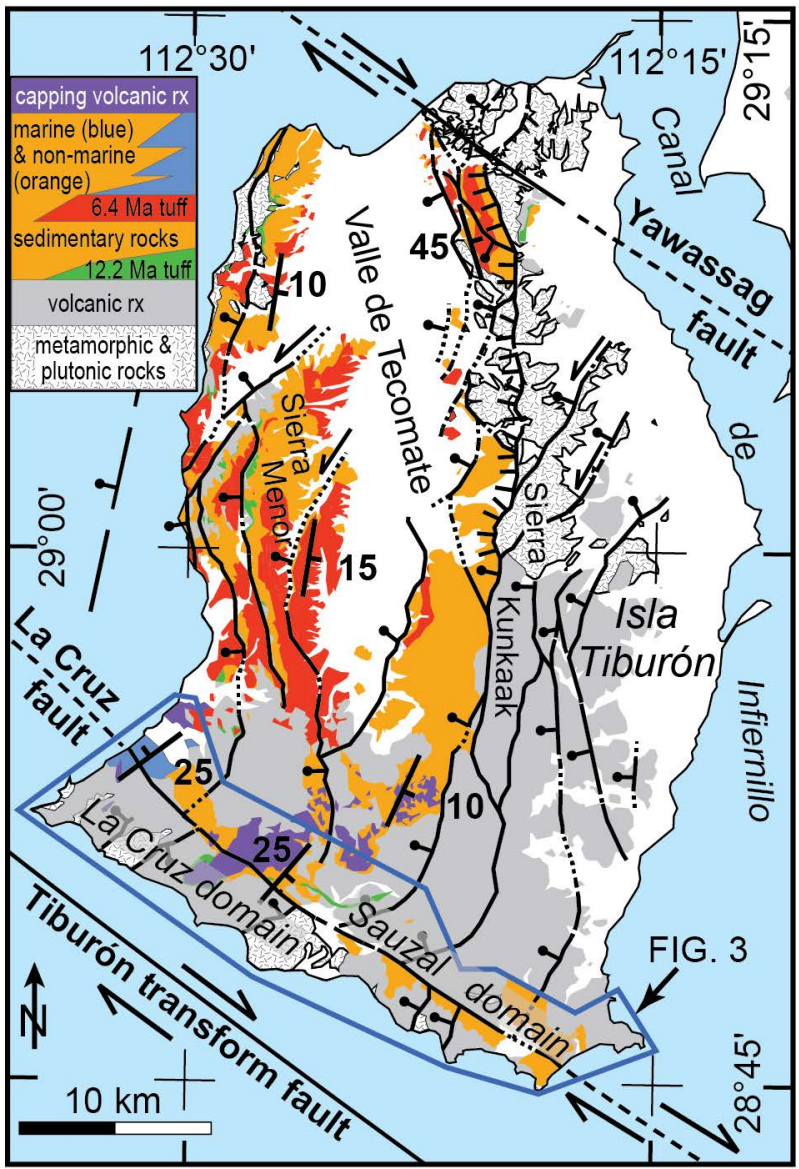







FIGURE 4

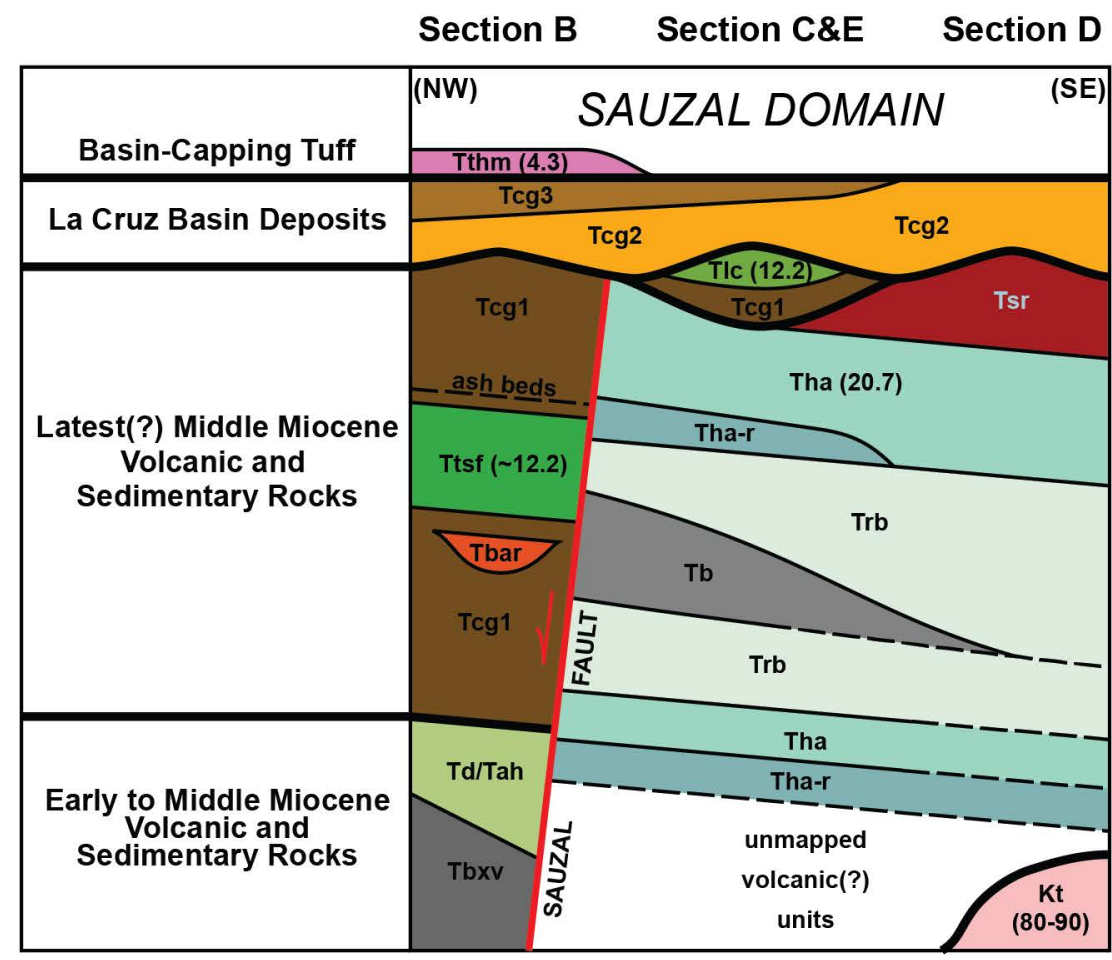

LA CRUZ FAULT

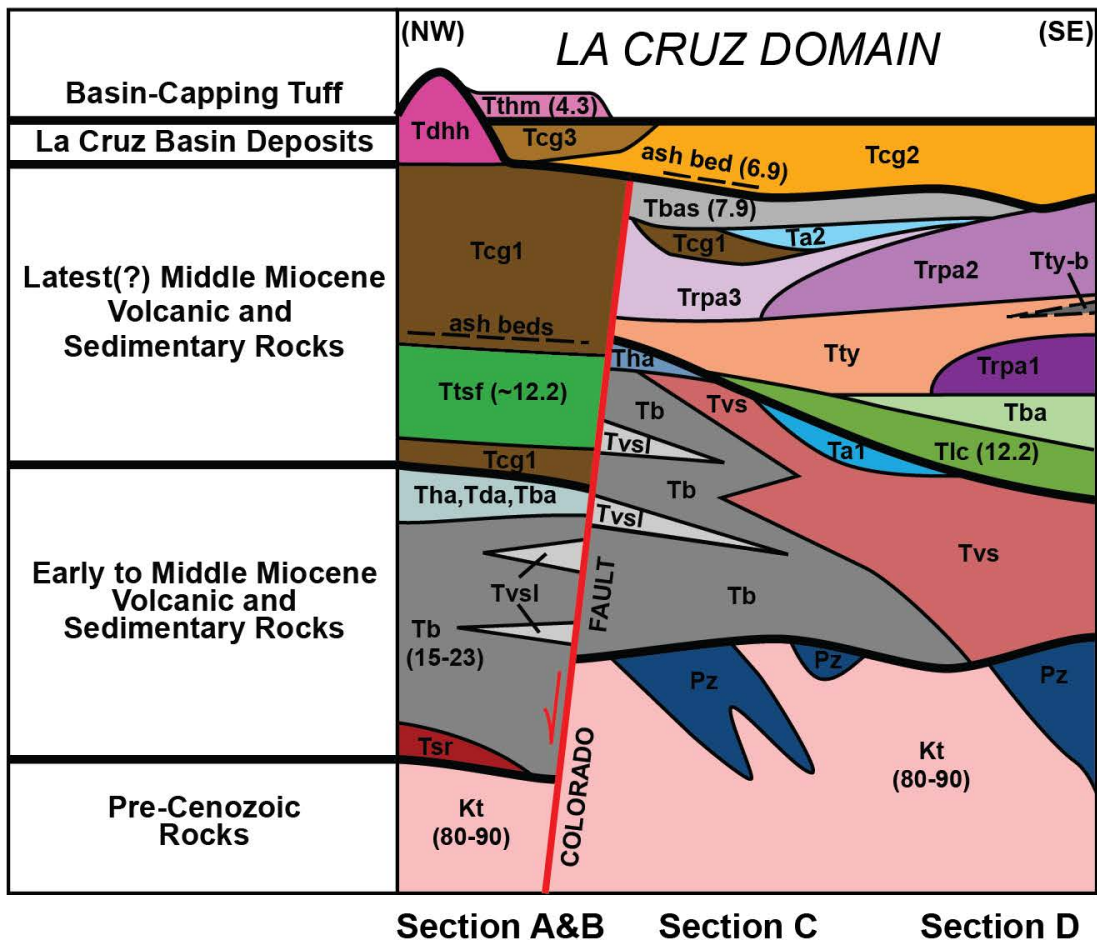


A
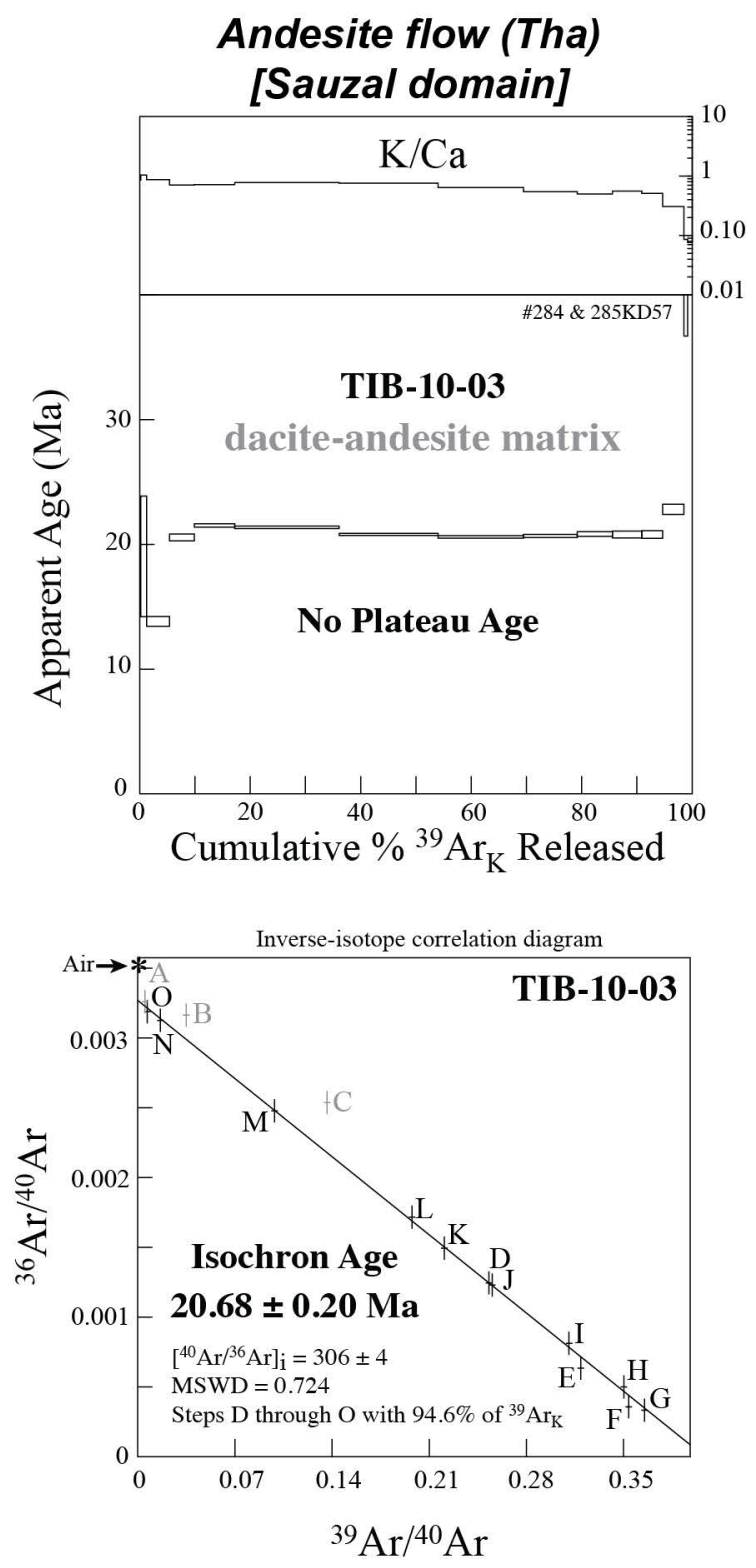

B
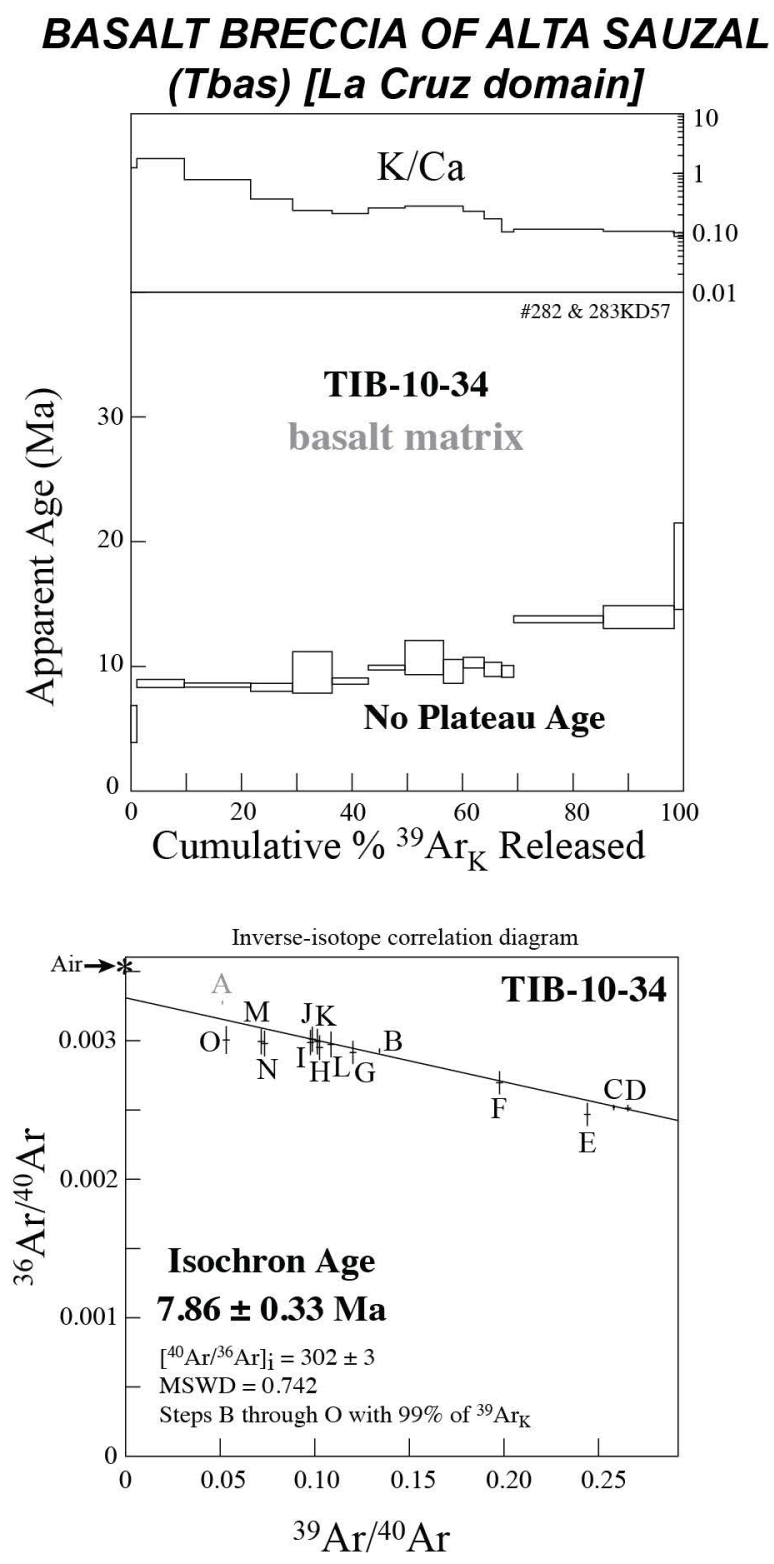

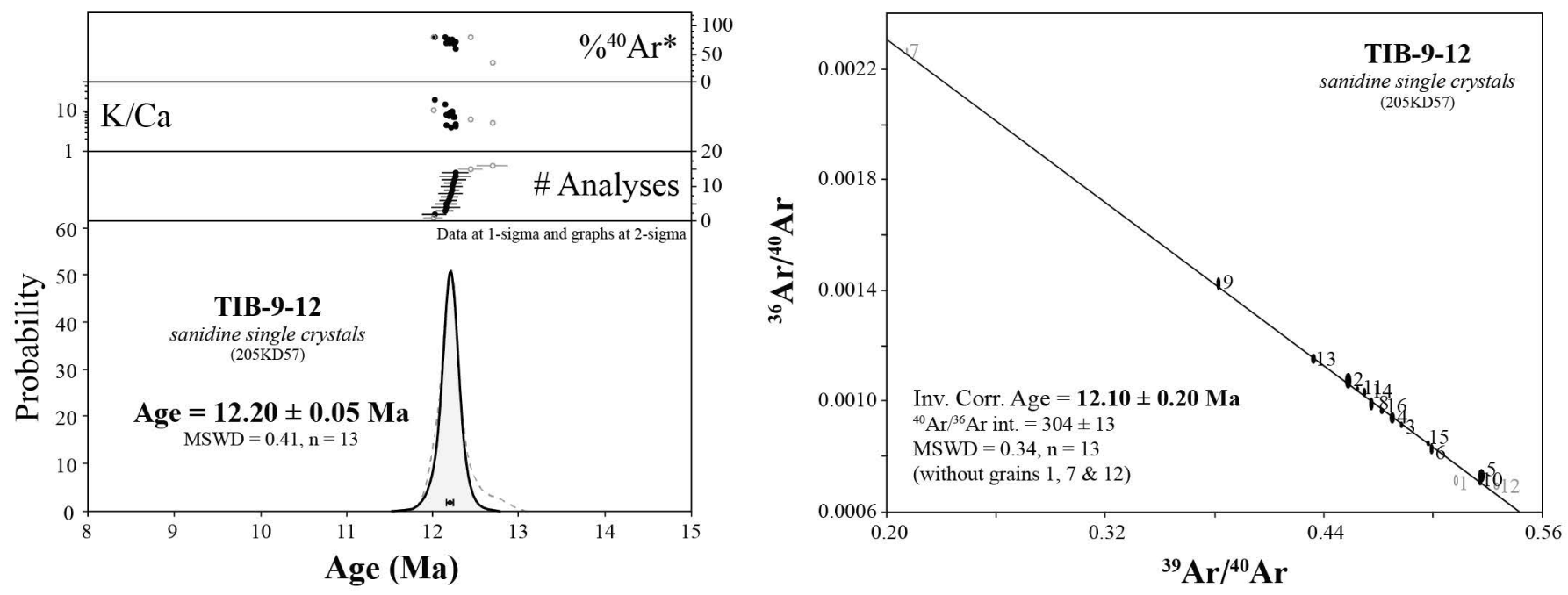

B TUFF OF ENSENADA DE LA CRUZ (TIC) [La Cruz domain]
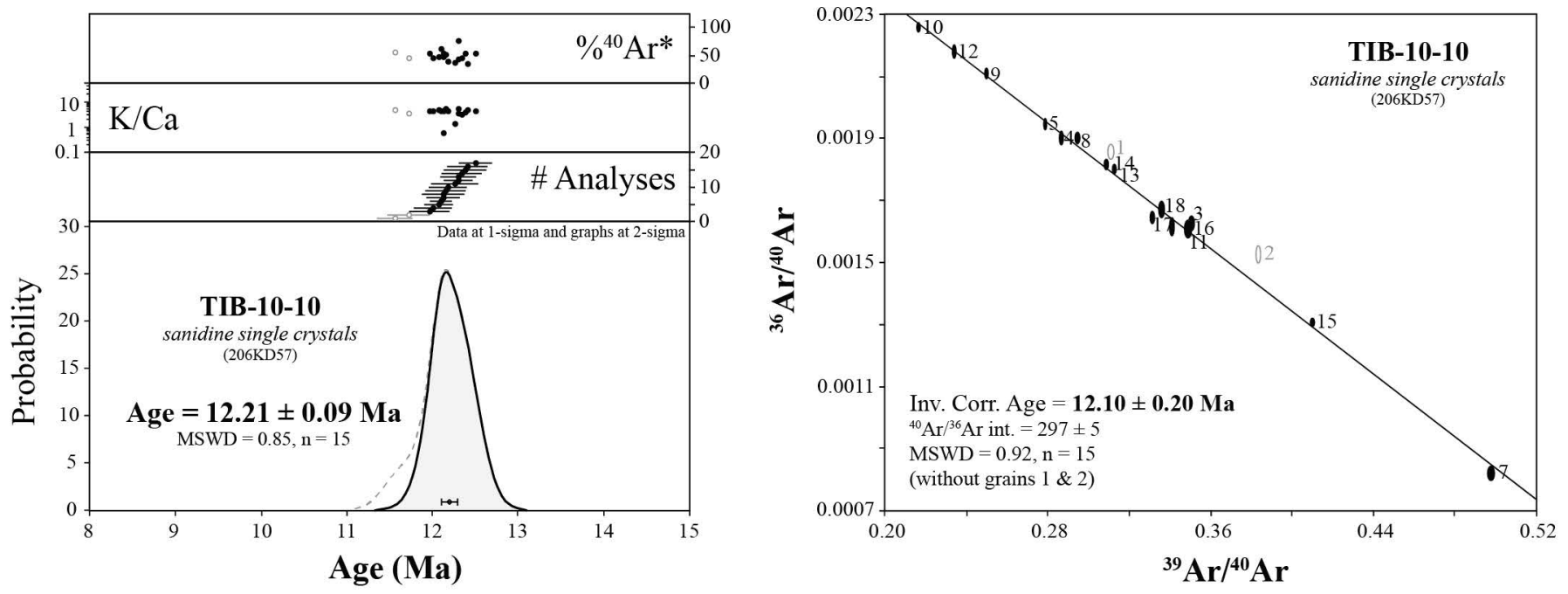

\section{TUFF OF SAN FELIPE (Ttsf) [Sauzal domain]}
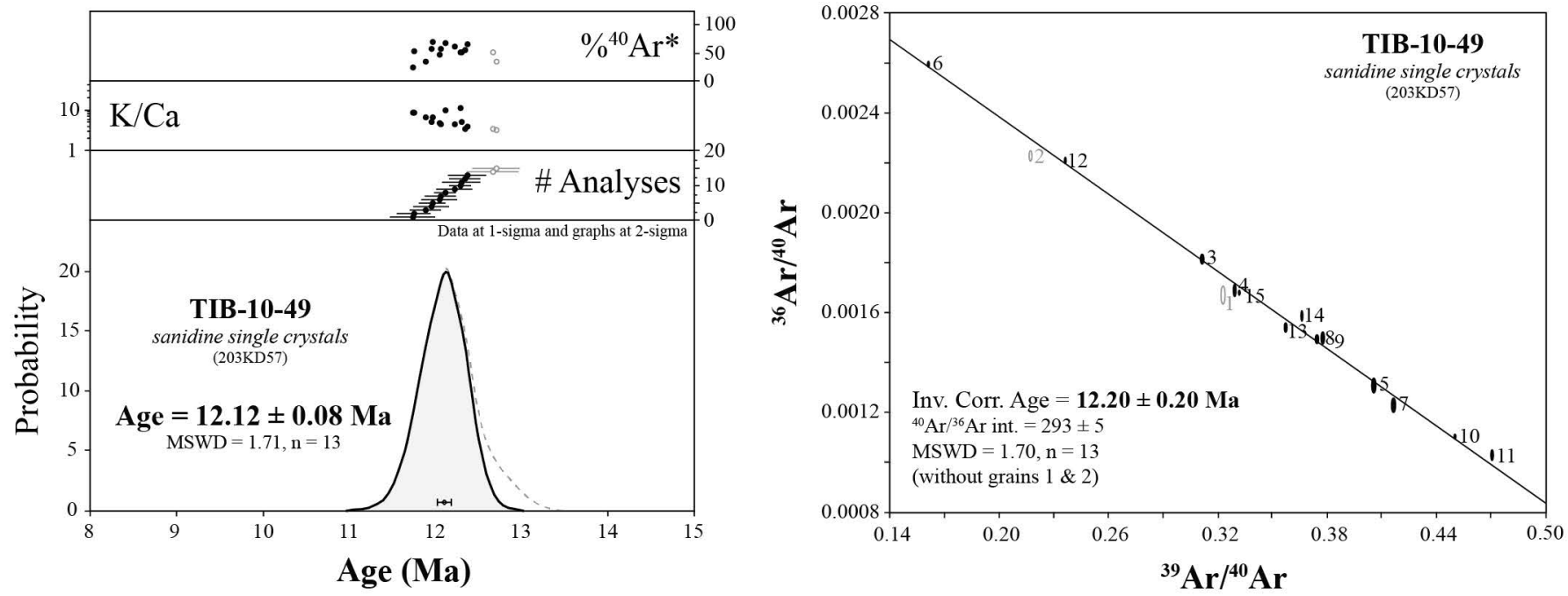

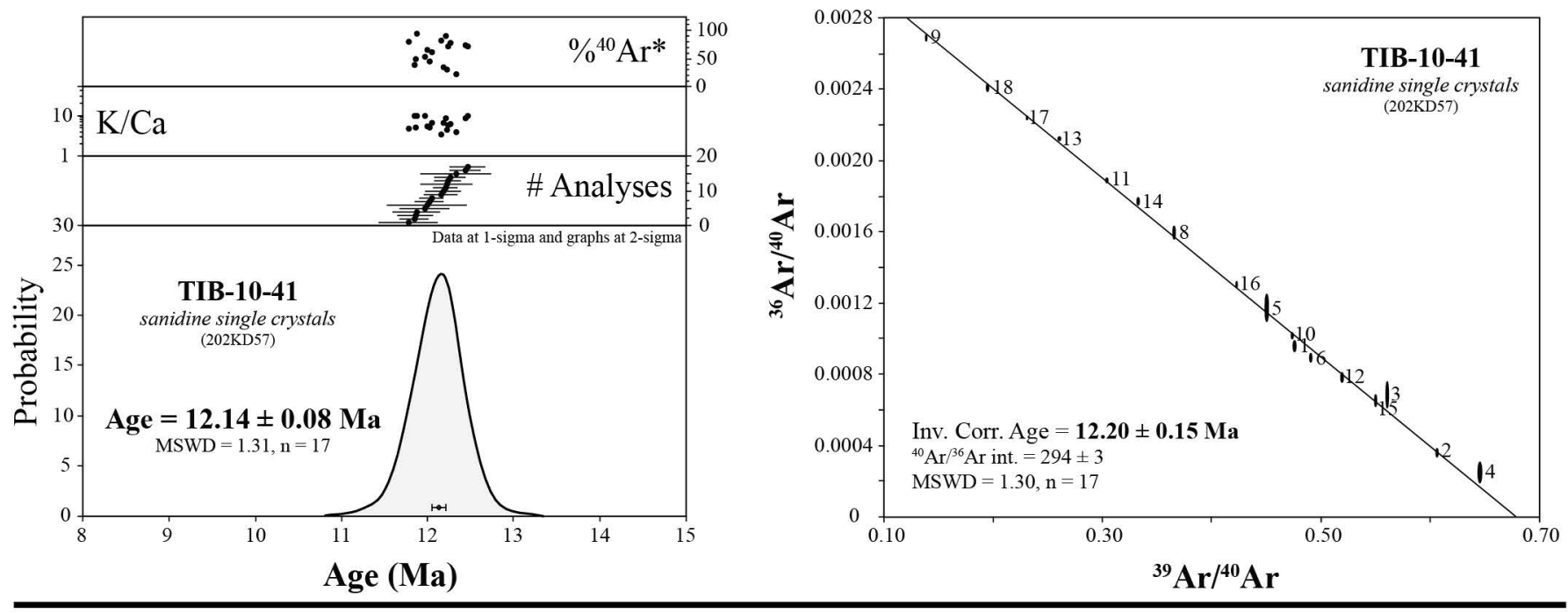

E

TUFF OF ENSENADA DE LA CRUZ (TIC) [La Cruz fault zone]
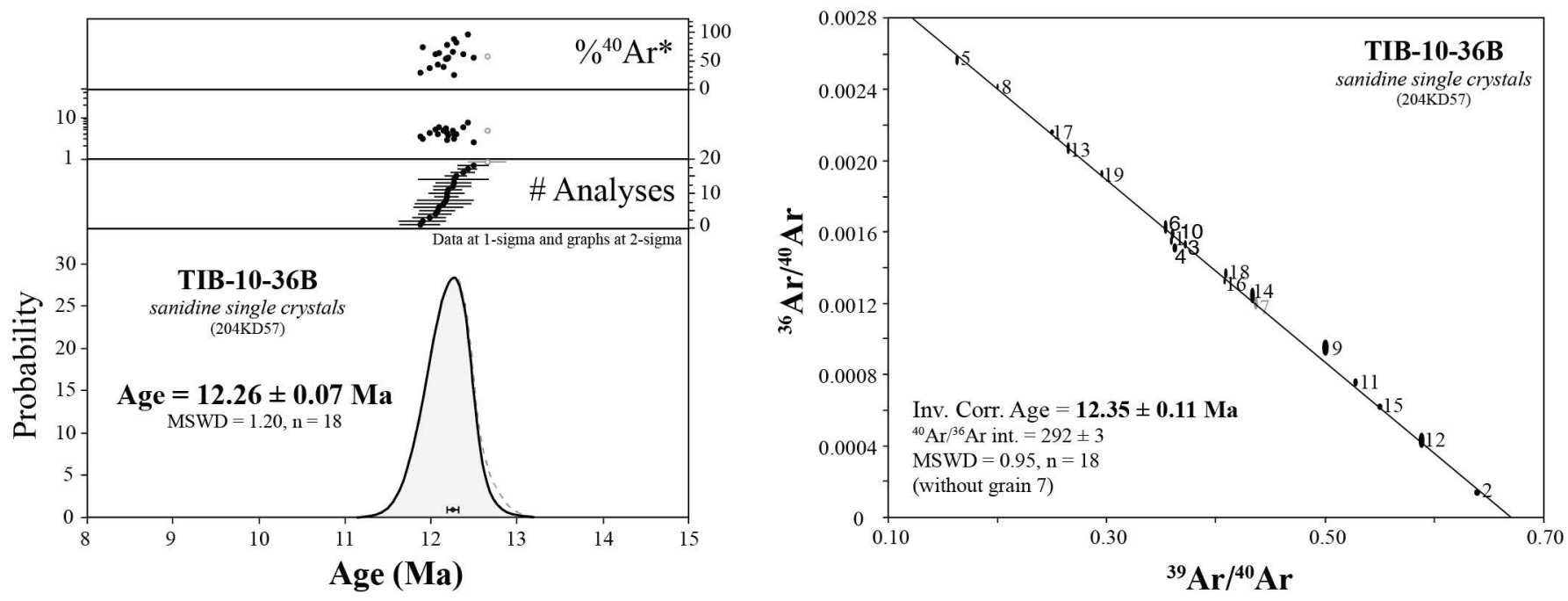

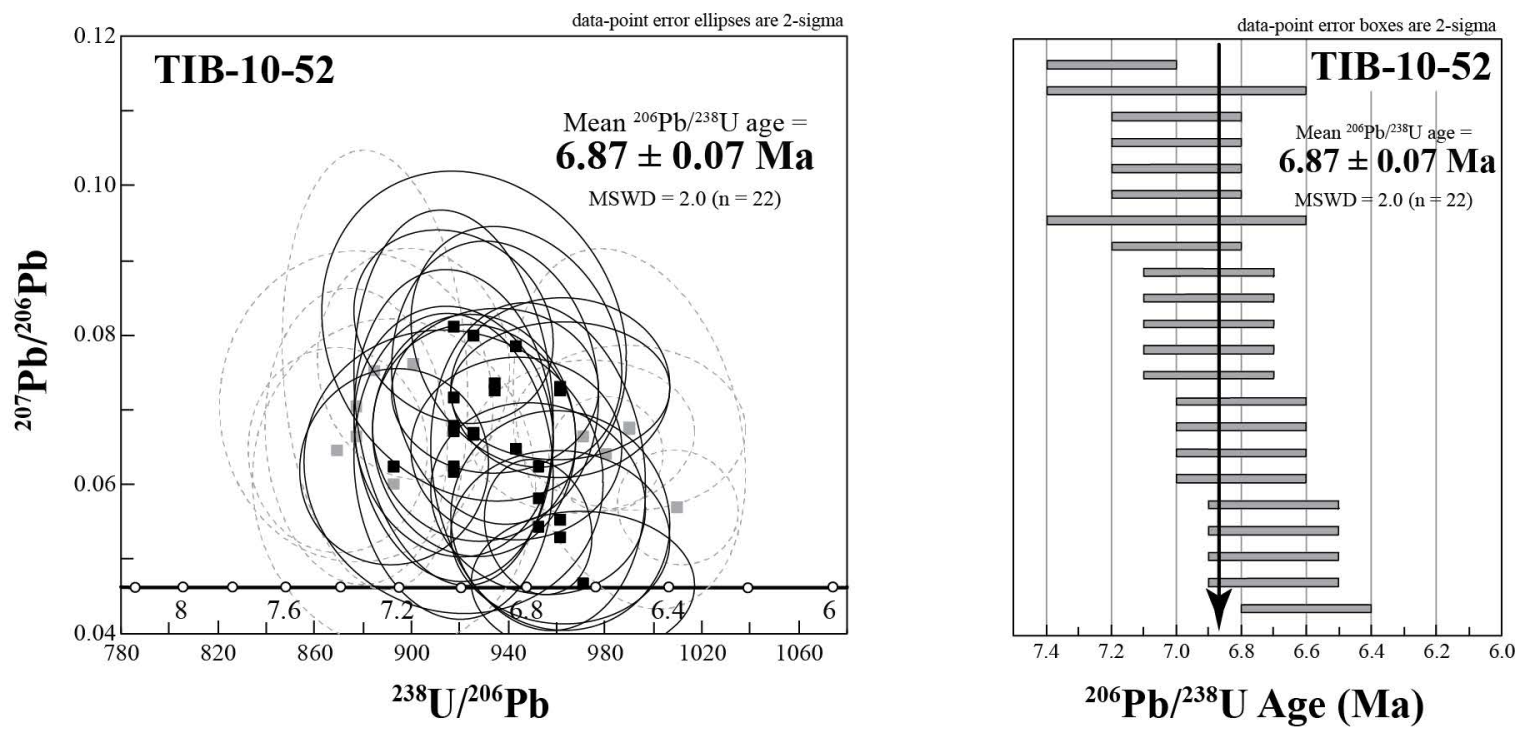

B

TUFFS OF HIPAT MESA (Tthm1) [capping La Cruz basin]
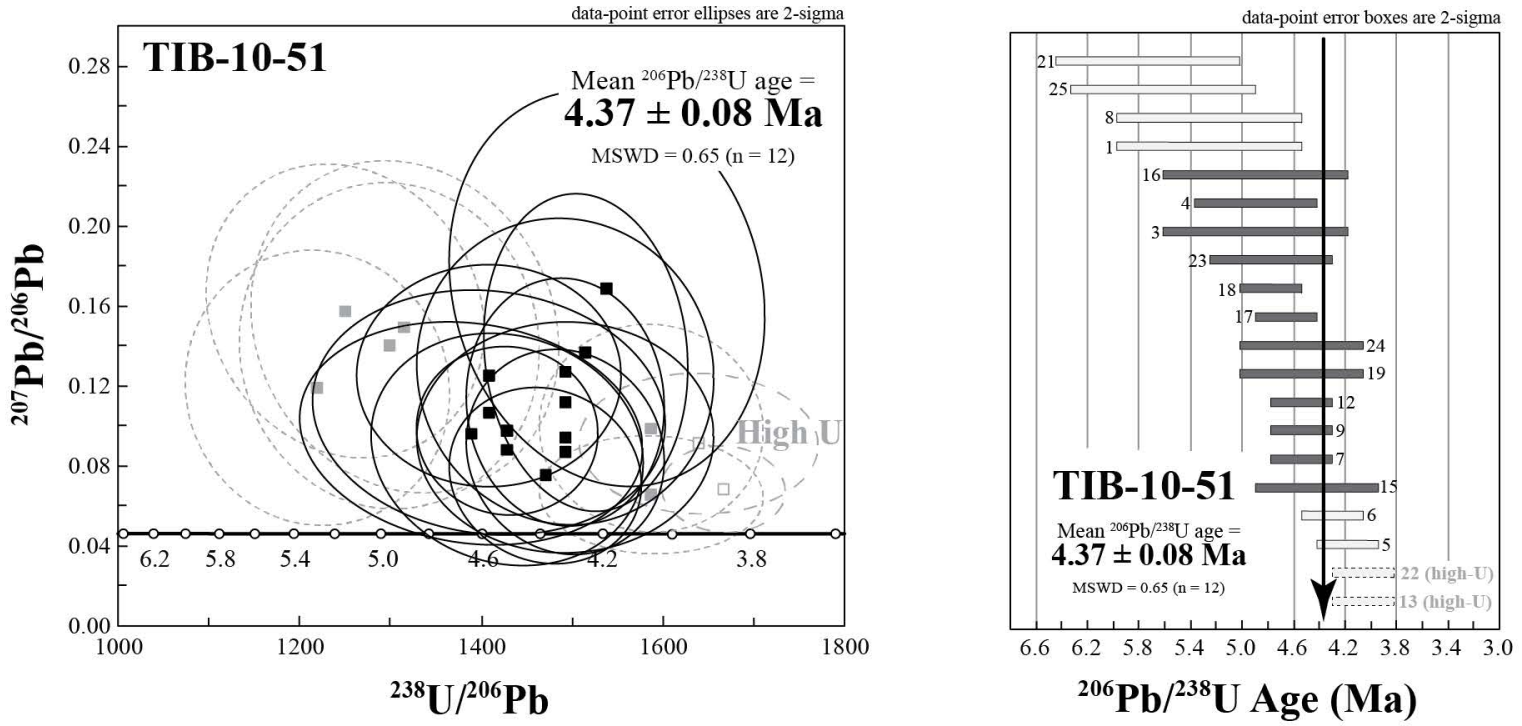


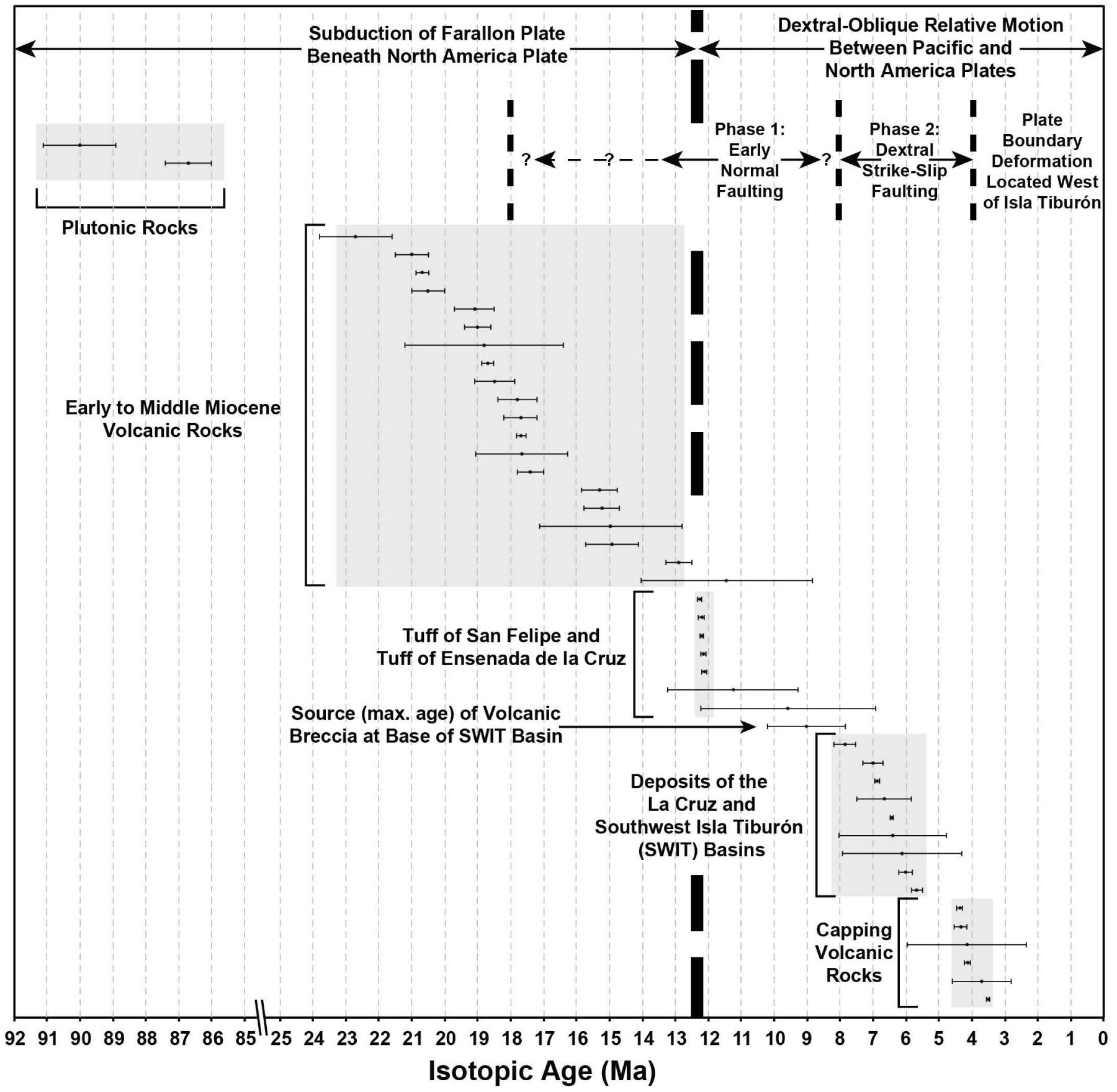


FIGURE 9
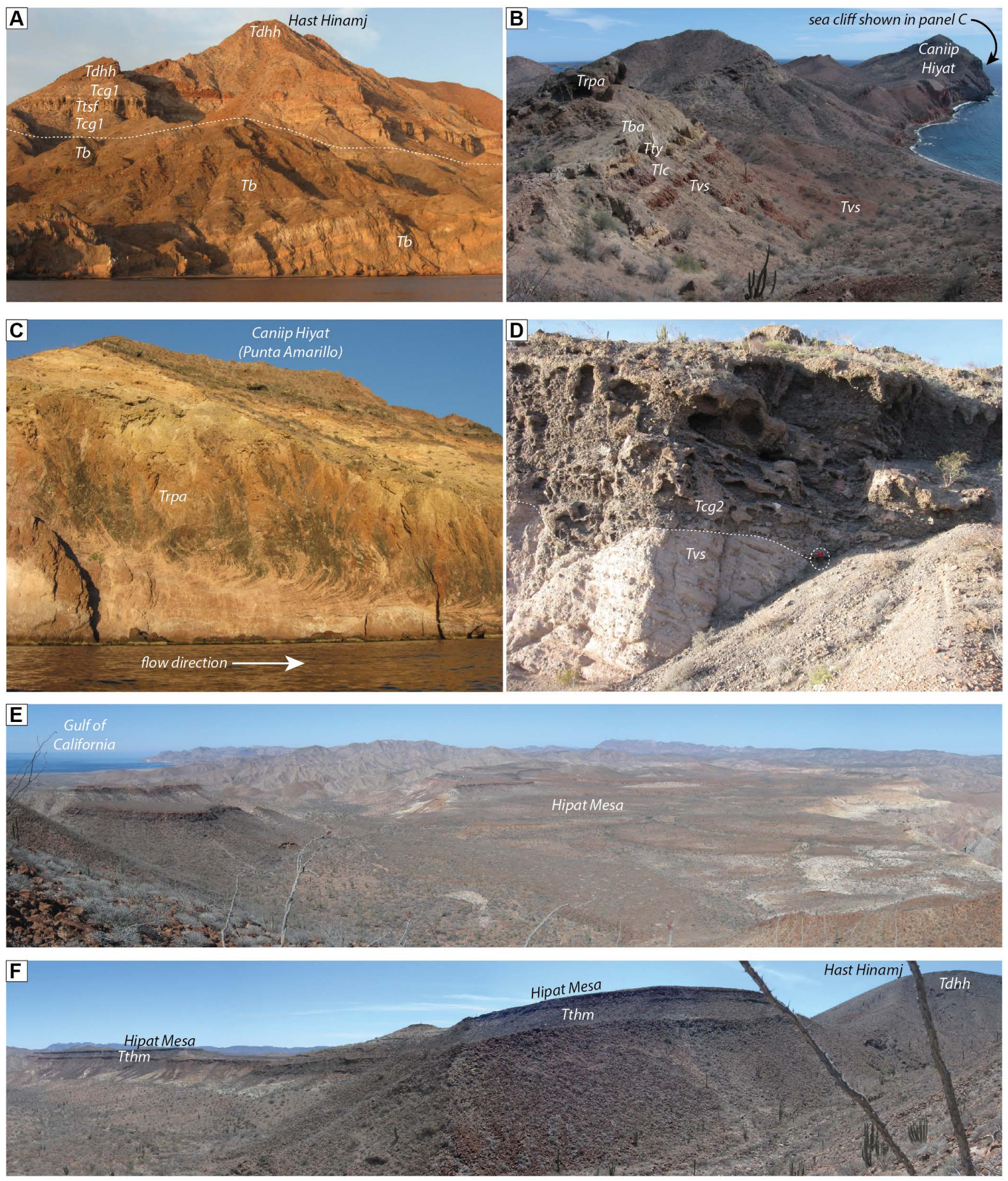


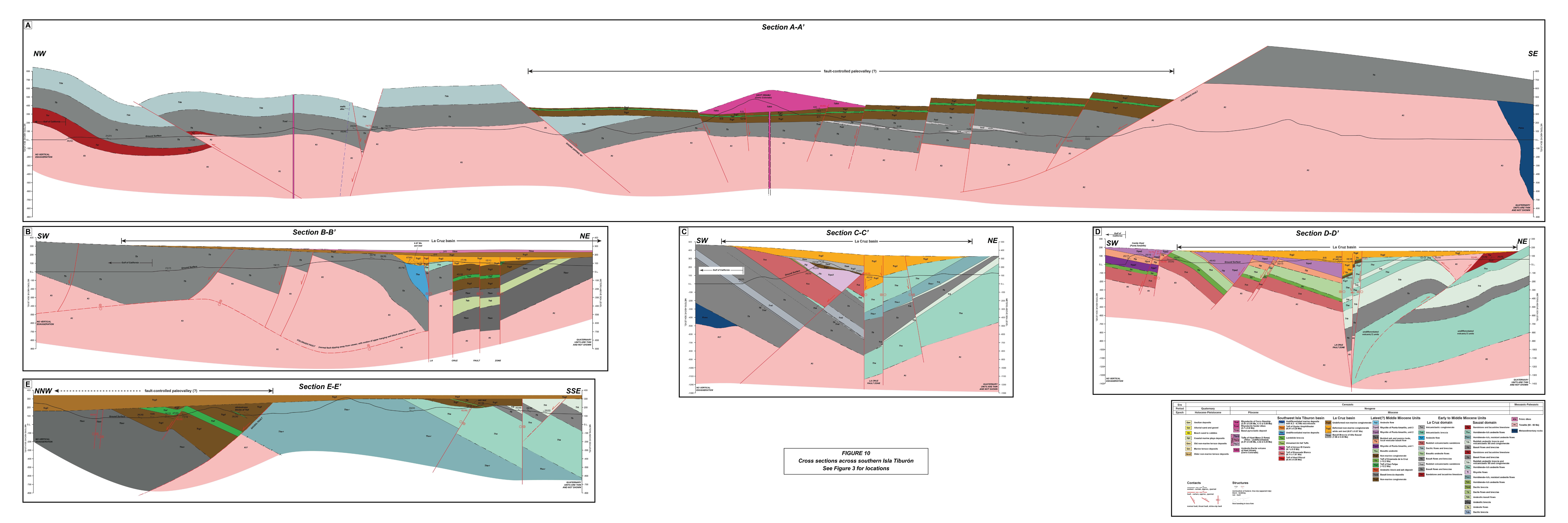




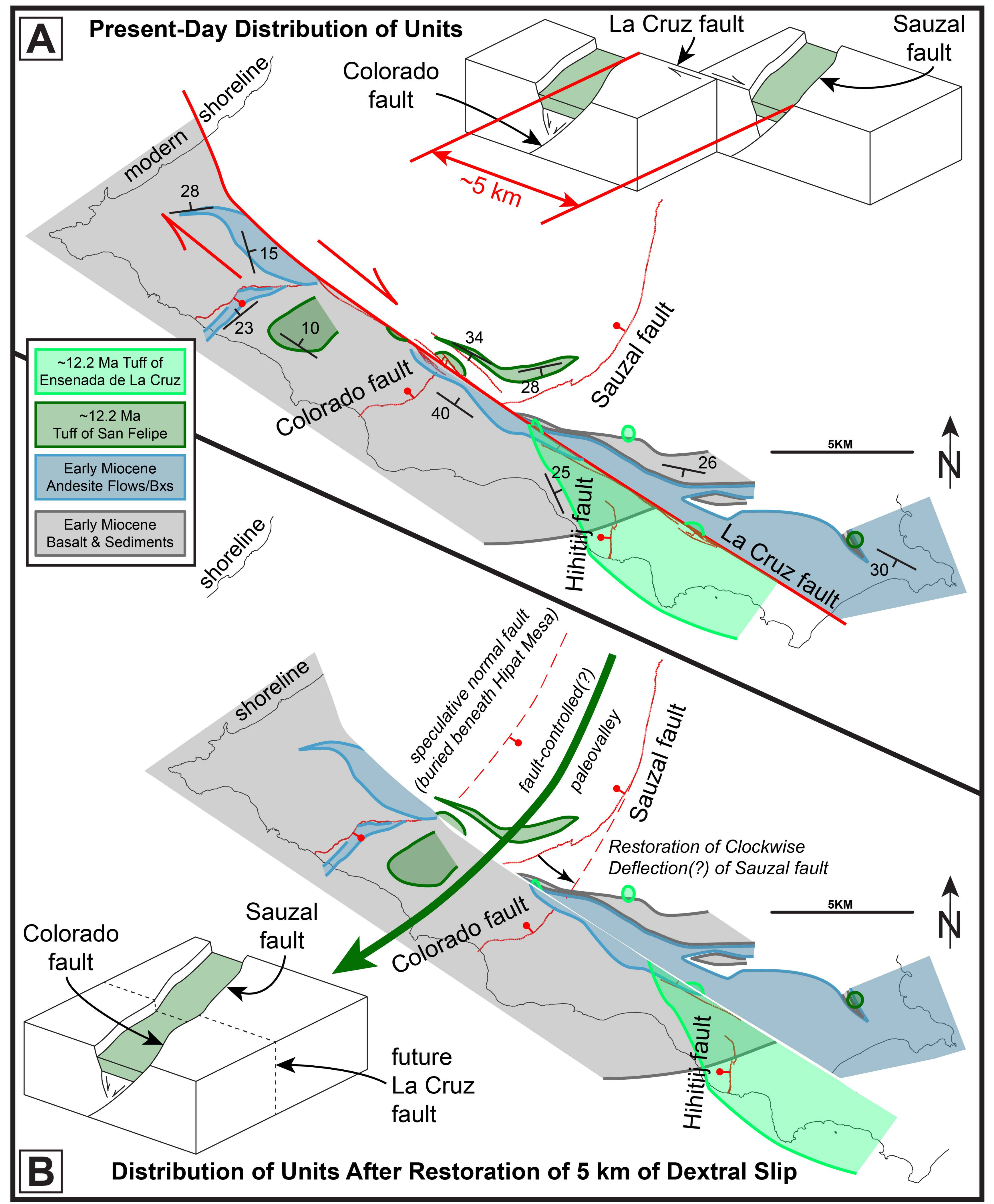

\section{FIGURE 11}

$\sim 12.2 \mathrm{Ma}$ Tuff of Ensenada de La Cruz

$\sim 12.2 \mathrm{Ma}$ Tuff of San Felipe

Early Miocene

Early Miocene Basalt \& Sediments

\section{Restoration of Clockwise \\ Deflection(?) of Sauzal fault}

Colorado

\section{Sauzal} fault colorado future La Cruz fault 


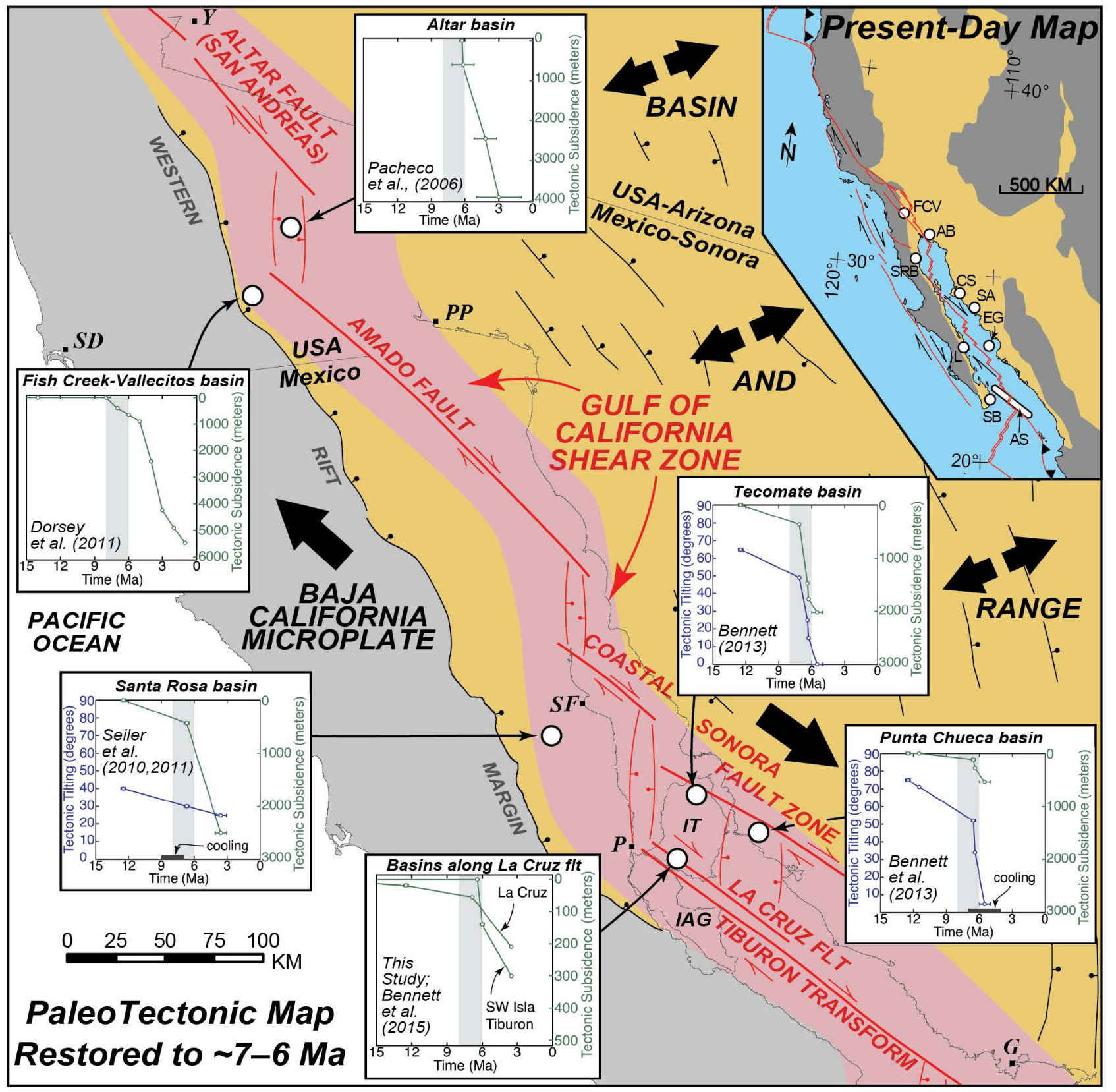


Table 1. ${ }^{40} \mathrm{Ar} /{ }^{39} \mathrm{Ar}$ step-heating data for Isla Tiburón samples.

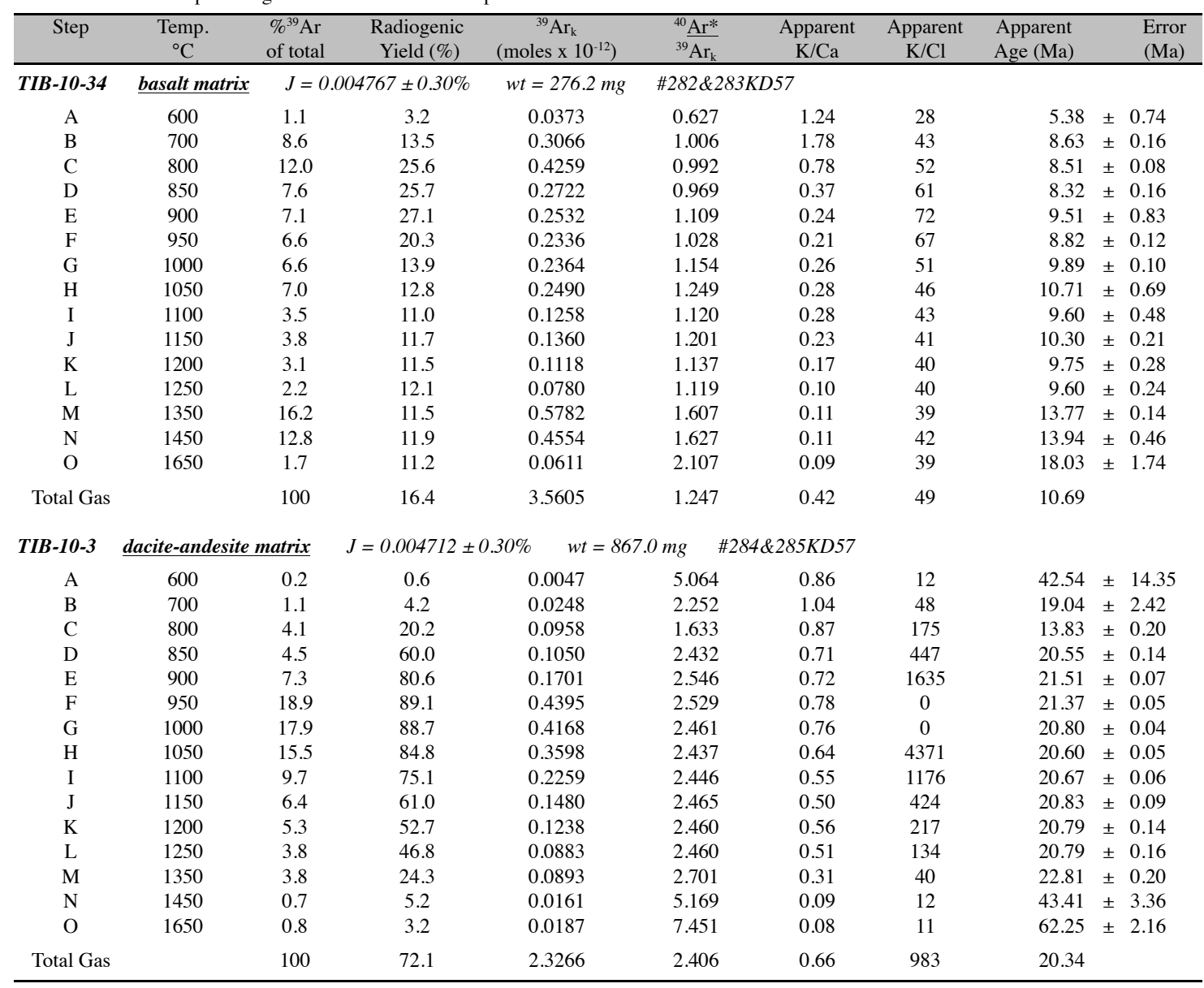

Ages calculated assuming an initial ${ }^{40} \mathrm{Ar} /{ }^{36} \mathrm{Ar}=295.5 \pm 0$.

All precision estimates are at the one sigma level of precision.

Ages of individual steps do not include error in the irradiation parameter $\mathrm{J}$.

No error is calculated for the total gas age. 
Table 2. ${ }^{40} \mathrm{Ar} /{ }^{39} \mathrm{Ar}$ laser total fusion data of single-crystal k-feldspar from volcanic rocks from Isla Tiburón.

\begin{tabular}{|c|c|c|c|c|c|c|c|c|}
\hline $\begin{array}{c}\text { Hole } \\
\text { number }\end{array}$ & $\begin{array}{c}{ }^{39} \mathrm{Ar}_{\mathrm{k}} \\
\text { (Moles) } \\
\end{array}$ & $\begin{array}{c}\text { Radiogenic } \\
\text { Yield }(\%) \\
\end{array}$ & ${ }^{40} \mathrm{Ar}^{*}$ & $\mathrm{~K} / \mathrm{Ca}$ & $\mathrm{K} / \mathrm{Cl}$ & $\begin{array}{r}\text { Age } \\
(\mathrm{Ma}) \\
\end{array}$ & & $\begin{array}{l}\text { Error } \\
(\mathrm{Ma}) \\
\end{array}$ \\
\hline$T I B-10-36 b$ & Sonora, Mexico & sanidine & \multicolumn{2}{|c|}{$J=0.004606 \pm 0.25 \%$} & \#204KD57 & & & \\
\hline 8 & $5.73 \mathrm{E}-14$ & 28.7 & 1.436 & 3.2 & 2632 & 11.89 & \pm & 0.20 \\
\hline 9 & $2.29 \mathrm{E}-14$ & 72.1 & 1.438 & 3.0 & 20000 & 11.91 & \pm & 0.24 \\
\hline 17 & $8.54 \mathrm{E}-14$ & 36.3 & 1.448 & 4.1 & 2174 & 12.00 & \pm & 0.16 \\
\hline 18 & $6.45 \mathrm{E}-14$ & 59.6 & 1.457 & 5.0 & 2778 & 12.06 & \pm & 0.16 \\
\hline 19 & $6.57 \mathrm{E}-14$ & 43.1 & 1.459 & 3.9 & 3704 & 12.09 & \pm & 0.17 \\
\hline 14 & 2.27E-14 & 63.4 & 1.461 & 5.5 & 4762 & 12.10 & \pm & 0.26 \\
\hline 13 & $3.23 \mathrm{E}-14$ & 38.9 & 1.468 & 4.7 & 3571 & 12.15 & \pm & 0.30 \\
\hline 6 & $2.16 \mathrm{E}-14$ & 52.1 & 1.471 & 5.3 & 2439 & 12.19 & \pm & 0.28 \\
\hline 11 & $5.48 \mathrm{E}-14$ & 77.8 & 1.472 & 2.7 & 3571 & 12.19 & \pm & 0.11 \\
\hline 10 & $4.06 \mathrm{E}-14$ & 53.1 & 1.473 & 4.2 & 4348 & 12.20 & \pm & 0.17 \\
\hline 3 & $6.71 \mathrm{E}-14$ & 54.8 & 1.473 & 3.6 & 4762 & 12.20 & \pm & 0.15 \\
\hline 7 & 3.64E-14 & 64.7 & 1.481 & 4.7 & 4545 & 12.26 & \pm & 0.19 \\
\hline 12 & $3.22 \mathrm{E}-14$ & 87.3 & 1.483 & 2.9 & 1724 & 12.28 & \pm & 0.17 \\
\hline 5 & $2.46 \mathrm{E}-14$ & 24.2 & 1.483 & 3.9 & 2041 & 12.28 & \pm & 0.37 \\
\hline 15 & $7.16 \mathrm{E}-14$ & 81.9 & 1.485 & 3.7 & 20000 & 12.30 & \pm & 0.09 \\
\hline 16 & $1.12 \mathrm{E}-13$ & 61.0 & 1.496 & 5.5 & 10000 & 12.39 & \pm & 0.10 \\
\hline 2 & $6.17 \mathrm{E}-14$ & 96.1 & 1.501 & 7.1 & $* * *$ & 12.43 & \pm & 0.09 \\
\hline 1 & $6.97 \mathrm{E}-14$ & 54.3 & 1.510 & 2.3 & 2632 & 12.51 & \pm & 0.15 \\
\hline \multirow[t]{2}{*}{$4 d e l$} & $3.81 E-14$ & 55.5 & 1.529 & 4.5 & 5263 & 12.66 & \pm & 0.19 \\
\hline & & \multicolumn{2}{|l|}{$\mathrm{MSWD}=1.20$} & \multicolumn{2}{|c|}{ Weighted Mean Age = } & 12.26 & \pm & 0.07 \\
\hline$T I B-10-41$ & Sonora, Mexico & sanidine & \multicolumn{2}{|c|}{$J=0.004607 \pm 0.25 \%$} & \#202KD57 & & & \\
\hline 3 & $4.83 \mathrm{E}-14$ & 79.8 & 1.423 & 4.8 & 4348 & 11.78 & \pm & 0.32 \\
\hline 13 & $1.36 \mathrm{E}-13$ & 37.4 & 1.431 & 9.3 & 7692 & 11.85 & \pm & 0.14 \\
\hline 14 & $8.61 \mathrm{E}-14$ & 47.8 & 1.433 & 5.0 & 9091 & 11.87 & \pm & 0.18 \\
\hline 4 & $7.30 \mathrm{E}-14$ & 92.8 & 1.435 & 9.5 & $* * *$ & 11.89 & \pm & 0.24 \\
\hline 8 & $5.54 \mathrm{E}-14$ & 52.9 & 1.446 & 9.6 & $* * *$ & 11.98 & \pm & 0.26 \\
\hline 5 & $3.84 \mathrm{E}-14$ & 65.4 & 1.450 & 5.2 & 7692 & 12.01 & \pm & 0.42 \\
\hline 11 & $1.46 \mathrm{E}-13$ & 44.3 & 1.453 & 5.0 & 5556 & 12.04 & \pm & 0.12 \\
\hline 16 & $1.34 \mathrm{E}-13$ & 61.6 & 1.456 & 6.2 & 9091 & 12.05 & \pm & 0.12 \\
\hline 15 & $8.29 \mathrm{E}-14$ & 80.9 & 1.469 & 3.4 & 5556 & 12.17 & \pm & 0.16 \\
\hline 17 & $9.77 \mathrm{E}-14$ & 34.0 & 1.472 & 6.5 & 2174 & 12.19 & \pm & 0.18 \\
\hline 2 & $1.35 \mathrm{E}-13$ & 89.5 & 1.475 & 8.5 & 50000 & 12.22 & \pm & 0.11 \\
\hline 18 & $6.28 \mathrm{E}-14$ & 28.8 & 1.477 & 4.4 & 2128 & 12.23 & \pm & 0.27 \\
\hline 10 & $1.27 \mathrm{E}-13$ & 70.2 & 1.480 & 5.5 & $* * *$ & 12.25 & \pm & 0.12 \\
\hline 12 & $9.47 \mathrm{E}-14$ & 77.0 & 1.481 & 5.8 & 11111 & 12.27 & \pm & 0.15 \\
\hline 9 & $4.28 \mathrm{E}-14$ & 20.7 & 1.490 & 3.8 & 2564 & 12.34 & \pm & 0.38 \\
\hline 6 & $9.51 \mathrm{E}-14$ & 73.8 & 1.503 & 8.2 & 25000 & 12.44 & \pm & 0.15 \\
\hline \multirow[t]{2}{*}{1} & 8.67E-14 & 71.8 & 1.506 & 9.3 & $* * *$ & 12.47 & \pm & 0.17 \\
\hline & & $\mathrm{MSWD}=1.31$ & \multicolumn{3}{|c|}{ Weighted Mean Age = } & 12.14 & \pm & 0.08 \\
\hline
\end{tabular}


Table 2. ${ }^{40} \mathrm{Ar} /{ }^{39} \mathrm{Ar}$ laser total fusion data of single-crystal k-feldspar from volcanic rocks from Isla Tiburón.

\begin{tabular}{|c|c|c|c|c|c|c|c|c|}
\hline \multirow{2}{*}{$\begin{array}{c}\begin{array}{c}\text { Hole } \\
\text { number }\end{array} \\
\text { TIB-9-12 }\end{array}$} & $\begin{array}{c}{ }^{39} \mathrm{Ar}_{\mathrm{k}} \\
\text { (Moles) } \\
\end{array}$ & $\begin{array}{c}\text { Radiogenic } \\
\text { Yield }(\%) \\
\end{array}$ & 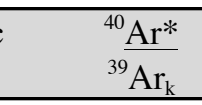 & $\mathrm{K} / \mathrm{Ca}$ & $\mathrm{K} / \mathrm{Cl}$ & \multirow[t]{2}{*}{$\begin{array}{r}\text { Age } \\
(\mathrm{Ma}) \\
\end{array}$} & \multirow{2}{*}{\multicolumn{2}{|c|}{$\begin{array}{l}\text { Error } \\
(\mathrm{Ma}) \\
\end{array}$}} \\
\hline & Sonora, Mexico & sanidine & \multicolumn{2}{|c|}{$J=0.004497 \pm 0.25 \%$} & \#205KD57 & & & \\
\hline $12 \mathrm{del}$ & $1.27 E-13$ & 79.7 & 1.487 & 10.2 & 5882 & 12.02 & \pm & 0.07 \\
\hline 5 & $5.74 \mathrm{E}-14$ & 78.5 & 1.488 & 18.0 & 11111 & 12.03 & \pm & 0.11 \\
\hline 10 & $1.18 \mathrm{E}-13$ & 79.1 & 1.502 & 13.8 & 11111 & 12.15 & \pm & 0.07 \\
\hline 2 & $4.42 \mathrm{E}-14$ & 68.3 & 1.504 & 4.2 & 5882 & 12.16 & \pm & 0.14 \\
\hline 14 & $1.29 \mathrm{E}-13$ & 69.6 & 1.505 & 8.0 & 4762 & 12.16 & \pm & 0.09 \\
\hline 15 & $1.71 \mathrm{E}-13$ & 75.1 & 1.508 & 7.1 & 4167 & 12.19 & \pm & 0.06 \\
\hline 11 & $1.67 \mathrm{E}-13$ & 69.3 & 1.510 & 9.0 & 4762 & 12.21 & \pm & 0.07 \\
\hline 4 & $6.62 \mathrm{E}-14$ & 72.3 & 1.512 & 3.9 & 2273 & 12.22 & \pm & 0.11 \\
\hline 3 & $1.27 \mathrm{E}-13$ & 73.0 & 1.512 & 9.2 & 5000 & 12.23 & \pm & 0.06 \\
\hline 6 & $8.68 \mathrm{E}-14$ & 75.6 & 1.514 & 8.4 & 5556 & 12.24 & \pm & 0.09 \\
\hline 16 & $1.30 \mathrm{E}-13$ & 71.6 & 1.515 & 6.7 & 7692 & 12.25 & \pm & 0.07 \\
\hline 13 & $1.03 \mathrm{E}-13$ & 66.0 & 1.517 & 7.0 & 3226 & 12.26 & \pm & 0.10 \\
\hline 9 & $4.58 \mathrm{E}-14$ & 58.0 & 1.518 & 4.7 & 3571 & 12.27 & \pm & 0.16 \\
\hline 8 & $6.44 \mathrm{E}-14$ & 70.8 & 1.518 & 4.0 & 2564 & 12.28 & \pm & 0.12 \\
\hline ldel & $6.87 E-14$ & 79.0 & 1.540 & 5.8 & 4000 & 12.45 & \pm & 0.10 \\
\hline \multirow[t]{2}{*}{$7 \mathrm{del}$} & $9.09 E-14$ & 33.1 & 1.572 & 4.9 & 2041 & 12.71 & \pm & 0.14 \\
\hline & & \multicolumn{2}{|l|}{$\mathrm{MSWD}=0.41$} & \multicolumn{2}{|c|}{ Weighted Mean Age = } & 12.20 & \pm & 0.05 \\
\hline TIB-10-10 & Sonora, Mexico & sanidine & \multicolumn{2}{|c|}{$J=0.004495 \pm 0.25 \%$} & \#206KD57 & & & \\
\hline $2 d e l$ & $5.33 E-14$ & 54.9 & 1.431 & 4.3 & 9091 & 11.57 & \pm & 0.18 \\
\hline $1 \mathrm{del}$ & $3.54 E-14$ & 45.2 & 1.451 & 3.1 & 4000 & 11.73 & \pm & 0.22 \\
\hline 3 & $3.86 \mathrm{E}-14$ & 52.0 & 1.483 & 4.0 & 4167 & 11.98 & \pm & 0.19 \\
\hline 8 & $4.86 \mathrm{E}-14$ & 43.9 & 1.488 & 4.1 & 7143 & 12.02 & \pm & 0.19 \\
\hline 13 & $6.91 \mathrm{E}-14$ & 46.8 & 1.495 & 4.3 & 33333 & 12.08 & \pm & 0.13 \\
\hline 15 & $8.09 \mathrm{E}-14$ & 61.5 & 1.498 & 4.1 & 11111 & 12.11 & \pm & 0.10 \\
\hline 14 & $5.03 \mathrm{E}-14$ & 46.4 & 1.502 & 4.0 & 2778 & 12.14 & \pm & 0.16 \\
\hline 16 & $3.34 \mathrm{E}-14$ & 52.5 & 1.502 & 0.6 & 3571 & 12.14 & \pm & 0.21 \\
\hline 18 & $3.67 \mathrm{E}-14$ & 50.6 & 1.506 & 4.7 & 5263 & 12.17 & \pm & 0.20 \\
\hline 9 & $4.39 \mathrm{E}-14$ & 37.7 & 1.508 & 4.2 & 4167 & 12.19 & \pm & 0.20 \\
\hline 12 & $4.22 \mathrm{E}-14$ & 35.6 & 1.519 & 1.3 & 3704 & 12.27 & \pm & 0.24 \\
\hline 7 & $5.30 \mathrm{E}-14$ & 75.9 & 1.524 & 3.1 & $* * *$ & 12.31 & \pm & 0.14 \\
\hline 5 & $5.99 \mathrm{E}-14$ & 42.5 & 1.524 & 4.9 & 3125 & 12.32 & \pm & 0.17 \\
\hline 4 & $4.02 \mathrm{E}-14$ & 43.8 & 1.529 & 3.0 & 3704 & 12.36 & \pm & 0.20 \\
\hline 11 & $3.86 \mathrm{E}-14$ & 52.3 & 1.533 & 3.7 & 2857 & 12.39 & \pm & 0.22 \\
\hline 10 & $5.07 \mathrm{E}-14$ & 33.3 & 1.537 & 4.2 & 5000 & 12.42 & \pm & 0.20 \\
\hline \multirow[t]{2}{*}{17} & $5.59 \mathrm{E}-14$ & 51.4 & 1.550 & 4.1 & 1667 & 12.52 & \pm & 0.16 \\
\hline & & \multicolumn{2}{|l|}{ MSWD = 0.85} & \multicolumn{2}{|c|}{ Weighted Mean Age = } & 12.21 & \pm & 0.09 \\
\hline$T I B-10-49$ & Sonora, Mexico & sanidine & \multicolumn{2}{|c|}{$J=0.004498 \pm 0.25 \%$} & \#203KD57 & & & \\
\hline 6 & $5.96 \mathrm{E}-14$ & 23.4 & 1.452 & 8.6 & 2000 & 11.74 & \pm & 0.24 \\
\hline 14 & $4.42 \mathrm{E}-14$ & 53.3 & 1.454 & 8.6 & 2439 & 11.76 & \pm & 0.17 \\
\hline 12 & $9.30 \mathrm{E}-14$ & 34.8 & 1.470 & 6.3 & 3448 & 11.89 & \pm & 0.15 \\
\hline 9 & $3.79 \mathrm{E}-14$ & 55.9 & 1.479 & 5.0 & 3030 & 11.96 & \pm & 0.19 \\
\hline 11 & $5.05 \mathrm{E}-14$ & 69.7 & 1.481 & 6.2 & 6250 & 11.98 & \pm & 0.13 \\
\hline 3 & $4.64 \mathrm{E}-14$ & 46.5 & 1.490 & 4.7 & 2000 & 12.05 & \pm & 0.18 \\
\hline
\end{tabular}


Table 2. ${ }^{40} \mathrm{Ar} /{ }^{39} \mathrm{Ar}$ laser total fusion data of single-crystal k-feldspar from volcanic rocks from Isla Tiburón.

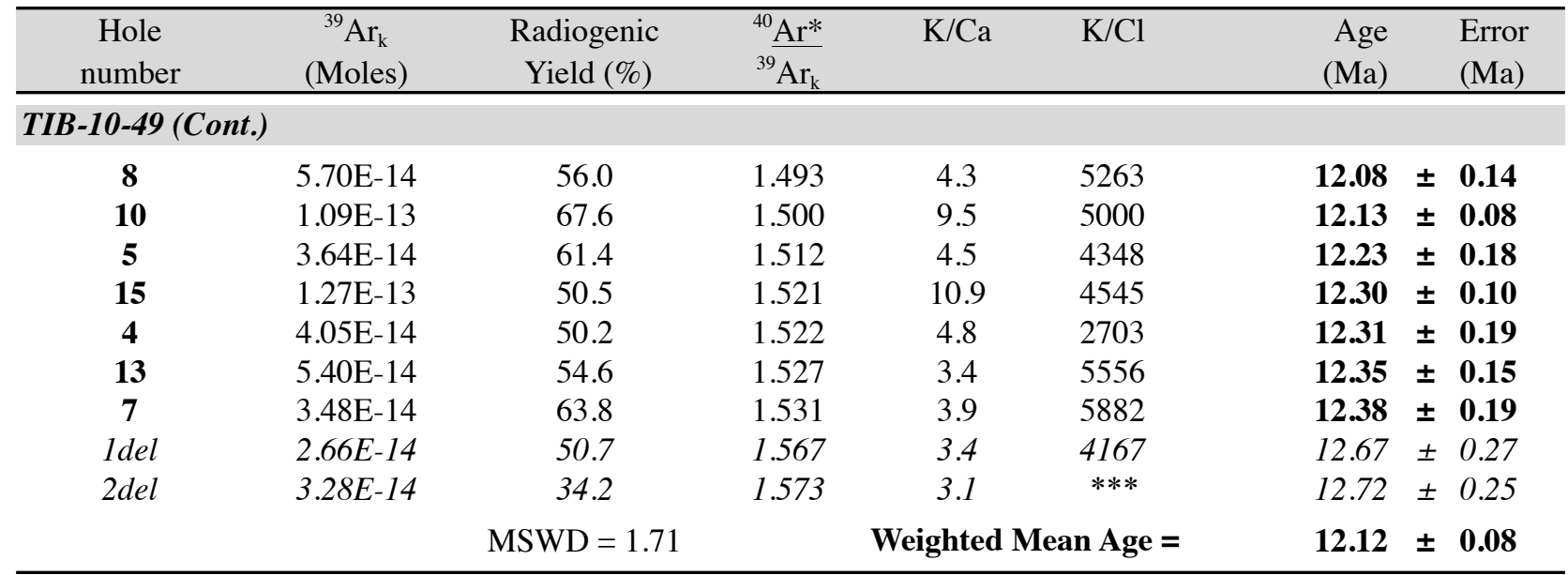

Analyses in gray italics are not used to calculate the weighted mean age 
Table 3. U-Th-Pb analytical data for LA-ICPMS spot analyses on zircon grains for volcanic rocks from Isla Tiburón.

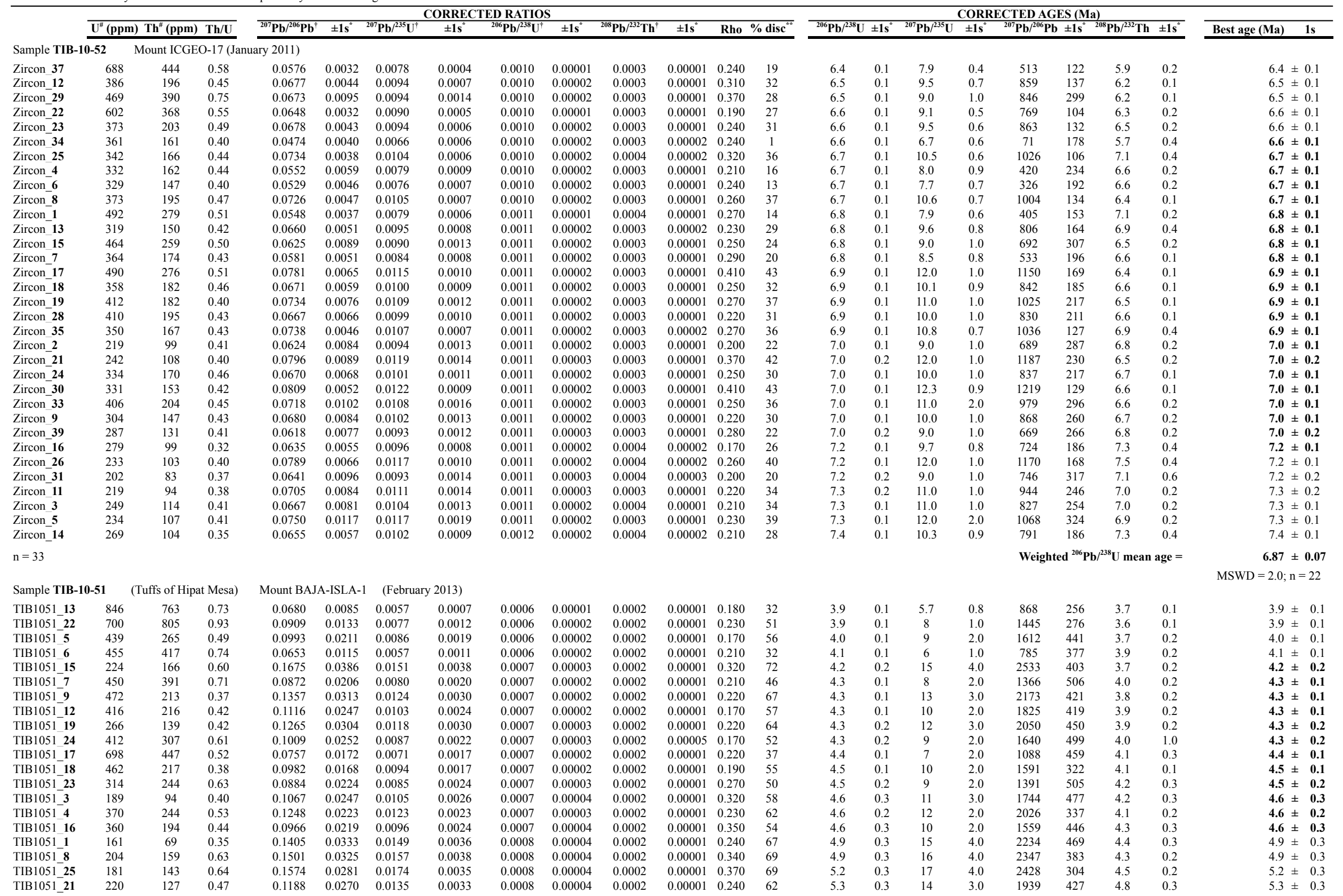




\begin{tabular}{|c|c|c|c|c|c|c|c|c|c|c|c|c|c|c|c|c|c|c|c|c|c|c|}
\hline TIB1051_2 & 267 & 63 & 0.19 & 0.0771 & 0.0111 & 0.0247 & 0.0036 & 0.0023 & 0.00006 & 0.0007 & 0.00002 & 0.170 & 40 & 15.0 & 0.4 & 25 & 4.0 & 1123 & 297 & 14.1 & 0.4 & $15.0 \pm 0.4$ \\
\hline TIB1051_11 & 145 & 99 & 0.55 & 0.0530 & 0.0030 & 0.1197 & 0.0070 & 0.0164 & 0.00020 & 0.0050 & 0.00016 & 0.210 & 9 & 105.0 & 1.0 & 115 & 6.0 & 329 & 125 & 101.0 & 3.0 & $105.0 \pm 1.0$ \\
\hline TIB1051_20 & 488 & 265 & 0.44 & 0.0524 & 0.0014 & 0.1548 & 0.0044 & 0.0214 & 0.00019 & 0.0066 & 0.00017 & 0.310 & 7 & 136.0 & 1.0 & 146 & 4.0 & 304 & 60 & 133.0 & 3.0 & $136.0 \pm 1.0$ \\
\hline TIB1051_14 & 403 & 207 & 0.42 & 0.0527 & 0.0015 & 0.1644 & 0.0049 & 0.0226 & 0.00021 & 0.0072 & 0.00017 & 0.330 & 7 & 144.0 & 1.0 & 155 & 4.0 & 315 & 62 & 144.0 & 3.0 & $144.0 \pm 1.0$ \\
\hline $\mathrm{n}=24$ & & & & & & & & & & & & & & & & & & \multirow{2}{*}{\multicolumn{4}{|c|}{ Weighted ${ }^{206} \mathrm{~Pb} /{ }^{238} \mathrm{U}$ mean age $=$}} & $4.37 \pm 0.08$ \\
\hline & & & & & & & & & & & & & & & & & & & & & & MSWD $=0.65 ; \mathrm{n}=12$ \\
\hline
\end{tabular}

"U and Th concentrations (ppm) are calculated relative to analyses of trace-element glass standard NIST 612.

"Isotopic ratios ratios are corrected relative to PLE standard zircon for mass bias and down-hole fractionation (PLE, Plešovice = 337 Ma; Sláma et al., 2008). Common Pb corrections were made using the Andersen Method (Andersen, 2002).

All errors in isotopic ratios and ages are absolute and given at the 1 -sigma level except for the Weighted Mean ${ }^{20} \mathrm{~Pb} /{ }^{25} \mathrm{U}$ age that is reported at the 2-sigma level.

"Percentage discordance obtained using the following equation $\left(100^{*}\left[\left(\mathrm{age}^{207} \mathrm{~Pb} /{ }^{235} \mathrm{U}\right)-\left(\mathrm{age}^{206} \mathrm{~Pb} /{ }^{235} \mathrm{U}\right)\right] / \mathrm{gge}^{207} \mathrm{~Pb} /{ }^{235} \mathrm{U}\right)$. Positive and negative values indicate normal and inverse discordance, respectively.

Individual zircon ages in bold were used to calculate the weighted mean ${ }^{206} \mathrm{~Pb} / 238 \mathrm{U}$ age and MSWD (Mean Square of Weigthed Deviates) using the computacional program Isoplot (Ludwig, 2003). 
Table 4. Summary of geochronologic ages from southern Isla Tiburón, Sonora, México.

\begin{tabular}{|c|c|c|c|c|c|c|c|c|c|}
\hline \multirow[t]{2}{*}{ Map Unit } & \multirow[t]{2}{*}{ Rock Type } & \multicolumn{2}{|c|}{ Sample Location* } & \multirow{2}{*}{$\begin{array}{l}\text { Sample } \\
\text { Number }\end{array}$} & \multirow[t]{2}{*}{ Technique } & \multirow[t]{2}{*}{ Phase } & \multirow{2}{*}{$\begin{array}{l}\text { Age } \\
\text { (Ma) }\end{array}$} & \multirow{2}{*}{$\begin{array}{l}\text { Age Uncertainty } \\
\text { (Ma) }\end{array}$} & \multirow[t]{2}{*}{ Citation } \\
\hline & & Easting & Northing & & & & & & \\
\hline Tesd & rhyodacite (dike) & 350666 & 3198298 & S2G-13 & $\mathrm{K}-\mathrm{Ar}$ & plagioclase & 3.70 & 0.90 & Gastil and Krummenacher (1977b) \\
\hline Tcsf & rhyodacite & 350096 & 3197359 & TIB-09-06 & $\mathrm{U} / \mathrm{Pb}$ & zircon & 4.13 & 0.09 & Bennett et al. (2015) \\
\hline Tthm & tuff & 351869 & 3199506 & TIB-11-20 & $\mathrm{U} / \mathrm{Pb}$ & zircon & 4.34 & 0.20 & Bennett et al. (2015) \\
\hline Tthm & tuff & 358570 & 3192177 & TIB-10-51 & $\mathrm{U} / \mathrm{Pb}$ & zircon & 4.37 & 0.08 & this study \\
\hline Tthp & rhyolite & 350664 & 3197520 & JN51a & $\mathrm{K}-\mathrm{Ar}$ & feldspar & 5.67 & 0.17 & Neuhaus (1989) \\
\hline Tthp & tuff & 350759 & 3197456 & TIB-09-15 & $\mathrm{Ar} / \mathrm{Ar}$ & $\mathrm{k}$-spar & 6.44 & 0.05 & Bennett et al. (2015) \\
\hline Tthp & tuff & 350665 & 3197529 & SWT-99-28 & $\mathrm{Ar} / \mathrm{Ar}$ & k-spar & 6.67 & 0.83 & Oskin (2002) \\
\hline tuff in $T \operatorname{cg} 2$ & tuff & 358843 & 3190902 & TIB-10-52 & $\mathrm{U} / \mathrm{Pb}$ & zircon & 6.87 & 0.07 & this study \\
\hline Tbas? & basalt & 362236 & 3187872 & S2B-3 & $\mathrm{K}-\mathrm{Ar}$ & whole rock & 7.00 & 0.30 & Gastil and Krummenacher (1977b) \\
\hline Tbas & basalt breccia & 363610 & 3186984 & TIB-10-34 & $\mathrm{Ar} / \mathrm{Ar}$ & matrix & 7.86 & 0.33 & this study \\
\hline Tbx & landslide breccia & 351658 & 3197221 & 5 & $\mathrm{Ar} / \mathrm{Ar}$ & plagioclase & 9.02 & 1.18 & Gastil et al. (1999) \\
\hline Ttsf & welded tuff & 354617 & 3191273 & TIB-98-25 & $\mathrm{Ar} / \mathrm{Ar}$ & k-spar & 9.58 & 2.66 & Oskin (2002) \\
\hline Ttsf & welded tuff & 353451 & 3191949 & TIB-09-12 & $\mathrm{Ar} / \mathrm{Ar}$ & k-spar & 12.20 & 0.05 & this study \\
\hline Tlc & welded tuff & 368057 & 3182575 & TIB-10-10 & $\mathrm{Ar} / \mathrm{Ar}$ & k-spar & 12.21 & 0.09 & this study \\
\hline Tlc & welded tuff & 368720 & 3184514 & TIB-10-36B & $\mathrm{Ar} / \mathrm{Ar}$ & k-spar & 12.26 & 0.07 & this study \\
\hline Tbxv & andesitic breccia & 352090 & 3197222 & 83BSJ260 & $\mathrm{K}-\mathrm{Ar}$ & $\mathrm{n} / \mathrm{a}$ & 12.90 & 0.40 & Smith et al. (1985) \\
\hline Tvc & volcaniclastic congl. & 349503 & 3197770 & JN216B & $\mathrm{K}-\mathrm{Ar}$ & whole rock & 14.92 & 0.80 & Neuhaus (1989) \\
\hline $\mathrm{Tb}$ & andesite & 350070 & 3196191 & JN219 & $\mathrm{K}-\mathrm{Ar}$ & whole rock & 14.96 & 2.17 & Neuhaus (1989) \\
\hline Tba & andesitic basalt & 351116 & 3196133 & JN272 & K-Ar & feldspar & 15.24 & 0.54 & Neuhaus (1989) \\
\hline $\mathrm{Tb}$ & basalt & 349090 & 3195572 & JN106 & $\mathrm{K}-\mathrm{Ar}$ & whole rock & 15.30 & 0.54 & Neuhaus (1989) \\
\hline Tba & latite & 353466 & 3194261 & JN237 & $\mathrm{K}-\mathrm{Ar}$ & feldspar & 17.40 & 0.40 & Neuhaus (1989) \\
\hline $\mathrm{Tb}$ & basalt & 348878 & 3196649 & JN223 & $\mathrm{K}-\mathrm{Ar}$ & whole rock & 17.67 & 1.40 & Neuhaus (1989) \\
\hline Tbxv & andesitic breccia & 352715 & 3196721 & 284 & $\mathrm{Ar} / \mathrm{Ar}$ & hornblende & 17.68 & 0.15 & Gastil et al. (1999) \\
\hline Tba & basalt & 352357 & 3195912 & $\mathrm{JN} 252$ & $\mathrm{~K}-\mathrm{Ar}$ & feldspar & 17.70 & 0.50 & Neuhaus (1989) \\
\hline Tba & basalt & 352000 & 3196056 & JN145 & $\mathrm{K}-\mathrm{Ar}$ & feldspar & 17.80 & 0.60 & Neuhaus (1989) \\
\hline $\mathrm{Tb}$ & basalt & 348652 & 3193954 & JN274 & $\mathrm{K}-\mathrm{Ar}$ & whole rock & 18.52 & 0.60 & Neuhaus (1989) \\
\hline Tbxv & andesitic breccia & 352090 & 3197222 & TIB-0917 & $\mathrm{U} / \mathrm{Pb}$ & zircon & 18.70 & 0.19 & Bennett et al. (2015) \\
\hline
\end{tabular}

* Coordinates are in WGS84 Datium and UTM Zone 12N projection 